\title{
Mineralogical-chemical Alteration and Origin of Ignimbritic Stones Used in the Old Cathedral of Nostra Signora di Castro (Sardinia, Italy)
}

\section{Stefano Columbu, Anna Gioncada, Marco Lezzerini \& Fabio Sitzia}

To cite this article: Stefano Columbu, Anna Gioncada, Marco Lezzerini \& Fabio Sitzia (2019) Mineralogical-chemical Alteration and Origin of Ignimbritic Stones Used in the Old Cathedral of Nostra Signora di Castro (Sardinia, Italy), Studies in Conservation, 64:7, 397-422, DOI: 10.1080/00393630.2018.1565016

To link to this article: https://doi.org/10.1080/00393630.2018.1565016

Published online: 18 Mar 2019.

Submit your article to this journal $\square$

山 Article views: 83

Q View related articles $\sqsubset$

View Crossmark data

Citing articles: 3 View citing articles $[7$ 


\title{
Mineralogical-chemical Alteration and Origin of Ignimbritic Stones Used in the Old Cathedral of Nostra Signora di Castro (Sardinia, Italy)
}

\author{
Stefano Columbu ${ }^{1}$, Anna Gioncada (D) $^{2}$, Marco Lezzerini ${ }^{2}$ and Fabio Sitzia ${ }^{1}$ \\ ${ }^{1}$ Department of Chemical and Geological Sciences, University of Cagliari, Cittadella Universitaria di Monserrato, Cagliari, Italy; ${ }^{2}$ Department \\ of Earth Sciences, University of Pisa, Pisa, Italy
}

\begin{abstract}
The pyroclastic rocks belonging to the Late Eocene-Miocene volcanic activity that occurred in Sardinia between 38 and 15 Ma ago were widely used as construction materials in several Romanesque churches of the easternmost Logudoro area, as well as in large parts of the Sardinia territory. In this work, the ancient Cathedral of Nostra Signora di Castro (twelfth century) was taken as a representative case study. There is no historical or archaeological evidence of ancient quarries. Based on the geochemical, petrographic, and volcanological data on several samples from an extensive field area (approximately $150 \mathrm{~km}^{2}$ ), a geographical zoning of the volcanics has been recognised. In the Oschiri sector, there are three different sub-zones, which can be identified with different volcanic rocks: less fractionated rocks (Differentation Index $\sim 70-78$ ); intermediately fractionated rocks (D.I. $\sim 76-$ 79); and more fractionated rocks (D.I. 77-82). To identify the origin of the ignimbrite rocks of the Church of Nostra Signora di Castro, two statistical methods were used: stepwise linear discriminant and canonical analysis. Moreover, to define the geochemical transformation processes induced by the alteration, a comparative study of concentrations of major and trace elements measured by XRF and SEM-EDX analyses on the surface portion and the innermost areas of the stone was made.
\end{abstract}

ARTICLE HISTORY

Received August 2018

Accepted December 2018

\section{KEYWORDS}

Provenance; XRF; XRD; SEMEDX; petrographic study; medieval church; Logudoro; Romanesque

\section{Introduction and aims}

The Church of Nostra Signora di Castro was built in the territory of Oschiri on the Logudoro area (northern Sardinia; Figures 1 and 2(a,b)). It was consecrated in the year 1174, and it was once the cathedral of the diocese of Castro (Spano 1858) merged in 1503 with the diocese of Ottana and Bisarcio. The Church of Nostra Signora di Castro is one of the smallest Sardinian Romanesque cathedrals, but it represents one the most beautiful Romanesque churches located in rural areas. It is located on the site of the ancient Roman fortified military centre of Lugudonec, mentioned in the Itinerarium Antonini. The diocese had a populated and vital territory during the twelfth century, but already in 1220 the diocesan appears to be impoverished. The documentary sources highlight that by the year 1420 the site was abandoned, although the Church of Nostra Signora di Castro still remained in use for a long time, least every once in a while (Serra and Coroneo 2004).

The modest size of the Church of Nostra Signora di Castro seems to be unusual for a cathedral, especially if compared to other coeval cathedrals in the same Giudicato of Torres. However, its historical-cultural importance is evident in technical and formal aspects such as the care in the cutting and placing of the ashlars in the wall surface (Serra and Coroneo 2004). Along the northern side abuts a porch, built later. The cathedral became the prototype of several other churches built in the territory of Oschiri and dating before 1174: S. Demetrio, located inside the Oschiri village (Figure 2(c, d)) and already consecrated in 1168; Santa Maria di Otti, located inside the ancient village of Otti (before Octi, Figure 2(e, f)); and S. Maria di Tula, already existing in 1176.

The Church of Nostra Signora di Castro (Figure 2(a, b)) was built with different kinds of local ignimbritic rocks of Late Eocene-Miocene volcanic phase (Beccaluva et al. 2011; Lustrino, Duggen, and Rosenberg 2011), whose products occur on vast outcrops (Figures 1 and 3) on several sectors of Sardinia (Figure 1). The ignimbrites were frequently used together with other rocks and ancient mortars to build several historical monuments in the Middle Ages (Figure 2) as well as in the other ancient periods (Coroneo 1993; Cruciani et al. 2010; Verdiani and Columbu 2010; Columbu and Verdiani 2014; Antonelli, Columbu, De Vos Raaijmakers, et al. 2014; Antonelli, Columbu, Lezzerini, et al. 2014; Columbu et al. 2014; Chiarelli et al. 2015; Di Benedetto et al. 2015; Miriello et al. 2015; Columbu, Sitzia, and Verdiani 2015; Columbu, Cruciani, et al. 2015; Columbu and Garau 2017; Columbu, Lisci, Sitzia, and Buccellato, et al.

CONTACT Stefano Columbu columbus@unica.it Department of Chemical and Geological Sciences, University of Cagliari, Cittadella Universitaria di Monserrato, Va Trentino 51, Cagliari, CA 09134 Italy 


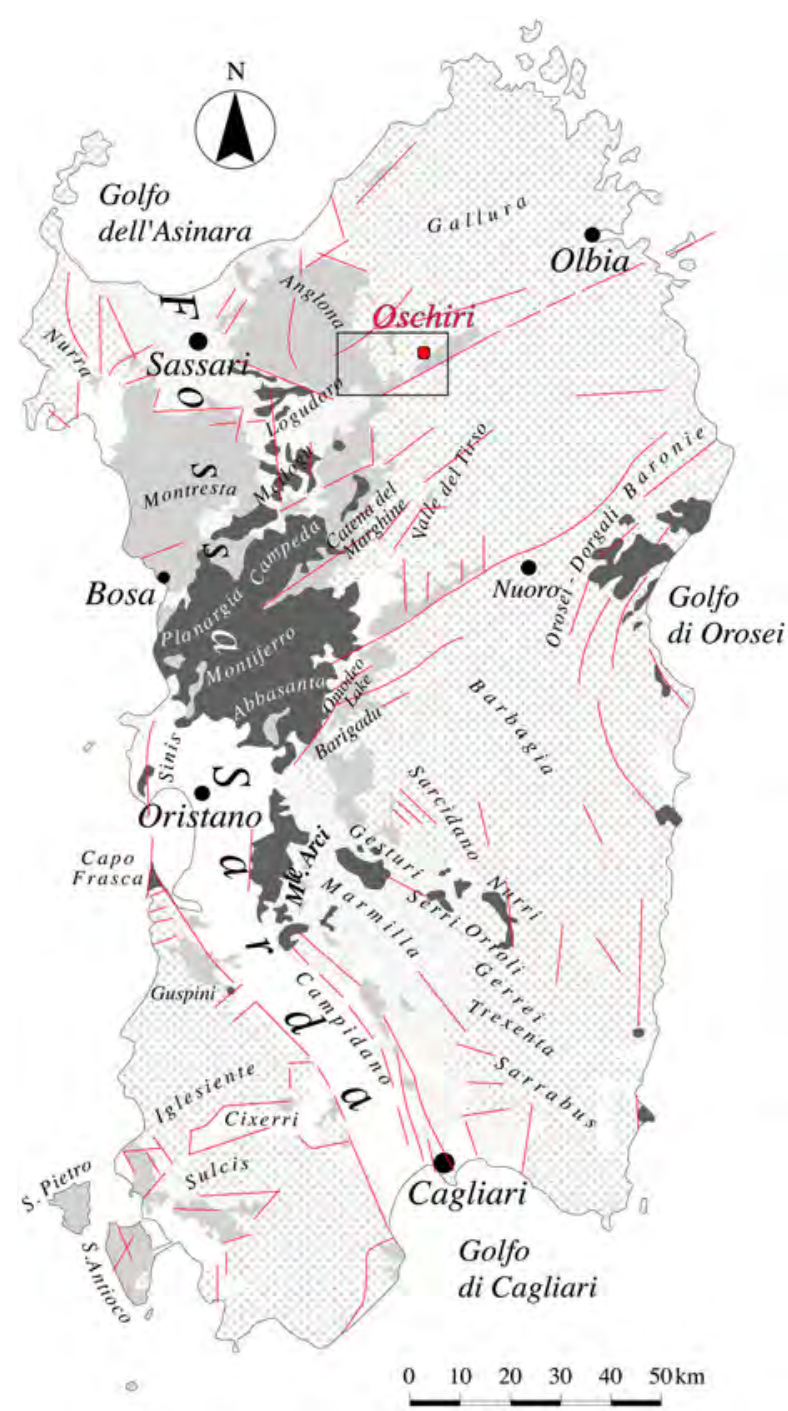

Figure 1. Schematic geological map of Sardinia with the localisation of the Oschiri village and sector reported on the sketch map of Figure 3. Legend of patterns and colours refer to lithologies: white $=$ recent alluvial sediments; light grey $=$ OligoMiocene volcanics including the Oschiri ignimbrites; dark grey = Plio-Pleistocene volcanics; stippled grey=Miocene marine sediments; grey crosses $=$ Paleozoic crystalline basement and Mesozoic formations; and red continuous and dashed lines $=$ faults.

2017; Columbu, Sitzia, and Ennas 2017; Raneri et al. 2018; Columbu, Antonelli, and Sitzia 2018; Columbu, Piras, et al. 2018; Columbu, Palomba, et al. 2018; Columbu, Lisci, Sitzia, Lorenzetti, et al. 2018; Columbu, Garau, and Lugliè 2018; Manzoni et al. 2019).

The ignimbritic rocks probably belong to the local outcrops, but considering the geochemical variety of volcanics, it is not easy to find their exact origin. Moreover, no evidence exists of ancient quarries and it is probable that there were contemporaneous different procurement points of geomaterials in the field, or the use of stone boulders.

The volcanic rocks used to build the Church of Nostra Signora di Castro, especially when pyroclastic facies were used, show frequently a physical decay and a mineralogical-chemical alteration. In several
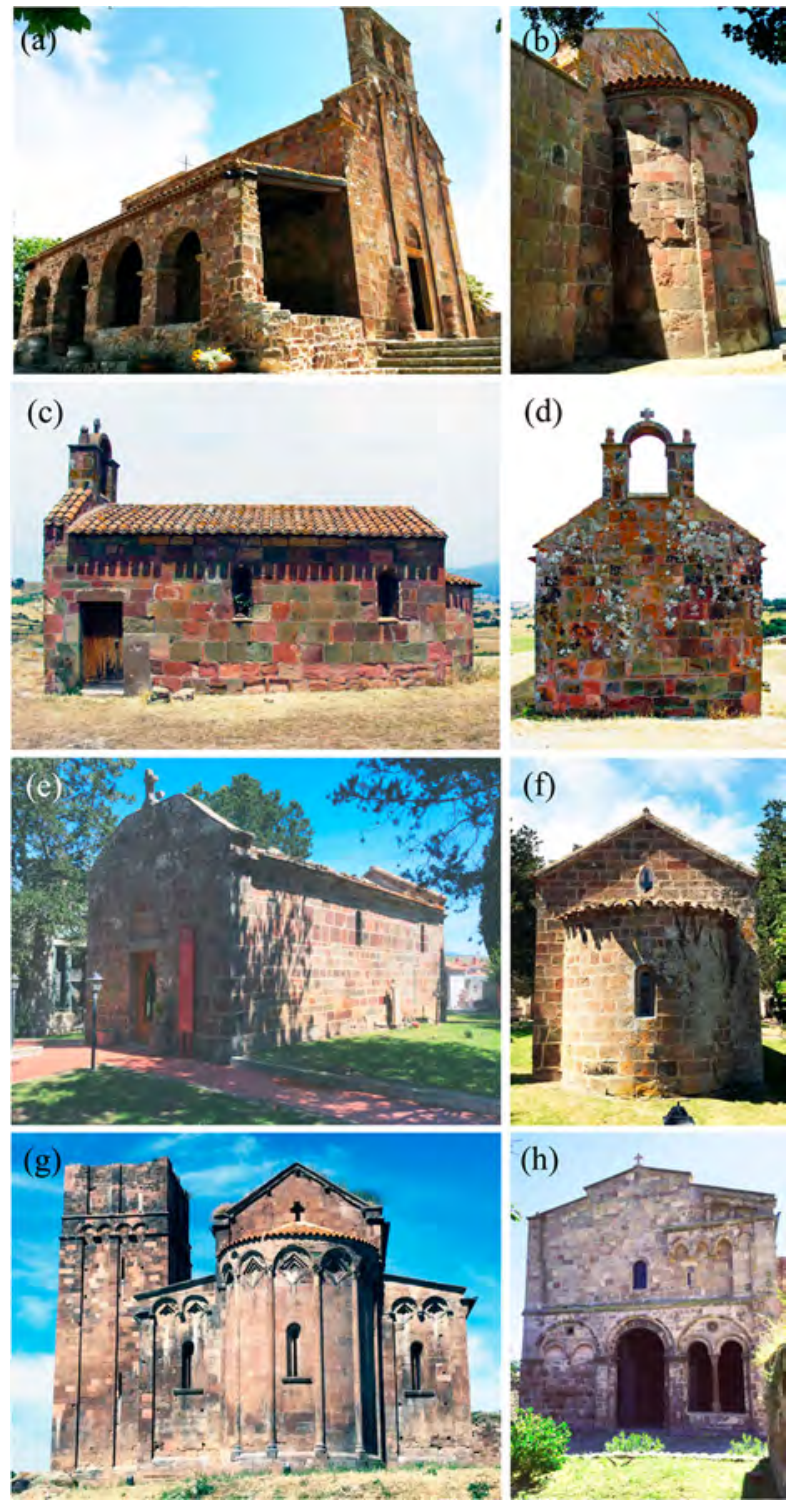

Figure 2. Old Cathedral of Nostra Signora di Castro (Oschiri) and other important medieval Romanesque churches: $(a, b)$ main facade and apse of Castro Church, respectively; (c, d) Santa Maria di Otti Church (south of Castro Church); (e, f) San Demetrio Church, located within the cemetery of Oschiri village; and $(\mathrm{g}, \mathrm{h})$ Basilica of Sant'Antioco di Bisarcio, located in the field of Ozieri.

papers, the stone decay has been investigated, especially studying sandstone, limestone, or other rocks (Rodriguez-Navarro et al. 1997; Sabatini et al. 2000; Bargossi, Felli, and Guerriri 2002; Franzini et al. 2007; Benavente, Cultrone, and Gómez-Heras 2008; Sebastian et al. 2008; Wangler and Scherer 2008; Leoni et al. 2010; Gioncada et al. 2011; López-Doncel et al. 2013; Lezzerini et al. 2016; Lezzerini et al. 2018; Ramacciotti et al. 2018), but research on Sardinian pyroclastic rocks is still scarce, despite their wide use in ancient times (Coroneo 1993).

The main aim of this research was to determine the minero-petrographic and geochemical characteristics of volcanic rocks used in the Church of Nostra Signora di Castro, in order to identify the origin of the geomaterials, 


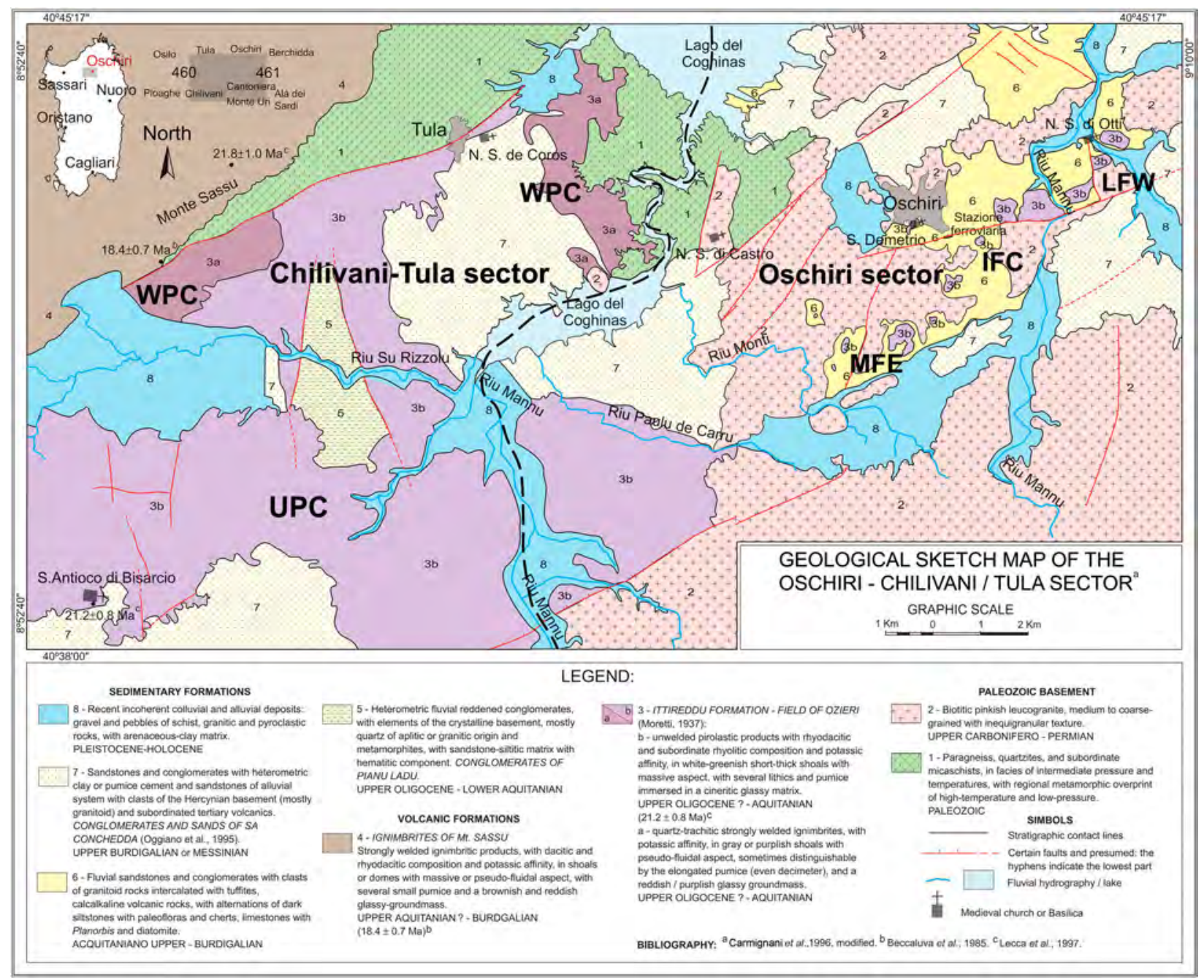

Figure 3. Geological sketch map of Oschiri-Chilivani/Tula sector where are located the medieval churches of Castro Cathedral, Santa Maria di Otti, and San Demetrio churches, and Basilica Sant'Antioco di Bisarcio (Ozieri territory). The geological map has been set according to geopetrographic surveys performed in this work, according to Beccaluva et al. (1985), Carmignani et al. (1996), and Lecca et al. (1997).

providing geological samples for any restoration intervention on the monument and to deepen knowledge of the ancient trade of raw materials in the Middle Ages.

A detailed petrographic and geochemical comparison of ignimbritic rocks from the Church of Nostra Signora di Castro and the volcanic outcrops belonging to the Oschiri and Chilivani/Tula areas around the Church was made, using the geochemical XRF data collected by Columbu (2017). The purpose of the work was also to define the physical and chemical factors in the decay processes of these ignimbrites. To study the chemical alteration of the samples from the Church of Nostra Signora di Castro, a comparative study of concentrations of major and trace elements measured by XRF analysis in the surface portion $\left(A^{+}\right)$ and in the innermost of the stone $\left(A^{-}\right)$was made.

The study of the chemical-physical alteration of geomaterials used in cultural heritage allows first of all an understanding of the causes and mechanisms of decay processes that occurred in the monument. Furthermore, the definition of the origin of geomaterials is important and significant not only from an archaeological historical point of view (to know the ancient trade of building materials in historical times), but also to intervene in the restoration of monuments with the substitution, or partial integration, of the degraded decorative elements or ashlars of monuments.

\section{Material and methods}

A sampling of stones from the Church of Nostra Signora di Castro refers exclusively to the building material taken from the exterior façades. Seventy-five samples come from ashlars of the ancient building and they represent all the volcanic lithotypes as for orientation (N-S-E-W), height above the surrounding countryside, and different alteration degrees. As little material as possible in the form of splinters was removed, still attaining our dual goal of sampling the innermost part $\left(A^{-}\right)$and the outermost one $\left(A^{+}\right)$, as well as having enough material for the required petrographic and chemical analyses. $\mathrm{A}^{-}$and $\mathrm{A}^{+}$specimens were analysed only for a total of 29 samples out of 79 . 
Two hundred and twenty rock samples from the Oschiri area and nearby outcrops (previously studied by Columbu (2017)) were used to define the geological provenance of the ignimbrites used for building the Church of Nostra Signora di Castro. In the same way as the samples from the Church, $\mathrm{A}^{-}$and $\mathrm{A}^{+}$specimens were analysed only for a total of 27 samples out of 220 .

Uncovered thin sections, oriented parallel and orthogonal to the flow planes (i.e. magmatic foliation) of the volcanic rocks, were prepared for optical microscope observations of the mineralogical and petrographic characteristics. Selected thin sections were subsequently polished and carbon-coated for SEMEDX investigations. Also, small fragments of the ashlars were attached to aluminium sample holders and carbon-coated. SEM-EDX instrumentation was a Philips XL30 with Genesis EDS.

Whole-rock chemistry of all samples was determined on selected portions (avoiding the larger miarolitic cavities) by XRF with a Philips PW1400 spectrometer using an Rh-tube for the analysis of both major elements and some trace elements ( $R b$, $\mathrm{Sr}, \mathrm{Pb}, \mathrm{Zn}, \mathrm{Y}, \mathrm{Nb}$, and $\mathrm{Zr}$ ), and a W-tube for the analysis of the elements $\mathrm{Ni}, \mathrm{Cr}, \mathrm{Ba}, \mathrm{V}, \mathrm{La}$, and $\mathrm{Ce}$. The analyses were carried out on pressed-rock powders as suggested by Franzini, Leoni, and Saitta (1972). The measurement accuracy is $\pm 1 \%$ for $\mathrm{SiO}_{2}, \mathrm{TiO}_{2}, \mathrm{Al}_{2} \mathrm{O}_{3}$, $\mathrm{Fe}_{2} \mathrm{O}_{3}, \mathrm{CaO}, \mathrm{K}_{2} \mathrm{O}$, and $\mathrm{MnO}$ and $\pm 4 \%$ for $\mathrm{MgO}, \mathrm{Na}_{2} \mathrm{O}$, and $\mathrm{P}_{2} \mathrm{O}_{5}$; the accuracy of trace elements is $\pm 2-3 \%$ to $1000 \mathrm{ppm} ; \pm 5-10 \%$ at $100 \mathrm{ppm}$, and $\pm 10-20 \%$ to 10 ppm (Wangler and Scherer 2008; Columbu 2017). The amount of volatile components was determined by calculating the loss in weight $\%$ at $1000^{\circ} \mathrm{C}$ on powders dried at $105 \pm 5^{\circ} \mathrm{C}$ until constant weight is reached (L.O.I., Loss On Ignition). The $\mathrm{FeO}$ was determined by volumetric titolation with $\mathrm{KMnO}_{4} 10 \mathrm{~N}$ in acid solution.

Whole rock powders were analysed by X-ray diffraction (XRD) with a PAN-ANALYTICAL diffractometer (anticathode $\mathrm{Cu}$, tube voltage of $40 \mathrm{kV}$ and current intensity of $30 \mathrm{~mA}$ ) with an X-Celerator proportional counter. The identification of clay minerals was determined on oriented and $\mathrm{Mg}^{2+}-\mathrm{K}^{+}$saturated aggregates of the $<2 \mu \mathrm{m}$ fraction. $\mathrm{Mg}^{2+}$ saturated specimens were scanned both in the air-dried and glycolated states. For some selected $\mathrm{Mg}^{2+}$ saturated specimens, glycerol treatment was also performed. $\mathrm{K}^{+}$saturated mounts were run at room temperature as well as after heating at 100,300 , and $550^{\circ} \mathrm{C}$.

\section{Geological setting of the Chilivani- Berchidda Basin}

\section{Cenozoic Sardinian volcanism}

The Oschiri area (Figure 1), where the Church of Nostra Signora di Castro is located, belongs to the Chilivani-
Berchidda Basin (Oggiano, Pasci, and Funedda 1995), in Eastern Logudoro (Figure 3). The basin is an offshoot of an Oligo-Miocene complex tectonic structure, trending N-S, known as the 'Fossa tettonica sarda' (Vardabasso and Atzeni 1962) (Figure 1) or 'Rift of Sardinia' (Cherchi and Montadert 1982). This latter is a large tectonic low (Coulon 1977; Cherchi and Montadert 1982; Dostal, Coulon, and Dupuy 1982; Advokaat et al. 2014), where, as in other areas of Sardinia, intense igneous activity occurred. It is generally related to an $\mathrm{N}$ NW deeping subduction of the Ionian oceanic lithosphere which developed (probably since Middle-Late Eocene) beneath the Paleo-European-Iberian continental margin which led, during the Oligocene, to the formation of the rift between Sardinia and Provence (Burrus 1984; Beccaluva et al. 1989; Beccaluva, Bianchini, Coltorti, et al. 2005; Cherchi et al. 2008; Beccaluva et al. 2011).

The pyroclastic rocks used for the old Castro Cathedral belong to the first phase of Cainozoic Sardinian volcanism (Beccaluva et al. 1989; Beccaluva, Bianchini, Coltorti, et al. 2005; Beccaluva, Bianchini, Bonadiman, et al. 2005; Beccaluva et al. 2011; Lustrino, Duggen, and Rosenberg 2011), characterised by orogenic magmatic activity developed mostly during Late EoceneMiocene times ( 38-15 Ma). The major and trace element indicators and $\mathrm{Sr}-\mathrm{Nd}-\mathrm{Pb}-\mathrm{Hf}-\mathrm{Os}-\mathrm{O}$ isotopes highlight complex petrogenetic processes including subduction-related metasomatism, hybridisation of the mantle and crustal melts, variable degrees of crustal contamination, and fractional crystallization at shallow depths (Lustrino et al. 2013).

The Sardinian orogenic magmatism starts in the north of the island in Calabona area (N Sardinia, 38 Ma (Lustrino et al. 2009)) with a small microdiorite outcrop, and it follows in Alghero (32.3 $\pm 1.5 \mathrm{Ma}$ (Montigny, Edel, and Thuizat 1981)); (27.6 $\pm 1.5 \mathrm{Ma}$ (Giraud, Bellon, and Turco 1979)) and Osilo (31.2 $\pm 1.1 \mathrm{Ma}$ (Montigny, Edel, and Thuizat 1981)), and contemporaneously in the south of island in the Cixerri area (30.2 $\pm 0.9 \mathrm{Ma}$ (Beccaluva et al. 1985); $28.3 \pm 1 \mathrm{Ma}$ (Savelli 1975)) with andesitic lava, dacite domes, and rare hypoabyssal bodies.

Starting from $22 \mathrm{Ma}$ (Beccaluva et al. 1985; Speranza et al. 2002; Gattaceca et al. 2007; Carminati and Doglioni 2012), a highly explosive fissural activity produced abundant pyroclastic dacitic-rhyolitic products, alternated with emissions of basaltic and andesitic lavas. The volcanic emissions occurred in various areas of Sardinia, prevalently along the western graben trending N-S (Figure 1).

The volcanic rocks of Oschiri Basin, which were used for Church of Nostra Signora di Castro, can be attributed to this later volcanic activity. Radiometric ages available for volcanics in the Chilivani-Berchidda Basin area indicate a 23-18 Ma range (Savelli et al. 1979; Oggiano, Pasci, and Funedda 1995; Lecca et al. 1997). The 
pyroclastic materials erupted in the Oschiri Basin from subaerial volcanic centres. They were deposited in a fluvial-lacustrine environment (Vardabasso and Atzeni 1962; Cherchi and Montadert 1982; Sau et al. 2005).

In this Oschiri area, except for the Mesozoic, other geological formations ranging from the Palaeozoic to the Cainozoic also outcrop (Figure 3).

\section{Geographical zonation of the Chilivani-Oschiri area}

Within the western area of the Chilivani-Berchidda Basin, different facies of pyroclastic rocks are observed. On the base of macroscopic petro-volcanological features observed in the field at an early phase of research, this area was divided into two different sectors, an eastern one and a western one in respect to Lake Coghinas and the Rio Mannu river (Figure 3): the Oschiri sector, in which the Church of Nostra Signora di Castro is located (and other churches of Nostra Signora di Otti and San Demetrio), and the ChilivaniTula sector, where many variable pyroclastic products outcrop. Chemical and petrographic analysis proved this field division to be accurate. Moreover, this division closely overlaps the subdivision between the old dioceses of Nostra Signora di Castro (Figure 4(a, b)), further east, and Sant'Antioco of Bisarcio (Figures 3 and $4(e, f)$ ), further west.

Volcanic rocks of the Oschiri and Chilivani/Tula sectors appear in vast outcrops, often made up of several superimposed cooling units with a maximum total thickness of up to several hundred metres. The Oschiri pyroclastic rocks have a clearly lower thickness in respect to the more western Chilivani/Tula ones. Minor outcrops are often made up of one or more cooling units.

Field surveys with extensive sampling in the area of Oschiri and Chilivani, together with the varying geochemical and physical characteristics of the volcanic rocks analysed (Columbu et al. 2014), highlight the presence of pyroclastic rocks with different petrophysical features. According to various authors (Smith 1960; Ragan and Sheridan 1972; Riehle 1973; Peterson 1979; Streck and Grunder 1995; Sparks, Tait, and Yanev 1999; Quane and Russell 2005a; Pioli and and Rosi 2005; Quane and Russell 2005b), these latter depend on several volcanological factors: emplacement modes and temperatures, cooling rates, welding and compaction degree, rates of loss of volatiles during and/or immediately after emplacement, alteration processes; varying presence of ash, pumice (variably flattened and elongated), lithics (from sharp-cornered to rounded), and crystals.

These pyroclastic rocks, being deposited in a fluvial-lacustrine environment, were affected by local processes of halmyrolysis and syn-epigenetic transformations of the deposits (Winchester and
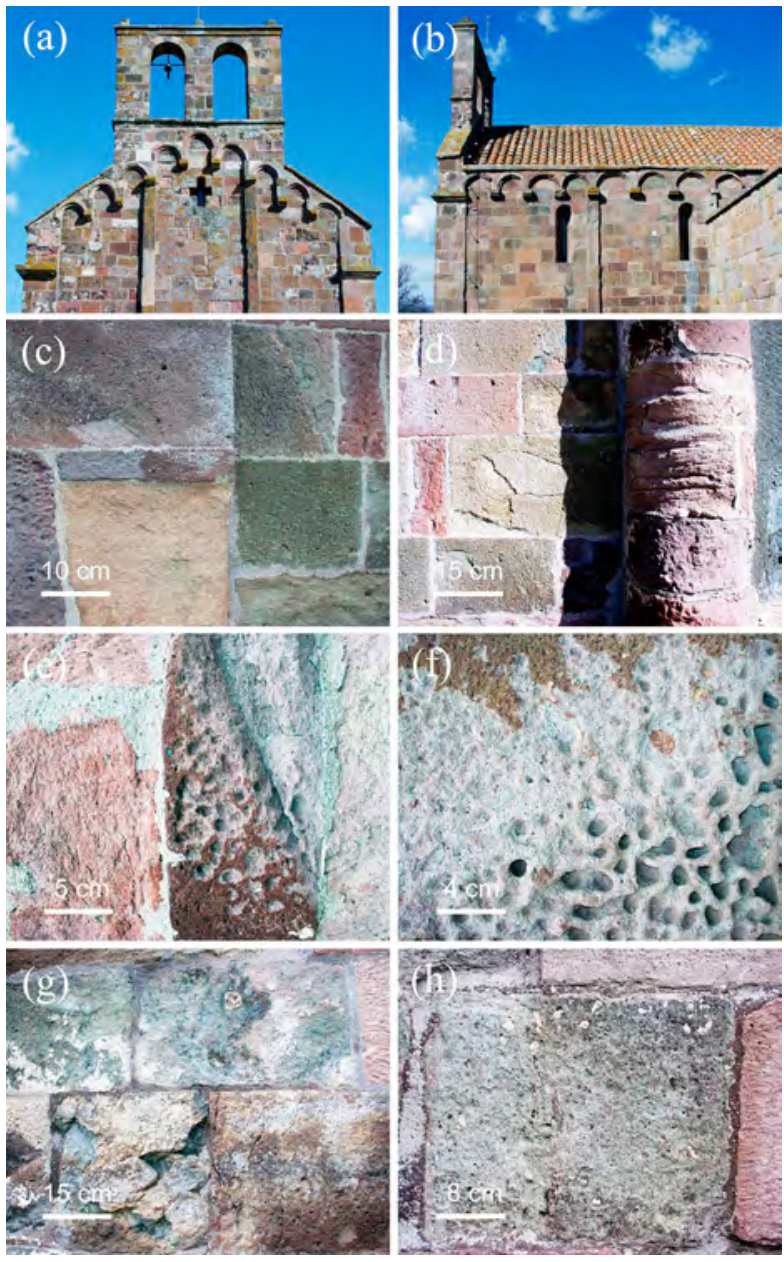

Figure 4. Photographs of ignimbritic ashlars used for the Castro Cathedral: (a) upper part of main west facade; (b) upper part of south facade; (c) main ignimbritic facies used in the Church showing different colours of rock glassy matrix; (d) detail of column base in main facade, showing the differentiated decay of welded and poorly welded volcanics, with exfoliation and flaking processes, also as a function of the orientation of volcanic flow planes of rock (parallel and orthogonal to the facade); (e, f) alveolation decay process in different ignimbritic facies in the main facade, with evident chromatic alteration between the original surface of stone with more saturated colour (upper area of photo) and the actual surface of altered substrate (alveolated zone); (g) fissuring and fracturing processes with loss of material in the apse (east facade), where it is possible to observe the presence of ancient plaster/treatment residues on the masonry, and the cementbased joint mortars (particularly harmful for preservation purposes) used in the last decades in restoration interventions; and (h) greenish poorly-welded ignimbritic facies with glassy matrix decohesion, where it is possible to observe the enucleated phenocrystals of sialic minerals and rare mafic crystals with very small size.

Floyd 1977; Ghiara et al. 1997; Morbidelli et al. 1999; Cerri and Oggiano 2002).

Within the Oschiri sector, according to Columbu (2017), three groups of rocks can be distinguished (see Figure 3): less fractionated pyroclastics of the western zone (LFW), intermediately-fractionated pyroclastics of the central zone (IFC), and more fractionated pyroclastics of the eastern zone (MFE). The zones where 
the LFW and MFE volcanics outcrop are geographically separated by a central zone of IFC volcanics located near the Oschiri station (Figure 3). However, field evidence seems to indicate that IFC volcanics were partially covered by LFW and MFE volcanics.

In the Chilivani/Tula sector, according to Columbu (2017), there are two main pyroclastic facies: welded pyroclastic rocks (WPC), similar to lava-like ignimbrites, where the pumices are small and rarely found, and welded lapilli are always present; unwelded pyroclastic rocks (UPC), cineritic facies of typical fall deposits, with a great compositional heterogeneity due to the variable incidence of lithic fragments, pumice, and phenocrystals (e.g. large biotite).

\section{Results}

\section{The stones of the Nostra Signora di Castro Church}

\section{Macroscopic features}

The volcanic stones used to build the Church of Nostra Signora di Castro (Figure 4) are pumiceous lapilli and ash pyroclastic rocks (ignimbrite) with different colours (from greenish to pinkish to orange-reddish) and with a medium-high welding and consequent good physical-mechanical strength. The juvenile components of the rock are represented by lapilli, ash, and crystals. Lithic clasts consist of fine-grained lava and ignimbrite fragments, with occasionally coarsegrained intrusive and subvolcanic rock fragments. The lapilli and the coarse ash are flame-like (fiammae) and vary from moderately flattened to elongate. On the fresh cut of the rocks, mafic and sialic phases (i.e. pyroxene and more rarely quartz) are visible with size less than a millimetre. Pumices (usually from greenish to ochre colours) are present. Small reddish-brown grains $(<1 \mathrm{~mm})$ are visible, probably belonging to altered mafic minerals.

On the outer surface of ashlar stones, the pumiceous lapilli are less visible with respect to the inside of the rock, due to their erodibility and subsequent physicalmechanical removal. The small reddish-brown phases, also, are less visible on the outer surface. The ignimbrite ashlars show the frequent presence of more or less elongated vacuoles (frequent size: $2-8 \mathrm{~mm}$ ) and pores from irregular to sub-rounded (size: $1-5 \mathrm{~mm}$ ), possibly due to syngenetic degassing processes and secondary alteration (probably at the expense of the pumice), respectively.

\section{Petrographic features}

The petrographic observations are summarised in Table 1, where there are also reported the Thorton and Tuttle differentiation index range (Thornton and Tuttle 1960) and the rock classification on the chemical base according to the main diagrams of Winchester and Floyd (1977), De La Roche et al. (1980), and Le Maitre et al. (2002). The rock classification is based on bulk rock analysis of ignimbrite samples and it is intended for a comparison with the chemical composition of the rocks used as building stones and not for petrogenetic purposes.

All the samples show porphyritic texture, with a porphyritic index generally less than 20\% (frequently between 9 and 15, Table 1), where the phenocrysts are moderately aligned in the direction of the flattened lapilli. The colour index varies from 5 to 7. Textures vary from vitroclastic to eutaxitic to parataxitic to massive vitrophyric (Figure 5).

The mineral paragenesis mainly consists of opaque (i.e. magnetite and Ti-magnetite), plagioclase, and augitic clinopyroxene (often with a border of opaque granules) \pm apatite \pm sanidine \pm quartz \pm biotite. Xenocrystals are also present, mainly represented by plagioclase and pyroxene. The groundmass varies from hypohyaline to hyaline, affected by devitrification. Devitrification structures (i.e. spherulites made up of radially-arranged acicular crystals), according to Lofgren (Le Maitre et al. 2002) are sometimes present. Ti-magnetite and (more rarely) hematite are present in the groundmass. The lithics consist of accidental and/or cognate fragments (with andesitic or andesitic-dacitic composition).

Pumices are generally elongated and flattened. The iso-orientation of lithic clasts and crystals, and both the strong alignment of fiammae and the flattening of pumiceous components indicate a high compaction of the pyroclastic flow, involving the formation of sub-parallel planar discontinuities inside the rock and variable glassy-matrix sintering.

In the most welded pyroclastic samples, the groundmass is compact, with matrix shards nearly adhering among them (where the intergranular porosity has a small pore radius). The vesicles are collapsed and the pumiceous clasts are strongly deformed. On the other hand, in medium welded samples, the sintering is only partial with matrix shards moderately deformed, and a part of the pumices can still be recognised by their still round vesicles.

According to the petrographic-textural features observed in the microscopic analysis (e.g. welding degree, textural/structural parameters, porosity, etc.) the following different pyroclastic facies used were identified:

1) strongly welded pyroclastics (i.e. ignimbrites), with flattened and flame-like pumice (fiammae), flattened filled lithophysae and collapsed vesicles, where intergranular space is strongly reduced, referable to the IV-V welding ranks on the base of petrographic features (according to Quane and Russel classification (Quane and Russell 2005b)); 


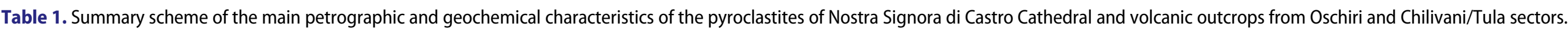

\begin{tabular}{|c|c|c|c|c|c|c|c|c|c|c|c|}
\hline \multirow[b]{3}{*}{$\begin{array}{l}\text { Origin of } \\
\text { samples }\end{array}$} & \multirow{3}{*}{$\begin{array}{l}\text { Lithotype group / } \\
\text { geographic } \\
\text { zonation }\end{array}$} & \multicolumn{4}{|c|}{ Geochemical characteristics } & \multicolumn{6}{|c|}{ Petrographic features by microscopic, SEM, and XRD analysis } \\
\hline & & \multicolumn{3}{|c|}{ Rock classification } & \multirow{2}{*}{$\begin{array}{c}\text { D.I. } \\
\text { (Thornton and } \\
\text { Tuttle 1960) }\end{array}$} & \multirow[b]{2}{*}{ Structure $^{\mathrm{a}}$} & \multirow{2}{*}{$\begin{array}{l}\text { Porphyr. } \\
\text { index (vol } \\
\%)\end{array}$} & \multirow[b]{2}{*}{ Phenocrysts $^{b}$} & \multirow[b]{2}{*}{ Ground mass } & \multirow[b]{2}{*}{ Texture } & \multirow[b]{2}{*}{$\begin{array}{l}\text { Secondary } \\
\text { minerals }^{c}\end{array}$} \\
\hline & & $\begin{array}{l}\text { Le Maitre } \\
\text { et al. } 2002 \\
\end{array}$ & $\begin{array}{l}\text { (De La Roche } \\
\text { et al. 1980) }\end{array}$ & $\begin{array}{l}\text { (Winchester and } \\
\text { Floyd 1977) }\end{array}$ & & & & & & & \\
\hline \multirow[t]{3}{*}{$\begin{array}{l}\text { Ashlars from } \\
\text { Otti church }\end{array}$} & A1-A2-D & $\begin{array}{l}\text { TrDa, Da, } \\
\text { (TrAn) }\end{array}$ & $\begin{array}{l}\text { Rhy, RhyDa, } \\
\text { QzLt, }\end{array}$ & $\begin{array}{l}\text { RhyDa, Da, An, } \\
\text { (TrAn), (Tr) }\end{array}$ & $70-81$ & Porphyric & $10-15$ & $\begin{array}{r}\text { Opq, } \mathrm{Pl}, \pm \mathrm{Opx}, \mathrm{Cpx} \pm \\
\mathrm{Ap}, \pm \mathrm{Bt}, \text { rare Sa, } \pm\end{array}$ & $\begin{array}{l}\text { hyaline, hypohyaline with } \\
\text { crypto-crystalline }\end{array}$ & $\begin{array}{l}\text { from vitroclastic to } \\
\text { eutaxitic to }\end{array}$ & $\begin{array}{l}\text { Fe-Phy, K-Fsp, } \\
\text { Cel, Glt }\end{array}$ \\
\hline & B1-B2 & & (QzTr), (Tr) & & & & & Qz & $\begin{array}{l}\text { assemblage of quartz and } \\
\text { K-feldspar }\end{array}$ & massive vitrophyric & $\begin{array}{l}\text { Fe-Phy, K-Fsp } \pm \\
\text { Cal }\end{array}$ \\
\hline & c & & & & & & & & & & $\begin{array}{l}\text { Fe-Phy, K-Fsp } \pm \\
\text { Cel } \pm \text { Glt }\end{array}$ \\
\hline \multirow[t]{3}{*}{$\begin{array}{l}\text { Outcrops from } \\
\text { Oschiri sector }\end{array}$} & LFW & $\begin{array}{l}\text { TrDa, (Da), } \\
\text { (Rhy) }\end{array}$ & $\begin{array}{l}\text { Rhy, RhyDa, } \\
\text { QzLt }\end{array}$ & $\begin{array}{l}\text { RhyDa, Da, } \\
\text { (TrAn), (An) }\end{array}$ & 70-78 & $\begin{array}{l}\text { Porphyric, } \\
\text { granophyric }\end{array}$ & $9-13$ & $\begin{array}{l}\text { Opq, } \mathrm{Pl}, \pm \mathrm{Opx}, \pm \mathrm{Cpx} \\
\pm \mathrm{Ap}, \pm \mathrm{Bt}, \pm \mathrm{Sa}, \pm \\
\mathrm{Qz}\end{array}$ & hyaline, hypohyaline & $\begin{array}{l}\text { from vitroclastic to } \\
\text { eutaxitic to } \\
\text { massive vitrophyric }\end{array}$ & $\begin{array}{l}\text { Fe-Phy, K-Fsp, } \\
\text { Cel, Glt }\end{array}$ \\
\hline & IFC & & $\begin{array}{l}\text { Rhy, RhyDa, } \\
\text { (QzLt) }\end{array}$ & & $76-79$ & & $10-14$ & $\begin{array}{l}\text { Opq, } \mathrm{Pl}, \pm \mathrm{Opx}, \pm \mathrm{Cpx} \\
\pm \mathrm{Ap}, \pm \mathrm{Bt}, \pm \mathrm{Sa}, \pm \\
\mathrm{Qz}\end{array}$ & & & \\
\hline & MFE & & Rhy & & 77-82 & & $11-15$ & $\begin{array}{l}\text { Opq, } \mathrm{Pl}, \pm \mathrm{Opx}, \pm \mathrm{Cpx} \\
\pm \mathrm{Ap}, \pm \mathrm{Bt}, \text { rare } \mathrm{Sa} \\
\pm \mathrm{Qz}\end{array}$ & & & \\
\hline \multirow[t]{2}{*}{$\begin{array}{l}\text { Outcrops from } \\
\text { Chilivani/Tula } \\
\text { sector }\end{array}$} & WPC & $\begin{array}{l}\text { Rhy, Da, } \\
\text { TrDa }\end{array}$ & QzLt & $\begin{array}{l}\text { RhyDa, Da, } \\
\text { (TrAn) }\end{array}$ & $82-88$ & Porphyric & 5-15 & $\begin{array}{l}\text { Opq, PI, } \pm \text { Opx, rare } \\
\text { Cpx, KFsp, Qz rare } \\
\text { Hbl }\end{array}$ & hyaline, hypohyaline & $\begin{array}{l}\text { from eutaxitic to } \\
\text { vitrophyric }\end{array}$ & $\begin{array}{l}\text { Mor, silica phases } \\
\text { (e.g. Opl-CT), } \\
\text { Hm, Chl }\end{array}$ \\
\hline & UPC & & $\begin{array}{l}\text { Rhy, RhyDa, } \\
\text { (QzLt) }\end{array}$ & & $71-89$ & Porphyric & $7-18$ & $\begin{array}{l}\text { Opq, Pl, } \pm \text { Opx }, C p x, \pm \\
\text { Bt, KFsp, Qz }\end{array}$ & hyaline, hypohyaline & & \\
\hline
\end{tabular}

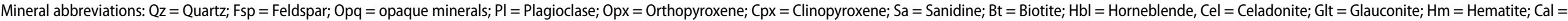

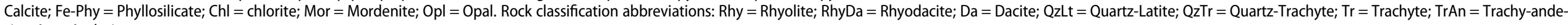
site; $A n=$ Andesite.

according to increasing presence.

${ }^{\mathrm{b}}$ According to their increasing abundance.

'According to their increasing abundance. 


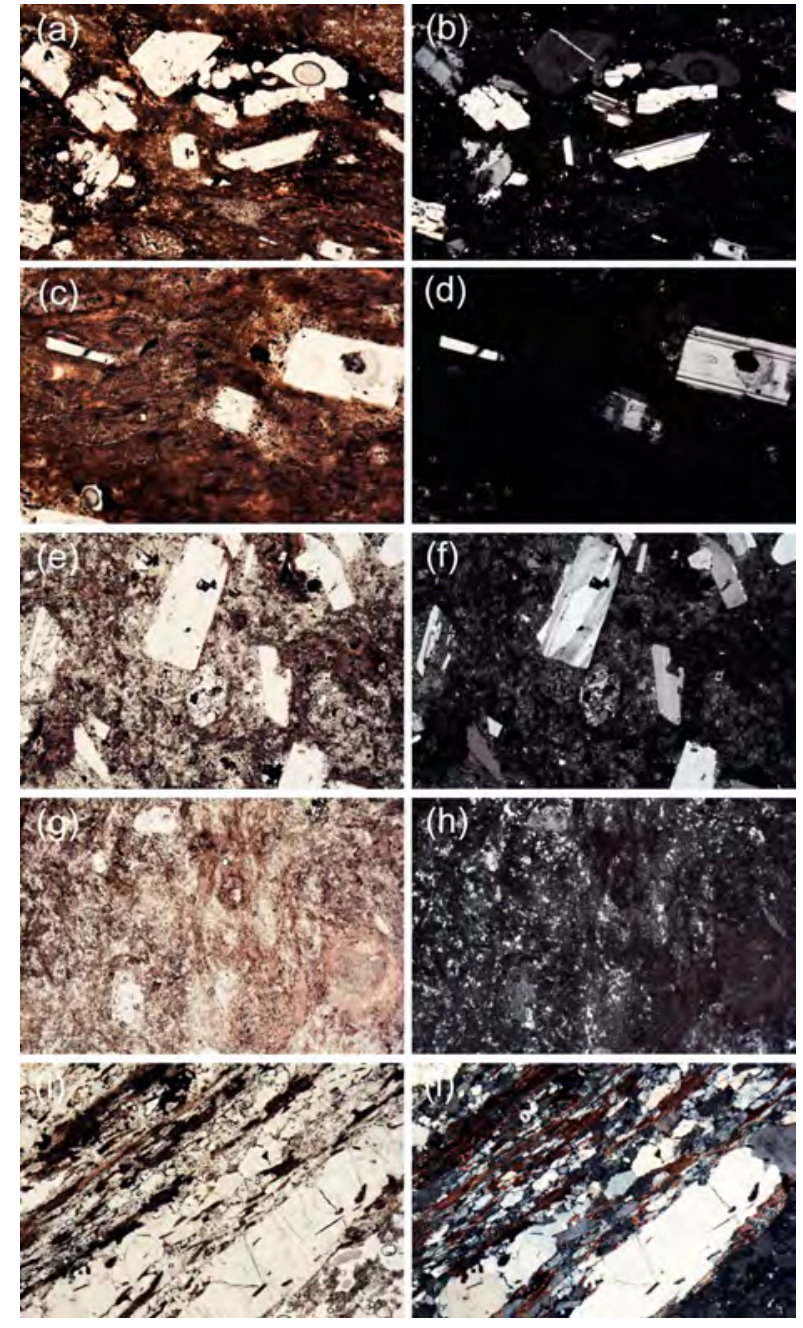

Figure 5. Microphotographs of thin sections (crossed nicols on the right, parallel nicols on the left) of ignimbrite rock samples from IFC (a, b, c, d), LFW (e, f), and MFE ( $g, h)$, showing examples of the pyroclastic texture. (i, I): a lithic clast in the MFE ignimbrite rock. Scale: the long side of the photos is $5.1 \mathrm{~mm}$ except for C, D which are $1.35 \mathrm{~mm}$.

2) welded pyroclastics, with rare (or absent) finegrained phyllosilicates inside the porosity, referable to the IV welding rank based on petrographic characteristics; and

3) from slightly welded to unwelded pyroclastics, with the presence of open lithophysae and fine-grained phyllosilicates lining porosity, referable to the III-IV welding ranks based on petrographic features.

\section{Geochemical characteristics and rock classification}

Tables 2-4 report the chemical analyses of the samples from the Church of Nostra Signora di Castro, where the alkali sum, the differentiation index (D.I. = normative $\mathrm{Q}$ $+\mathrm{Ab}+\mathrm{Or}+\mathrm{Ne}+\mathrm{Kp}+\mathrm{Lc}$; Thornton and Tuttle (1960) and the alumina saturation index (A.S.l., defined as the molecular ratio $\left[\mathrm{Al}_{2} \mathrm{O}_{3}\right] /\left([\mathrm{CaO}]-1.67 \quad\left[\mathrm{P}_{2} \mathrm{O}_{5}\right]+\right.$ $\left.\left[\mathrm{Na}_{2} \mathrm{O}\right]+\left[\mathrm{K}_{2} \mathrm{O}\right]\right)$ are reported.

According to the Total Alkali Silica (TAS) diagram of Le Maitre et al. (2002) (Figure 7(a)), the samples of the
Church of Nostra Signora di Castro are classified as trachydacite and trachyte, and subordinately as trachyandesite with a sample into the dacite field. The samples overlap the discriminant line of Irvine and Baragar (Winchester and Floyd 1977) distinguishing the alkaline from the subalkaline series (Figure 7(a)).

For a comparison, the $R_{1}$ vs $R_{2}$ diagram of De La Roche et al. (1980) was also used, because it is generally more in accordance with the petrographic classification on a microscopic basis and because it includes more chemical elements $\left(\mathrm{R}_{1}=4 \mathrm{Si}-11(\mathrm{Na}+\mathrm{K})-2(\mathrm{Fe}+\mathrm{Ti}) ; \mathrm{R}_{2}=\right.$ $6 \mathrm{Ca}+2 \mathrm{Mg}+\mathrm{Al}$ ) with respect to the TAS diagram. According to the $R_{1}-R_{2}$ diagram (modified; Figure 6) the ignimbritic samples of the Church of Nostra Signora di Castro are mainly classified as quartz-latite, rhyodacite, dacite and rhyolite and, subordinately, as quartz-trachyte, trachyte, and trachy-andesite.

Moreover, considering the variable alteration degree of the rocks, the classification binary diagrams of Winchester and Floyd (1977), using some incompatible elements $(\mathrm{Nb}, \mathrm{Y}, \mathrm{Zr})$, immobile during the alteration, were also used. According to these diagrams $(\mathrm{Nb} / \mathrm{Y}$ vs $\mathrm{SiO}_{2}$ wt\%, Figure $8(\mathrm{a}) ; \mathrm{Zr} / \mathrm{TiO}_{2} \mathrm{ppm}$ vs $\mathrm{SiO}_{2} \mathrm{wt} \%$, Figure $8(\mathrm{c})$; and $\mathrm{Nb} / \mathrm{Y}$ ppm vs $\mathrm{Zr} / \mathrm{TiO}_{2} \mathrm{ppm}$, Figure 8 (e)), the samples of the Church of Nostra Signora di Castro fall mainly in the rhyodacite, dacite, and andesite fields (Figure $8(a, c, e)$ ) and, subordinately, in the trachyandesite field (Figure 8c), highlighting their geochemical features closer to those shown in the $R_{1}$ vs $R_{2}$ diagram (Figure 6).

For the reasons mentioned above, the diagram of De La Roche et al. (1980) was used as the main classification scheme of the analysed volcanic rocks.

\section{Field pyroclastic rocks}

\section{Petrographic features}

The juvenile clasts of the pyroclastites of the different subzones of Oschiri sector show relatively similar microscopic characteristics as regards their paragenesis, porphyritic index (P.I. 9-15), and colour index (C.I. 2-6), Table 1.

The phenocryst assemblage consists of plagioclase (with labradorite to andesine compositions), \pm clinopyroxene (with augitic composition), \pm sanidine \pm quartz \pm biotite, Fe-Ti oxides \pm apatite as accessories. Xenocrystals with varying composition, principally plagioclase and pyroxene, are also present.

The groundmass is from hyaline to hypohyaline. Textures vary from vitroclastic to eutaxitic, to parataxitic, to massive vitrophyric. Locally, there are granophyric intergrowths of quartz and feldspars, indicating low cooling speeds.

Two generations of plagioclase phenocrysts can be recognised. The plagioclase crystals of the first generation (from subhedral to anhedral) show evident disequilibrium with the liquid, and are clearly zoned, 
Table 2. Chemical analysis of selected volcanics from the Church of Nostra Signora di Castro Cathedral.

\begin{tabular}{|c|c|c|c|c|c|c|c|c|c|c|c|c|c|c|c|c|c|c|c|c|c|c|c|c|c|}
\hline $\begin{array}{l}\text { Sample } \\
\text { Subsig. }\end{array}$ & $\begin{array}{c}1 \\
\operatorname{CO} 15 \\
A^{-}\end{array}$ & $\begin{array}{c}2 \\
\mathrm{CO} 1 \mathrm{~A} \\
\mathrm{~A}+\end{array}$ & $\begin{array}{c}3 \\
\mathrm{CO}_{2} \mathrm{SS} \\
\mathrm{A}^{-}\end{array}$ & $\begin{array}{c}4 \\
\text { CO82A } \\
\mathrm{A}+\end{array}$ & $\begin{array}{c}5 \\
\mathrm{CO} 84 \mathrm{~S} \\
\mathrm{~A}^{-} \\
\end{array}$ & $\begin{array}{c}6 \\
\text { CO84A } \\
\mathrm{A}+ \\
\end{array}$ & $\begin{array}{c}7 \\
\text { CO85S } \\
A^{-} \\
\end{array}$ & $\begin{array}{c}8 \\
\text { CO85A } \\
\mathrm{A}+ \\
\end{array}$ & $\begin{array}{c}9 \\
\text { CO865 } \\
A^{-}\end{array}$ & $\begin{array}{c}10 \\
\mathrm{CO} 86 \mathrm{~A} \\
\mathrm{~A}+\end{array}$ & $\begin{array}{c}11 \\
\text { CO88A } \\
\mathrm{A}+\end{array}$ & $\begin{array}{c}12 \\
\text { CO90S } \\
\mathrm{A}^{-}\end{array}$ & $\begin{array}{c}13 \\
\mathrm{CO} 90 \mathrm{~A} 1 \\
\mathrm{~A}+\end{array}$ & $\begin{array}{c}14 \\
\mathrm{CO} 90 \mathrm{~A} 2 \\
\mathrm{~A}+\end{array}$ & $\begin{array}{c}15 \\
\text { CO95S } \\
A^{-}\end{array}$ & $\begin{array}{c}16 \\
\mathrm{CO} \\
\mathrm{A}+ \\
\end{array}$ & $\begin{array}{c}17 \\
\text { CO96S } \\
A^{-}\end{array}$ & $\begin{array}{c}18 \\
\text { CO96A } \\
\mathrm{A}+\end{array}$ & $\begin{array}{c}19 \\
\text { CO975 } \\
A^{-}\end{array}$ & $\begin{array}{c}20 \\
\mathrm{CO} 97 \mathrm{~A} 1 \\
\mathrm{~A}+\end{array}$ & $\begin{array}{c}21 \\
\text { CO97A2 } \\
\mathrm{A}+\end{array}$ & $\begin{array}{c}22 \\
\mathrm{CO} 115 \mathrm{~S} \\
\mathrm{~A}^{-}\end{array}$ & $\begin{array}{c}23 \\
\mathrm{CO} 115 \mathrm{~A} 1 \\
\mathrm{~A}+\end{array}$ & $\begin{array}{c}24 \\
\mathrm{CO} 115 \mathrm{~A} 2 \\
\mathrm{~A}+\end{array}$ & $\begin{array}{c}25 \\
\mathrm{CO} 120 \mathrm{~A} \\
\mathrm{~A}+\end{array}$ \\
\hline Class. R1-R2 & qzLt & qzLt & qzLt & RyDc & $\operatorname{Tr}$ & qzLt & RyDc & Dc & qzLt & qzLt & qzLt & $q z \operatorname{Tr}$ & Dc & qzTr & $q z \operatorname{Tr}$ & $\mathrm{Lt}$ & qzLt & qzLt & qzLt & Dc & qzLt & qzLt & Dc & RyDc & qzLt \\
\hline $\mathrm{SiO}_{2}$ & 60.93 & 60.75 & 65.13 & 64.82 & 61.80 & 61.24 & 64.51 & 61.97 & 62.76 & 60.64 & 62.77 & 63.30 & 63.29 & 62.57 & 60.39 & 57.39 & 61.67 & 61.99 & 64.77 & 63.01 & 63.96 & 61.94 & 62.99 & 64.51 & 61.13 \\
\hline $\mathrm{TiO}_{2}$ & 0.79 & 0.79 & 0.64 & 0.66 & 0.64 & 0.67 & 0.66 & 0.73 & 0.66 & 0.64 & 0.66 & 0.71 & 0.68 & 0.65 & 0.71 & 0.68 & 0.84 & 0.77 & 0.70 & 0.70 & 0.71 & 0.65 & 0.67 & 0.68 & 0.81 \\
\hline $\mathrm{Al}_{2} \mathrm{O}_{3}$ & 16.10 & 16.43 & 14.06 & 13.88 & 13.70 & 13.70 & 14.01 & 13.63 & 14.01 & 13.53 & 13.81 & 14.47 & 14.47 & 14.10 & 14.68 & 13.80 & 15.92 & 15.55 & 15.23 & 13.66 & 14.59 & 12.43 & 13.41 & 13.21 & 15.93 \\
\hline $\mathrm{Fe}_{2} \mathrm{O}_{3}$ & 4.84 & 5.21 & 4.22 & 4.27 & 5.05 & 4.69 & 5.93 & 5.27 & 5.21 & 5.01 & 5.02 & 5.16 & 5.08 & 4.83 & 5.66 & 5.09 & 5.84 & 5.70 & 4.05 & 3.89 & 4.15 & 6.47 & 5.28 & 5.95 & 5.78 \\
\hline $\mathrm{FeO}$ & 0.55 & 0.21 & 0.56 & 0.46 & 0.21 & 0.10 & 0.20 & 0.47 & 0.24 & 0.18 & 0.20 & 0.10 & 0.20 & 0.24 & 0.12 & 0.11 & 0.44 & 0.22 & 0.32 & 1.51 & 0.49 & 0.11 & 0.12 & 0.41 & 8.00 \\
\hline $\mathrm{MnO}$ & 0.10 & 0.10 & 7.00 & 6.00 & 0.13 & 0.14 & 8.00 & 0.10 & 0.10 & 8.00 & 0.14 & 0.11 & 0.15 & 0.12 & 0.10 & 0.14 & 0.13 & 0.12 & 9.00 & 9.00 & 0.10 & 0.10 & 8.00 & 0.13 & 0.12 \\
\hline $\mathrm{MgO}$ & 1.72 & 1.45 & 1.20 & 1.42 & 1.65 & 1.53 & 1.46 & 1.85 & 1.02 & 0.87 & 1.47 & 1.18 & 1.47 & 1.53 & 0.90 & 0.81 & 1.10 & 1.07 & 1.52 & 2.26 & 1.72 & 1.84 & 1.56 & 1.81 & 0.96 \\
\hline $\mathrm{CaO}$ & 3.57 & 3.56 & 2.97 & 2.87 & 2.84 & 3.98 & 3.30 & 4.59 & 3.71 & 5.01 & 3.69 & 2.65 & 3.45 & 2.81 & 3.94 & 6.23 & 3.55 & 3.63 & 3.07 & 3.49 & 3.26 & 4.28 & 3.83 & 3.11 & 4.03 \\
\hline $\mathrm{Na}_{2} \mathrm{O}$ & 3.87 & 3.80 & 3.79 & 3.69 & 4.00 & 3.04 & 3.52 & 3.65 & 3.94 & 3.91 & 3.92 & 3.64 & 1.69 & 4.07 & 4.05 & 3.49 & 3.82 & 3.65 & 4.10 & 3.49 & 4.20 & 3.52 & 3.53 & 3.11 & 4.17 \\
\hline $\mathrm{K}_{2} \mathrm{O}$ & 5.17 & 5.37 & 4.45 & 4.15 & 6.92 & 6.85 & 3.95 & 3.79 & 4.81 & 4.65 & 5.12 & 6.49 & 6.60 & 6.16 & 5.55 & 4.95 & 5.60 & 5.65 & 4.36 & 4.55 & 4.20 & 4.73 & 4.34 & 4.69 & 4.78 \\
\hline P2O5 & 0.47 & 0.28 & 0.42 & 0.34 & 0.34 & 0.94 & 0.30 & 0.99 & 0.45 & 0.37 & & 0.29 & 0.74 & 0.25 & 0.74 & 1.78 & 0.30 & 0.35 & 0.23 & 0.39 & 0.27 & 0.24 & 0.33 & 0.31 & 0.60 \\
\hline L.O.I. & 1.88 & 2.03 & 2.49 & 3.37 & 2.73 & 3.13 & 2.00 & 2.96 & 3.11 & 5.09 & 2.81 & 1.91 & 2.19 & 2.68 & 3.15 & 5.53 & 0.78 & 1.29 & 1.56 & 2.97 & 2.34 & 3.70 & 3.87 & 2.08 & 1.61 \\
\hline Total & 99.99 & 99.98 & 100.00 & 99.99 & 1001.00 & 1001.00 & 99.92 & 100.00 & 1002.00 & 99.98 & 100.00 & 1001.00 & 1001.00 & 1001.00 & 99.99 & 100.00 & 99.99 & 99.99 & 100.00 & 1001.00 & 99.99 & 1001.00 & 1001.00 & 100.00 & 100.00 \\
\hline S.I. & 15.99 & 13.65 & 12.71 & 15.33 & & 13.40 & 16.35 & 19.91 & 10.44 & 9.23 & 13.99 & 10.43 & 15.06 & 13.01 & 8.57 & 8.76 & 10.46 & 10.32 & 15.23 & 21.94 & 17.00 & 18.24 & 16.54 & 18.83 & 9.69 \\
\hline Mg Val. & 0.38 & 0.35 & 0.33 & 0.37 & 0.38 & 0.39 & 0.32 & 0.39 & 0.27 & 0.25 & 0.36 & 0.31 & 0.35 & 0.37 & 0.24 & 0.24 & 0.26 & 0.26 & 0.41 & 0.45 & 0.42 & 0.36 & 0.36 & 0.36 & 0.24 \\
\hline A.l. & 0.74 & 0.73 & 0.79 & 0.76 & 1.0 & 0.91 & 0.72 & 0.74 & 0.83 & 0.85 & 0.8 & 90 & 0.69 & 0.95 & 0.86 & 0.80 & 0.78 & 78 & 0.75 & 0.78 & 0.7 & & & 0.77 & 0.76 \\
\hline Q & 7.61 & 7.09 & 17.34 & 18.30 & 4.36 & 8.79 & 17.93 & 14.77 & 12.24 & 9.94 & 10.85 & 9.43 & 17.82 & 7.19 & 6.76 & 8.36 & 7.51 & 8.93 & 14.52 & 13.99 & 13.48 & 11.81 & 15.27 & 17.55 & 8.27 \\
\hline C & 0.00 & 0.00 & 0.00 & 0.00 & 0.00 & & 0.00 & 0.00 & 0.00 & 0.00 & 0.00 & 0.00 & 5.00 & 0.00 & 0.00 & 0.00 & 0.00 & & & 0.00 & & & & & 0.00 \\
\hline Or & 30.55 & 31.73 & 26.30 & 24.52 & 40.89 & 40.48 & 23.34 & 22.40 & 28.42 & 27.48 & 30.25 & 38.35 & 39.00 & 36.40 & 32.80 & 29.25 & 33.09 & 33.39 & 25.7 & 26.89 & 24.8 & 27.95 & 25.65 & 27.71 & 28.25 \\
\hline $\mathrm{Ab}$ & 32.74 & 32.15 & 32.07 & 31.22 & 31.94 & 25.72 & 29.78 & 30.88 & 33.34 & 33.08 & 33.17 & 30.80 & 14.30 & 34.44 & 34.27 & 29.53 & 32.32 & 30.88 & 34.6 & 29.53 & 35. & 29.78 & 29.87 & 26.31 & 35.28 \\
\hline An & 29 & 11.91 & & & & & 10.76 & 9.61 & & 5.63 & & & & 2.01 & & 7.37 & 9.75 & & & 8.17 & & & & & 10.63 \\
\hline$A C$ & 0.00 & 0.00 & & & & & 0.0 & 0. & & 0.00 & & & & 0.00 & 0. & 0.00 & 0.00 & Do & & 0.00 & & 00 & 0.00 & 0.00 & 0.00 \\
\hline $\mathrm{Di}$ & 1.23 & 1. & & 1. & 4.08 & 3.69 & 1. & 2.44 & 2.40 & 4.13 & 3. & & 0.00 & 3.62 & & 2.77 & 1.50 & & & 2.72 & & & 3.08 & 1.73 & 1.33 \\
\hline $\mathrm{Ed}$ & 1.58 & 1.99 & 1.9 & 1. & 5.91 & 4.78 & 1.98 & 3.16 & 5.39 & 10.25 & 5. & 3. & 0.0 & 5.0 & 5.76 & 7.44 & 3.54 & & 1.5 & 2.77 & 2.5 & 7.92 & 4.42 & 2.62 & 3.33 \\
\hline $\mathrm{SI}$ & 2.81 & 3.30 & 3.20 & 2. & 9.99 & 8.47 & 3.09 & 5.61 & 7.79 & 14.38 & 9.09 & 6. & 0.00 & 8.65 & 7.91 & 10.21 & 5.04 & 5.43 & 2.88 & 5.49 & 4.8 & 13.09 & 7.50 & 4.36 & 4.66 \\
\hline En & & & & & 2.22 & & & & & 0.25 & & & & & & & & & & & & & & & 1.77 \\
\hline Fs & 5.44 & 5.21 & 4.5 & 4.75 & 3.69 & 3.1 & 6.36 & 5. & 3. & 0.71 & & & & 3. & 3. & 2.26 & 5.56 & & & 5.1 & & & 4.0 & 6.42 & 5.08 \\
\hline Hy & 9.16 & & & 7.8 & & & 9.4 & & & 0.96 & & & 101 & & & & 7.61 & & & & & & & & 6.86 \\
\hline $\mathrm{Mt}$ & 0.94 & 0.9 & & 0.8 & 7. & & 1. & & & 0. & & & & & & 0.90 & 1.09 & & & & & & & & 1.01 \\
\hline$\|$ & 1.50 & 1. & & & & & 1.2 & & & 1.2 & & & & & & 1.29 & 1.60 & & & 1.3 & & & & 1.2 & 1.54 \\
\hline Ap & 1.09 & & & & & & 0. & & 1.04 & 0.86 & & & & 0.58 & & 4.12 & 0.69 & & & 0.90 & & & & & 1.39 \\
\hline D.I. & 70.91 & 70.97 & 75.70 & 74.05 & 77.19 & 74.99 & 71.06 & 68.05 & 74.00 & 70.50 & 74.27 & 78.58 & 71.12 & 78.03 & 73.82 & 67.14 & 72.92 & 73.20 & 74.9 & 70.40 & 73. & 69.54 & 70.78 & 71.57 & 71.80 \\
\hline SAL & & 82.89 & & & & & & & & 76.13 & & & & 804.00 & & 74.51 & 82.67 & & 8 & 78.57 & 9 & 9 & & & 82.43 \\
\hline FEM & 15.49 & 14.61 & 13. & 13.15 & 19.65 & 17.98 & 15.58 & 18.92 & 12 & 18.32 & 17.51 & 15.09 & 13. & 16.87 & 17.03 & 19.52 & 16.03 & 15.64 & 12.84 & 18.15 & 14. & 22.05 & 16.97 & 17.59 & 15.46 \\
\hline V & 6 & 55.1 & 37. & & & 46.6 & 62.5 & & 47 & 44.2 & 50.8 & 49 & 49 & 47.5 & 48.4 & 45.9 & 67.1 & 54.4 & 41.9 & 48.9 & 41. & 59.1 & 59.5 & 60.5 & 48.5 \\
\hline $\mathrm{Ni}$ & 5.6 & 8.3 & 5. & 5. & 7. & 5. & 5.1 & 5. & 5 & 3.2 & 5. & 4.9 & 7. & 6. & 6.2 & 5.7 & 5.6 & 6 & 6 & 4.5 & 4 & 6. & 4.1 & 6.8 & 4.6 \\
\hline $\mathrm{Zn}$ & 105.0 & 99.5 & 97.0 & 101.0 & 87.0 & 91.7 & 81.5 & 103.0 & 85 & 77.7 & & 218.0 & 143.0 & 91.9 & 85.0 & 89.1 & 85.2 & 74.8 & 86.1 & 94.7 & 96.0 & 74.3 & 78.6 & 91.2 & 71.0 \\
\hline $\mathrm{Rb}$ & & 126 & 188 & & & & 139 & & & 150 & 161 & & & 216 & 141 & & 144 & & & & & & 190 & & 122 \\
\hline $\mathrm{Sr}$ & & 2 & 21 & & & 17 & 23 & & & 22 & & & & 17 & 2 & & 2 & & & & & & 2 & & 254 \\
\hline $\mathrm{Ba}$ & & 7 & 552 & 5 & & & 5 & 5 & & & 5 & 101 & & 5 & 5 & & & & & & & & & & 564 \\
\hline $\mathrm{Zr}$ & 213 & 226 & 195 & 194 & 193 & 182 & 190 & 176 & 186 & 181 & 180 & 187 & & 192 & 190 & 176 & 181 & 187 & 220 & 201 & 212 & 174 & 179 & 178 & 183 \\
\hline $\mathrm{Pb}$ & 20.0 & 35.6 & n.d. & 33.4 & 17.3 & 12.5 & 22.2 & 13.5 & 36.7 & 23.0 & 14.9 & 37.1 & 38.6 & 18.4 & n.d. & 19.6 & 15.1 & 28.8 & 27.3 & 21.4 & n.d. & 21.3 & n.d. & 17.0 & n.d. \\
\hline $\mathrm{Nb}$ & 12 & 9.5 & 9.1 & & 9.5 & 8.6 & 9.5 & & 6.8 & & 9.2 & & & & 8.4 & 7.8 & & 10.5 & & 9.0 & 12.0 & 9. & 13.8 & 11.1 & 10.8 \\
\hline $\mathrm{Y}$ & 37.4 & 50.2 & 39.9 & 49.8 & 38.2 & 45.0 & 35.8 & 39.3 & 36.9 & 29.0 & 34.0 & 37.2 & 42.2 & 39. & 33.4 & 26.0 & 33.6 & 31.8 & 41. & 45.0 & 54. & 42.2 & 35.9 & 47.8 & 36.3 \\
\hline La & 35 & 38.2 & 33 & & 26 & & & & & & & & 3 & 20 & & 23. & 32. & 23 & & 40. & & & 29.4 & 25.0 & 10.5 \\
\hline $\mathrm{Ce}$ & 54.8 & 76.0 & 53.4 & 69.8 & 49.3 & 56.2 & 49.3 & 69.4 & 55.8 & 45.7 & 46.3 & 48.1 & 53.4 & 56.3 & 48.4 & 58.9 & 32.9 & 49.4 & 59.7 & 62.0 & 58.0 & 45.9 & 58.2 & 59.1 & 50.0 \\
\hline
\end{tabular}

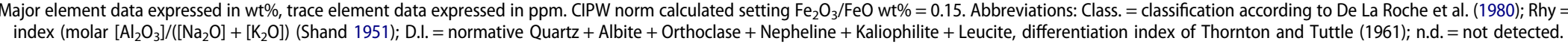


Table 3. Chemical analysis of selected volcanics from the Church of Nostra Signora di Castro Cathedral.

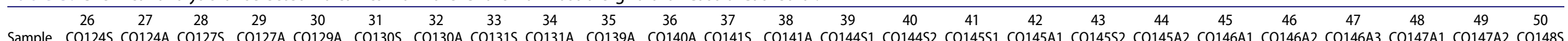

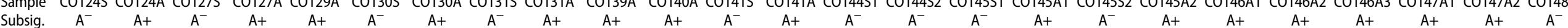

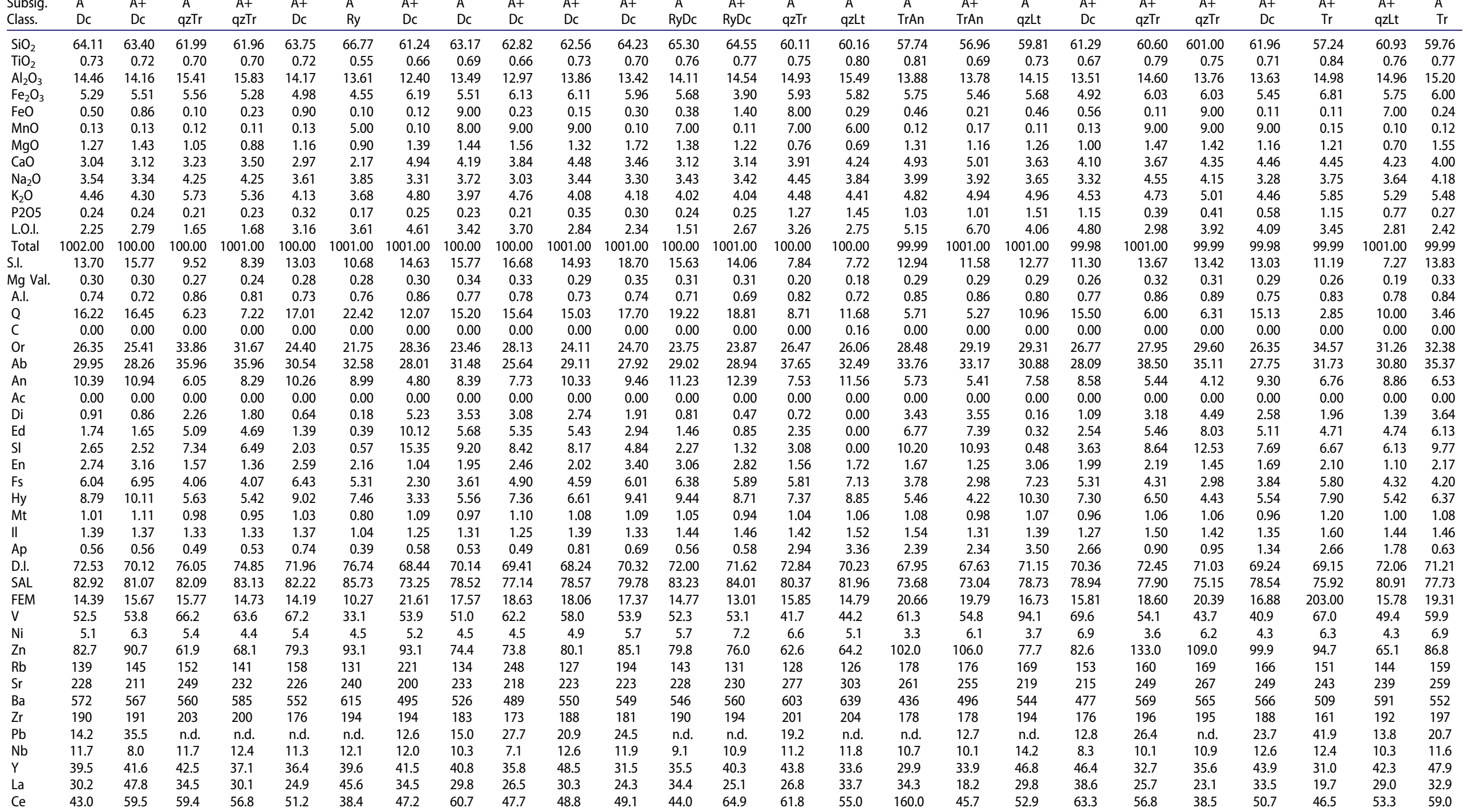

Major element data expressed in wt\%, trace element data expressed in ppm. CIPW norm calculated setting $\mathrm{Fe}_{2} \mathrm{O}_{3} / \mathrm{FeO} \mathrm{wt} \%=0.15$. Abbreviations as Table 2 . 
Table 4. Chemical analysis of selected volcanics from the Church of Nostra Signora di Castro Cathedral.

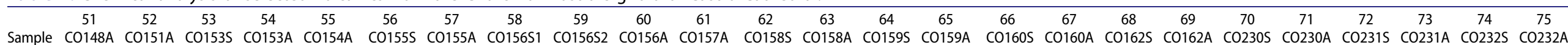

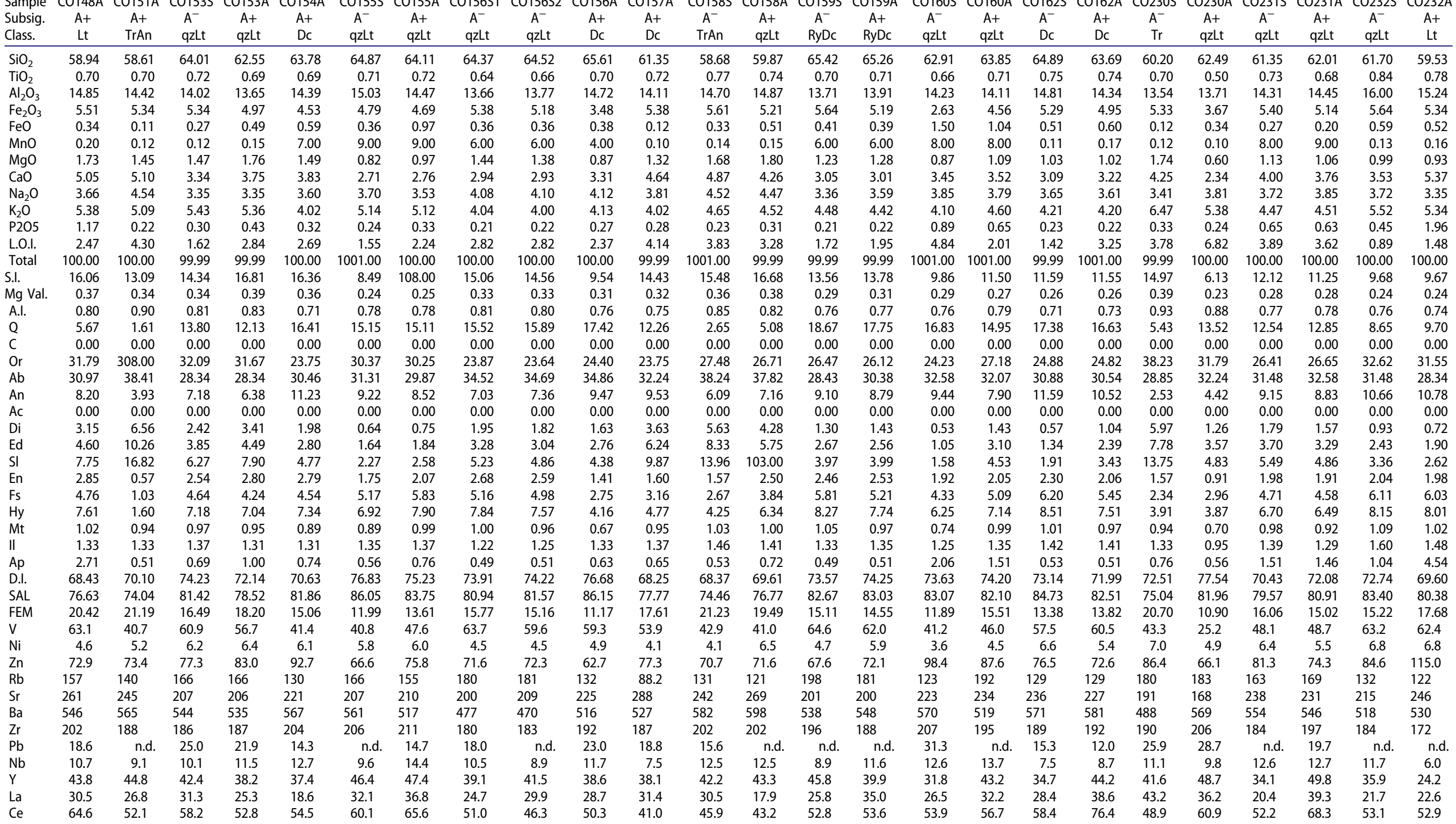

Major element data expressed in wt\%, trace element data expressed in ppm. CIPW norm calculated setting $\mathrm{Fe}_{2} \mathrm{O}_{3} / \mathrm{FeO}=0.15$. Abbreviations as in Table 2 . 

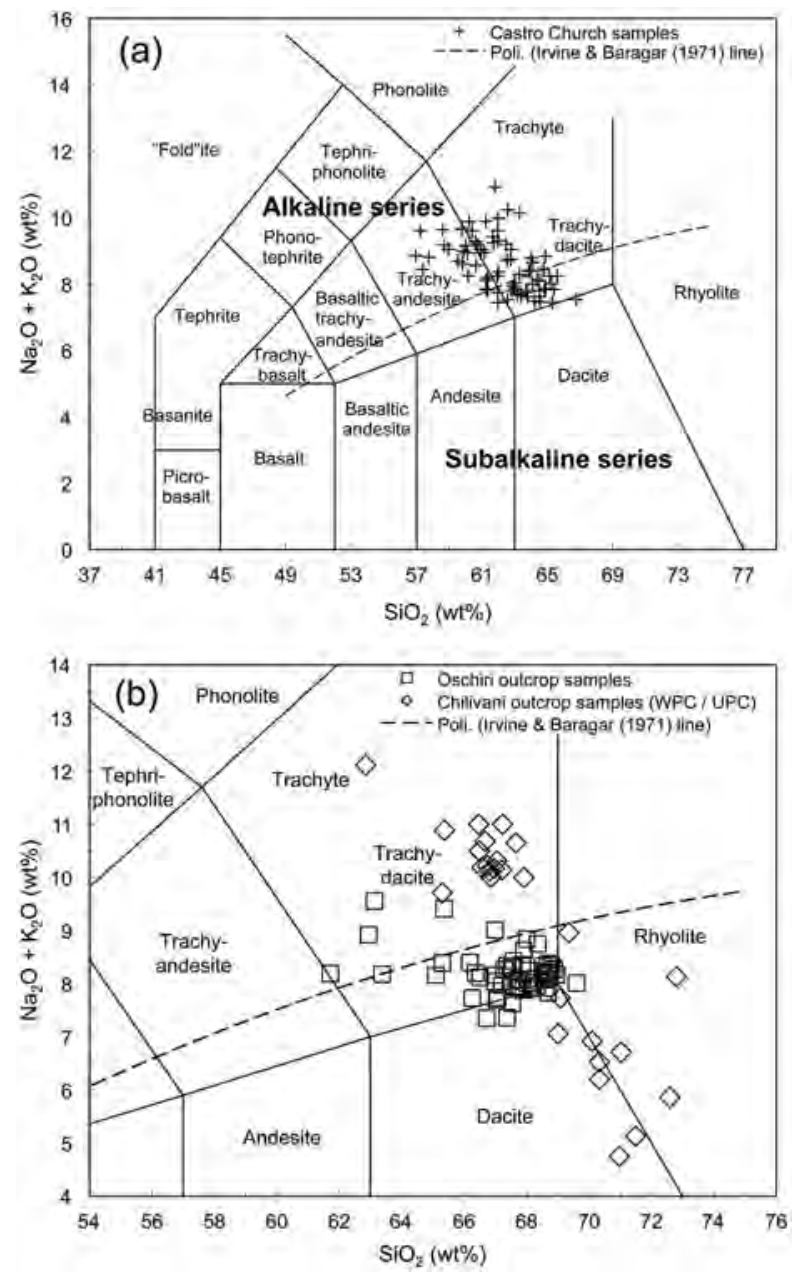

Figure 6. Total Alkali Silica (T.A.S.) classification diagram of Le Maitre et al. (2002, modified): $\mathrm{Na}_{2} \mathrm{O}+\mathrm{K}_{2} \mathrm{O}$ versus $\mathrm{SiO}_{2}$ (wt\%). (a) samples from the Castro Church; (b) samples from field. Graphic symbols: crosses = monument samples from this work; squares = outcrop samples from Oschiri sector; rhombus = outcrop samples from Chilivani/Tula sector (WPC, UPC pyroclastics). occasionally with oscillatory zoning, showing resorption and include ( $\mathrm{Ti}-)$ magnetite microphenocrystals $(<1 \mathrm{~mm})$ and, rarely, clinopyroxene. They are often broken, with sharp edges. In the more evolved products, they are sometimes surrounded by neoformation rims in equilibrium with the liquid. In some cases, the plagioclase of the second generation appears weakly zoned with from euhedral to subhedral habitus, without any signs of disequilibrium. They sometimes include opaque oxides of dimensions $<200 \mu \mathrm{m}$. As regards the size of plagioclases, all analysed samples show a bimodal size distribution with larger dimensions $(<4 \mathrm{~mm})$ of the first generation of plagioclase and smaller dimensions $(<2 \mathrm{~mm})$ of the later ones.

Ti-magnetite occurs as microlites $(\leq 0.2 \mathrm{~mm})$, present in the groundmass and as microphenocrystals $(<1 \mathrm{~mm})$, included in the various phenocrystals or scattered in the groundmass.

Besides these overall similar characteristics, some differences between the volcanics of the sub-zones of Oschiri sector are present.

The less fractionated western pyroclastites (LFW) show on average a porphyritic index around 11 (Table 1; Figure 5(e, f)) and a colour index around 6. The paragenesis consists, in addition to plagioclases, of rare augitic clinopyroxene (often with a border of opaque granules), microphenocrystals of (Ti-) magnetite, \pm apatite \pm sanidine \pm quartz \pm biotite. Abundant microgranules of Ti-magnetite \pm hematite are present in the groundmass. There are lithic, accidental and/or cognate fragments (generally with rounded edges) with an andesitic or andesitic-dacitic composition that contain plagioclase and pyroxene microlites. Pumices are rare (than in MFE samples), generally

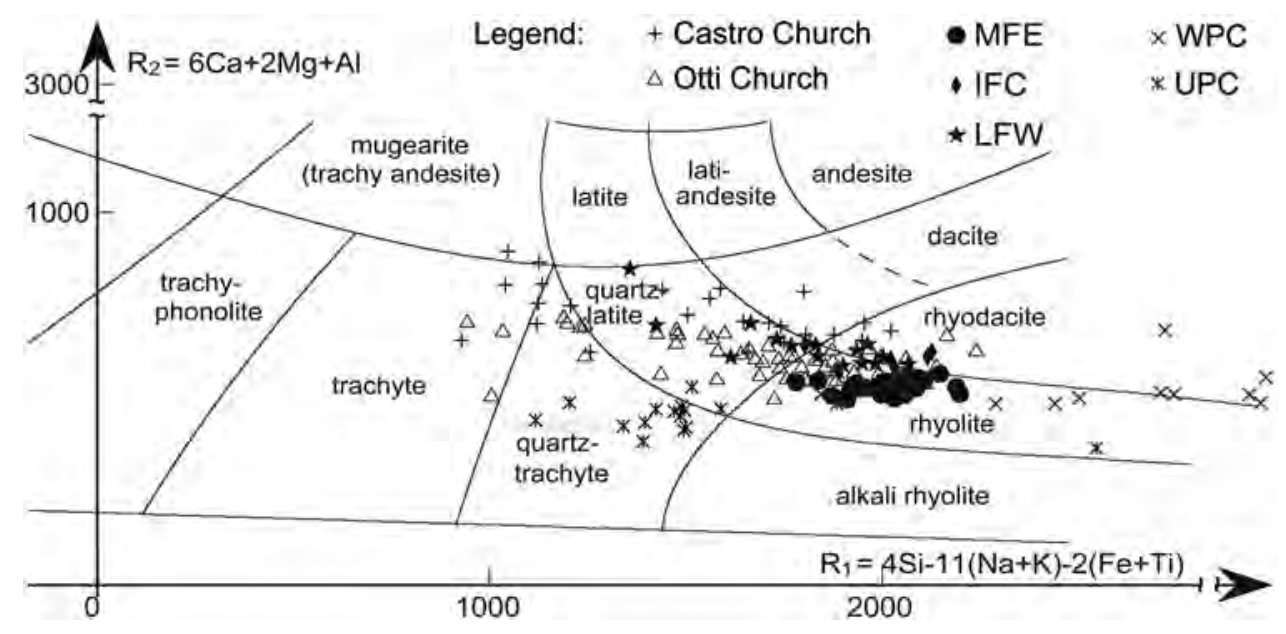

Figure 7. $R_{1}$ vs. $R_{2}$ classification diagram of De La Roche et al. (1980, modified) with volcanic samples from the Oschiri sector and Santa Maria Otti Church. Graphic symbols: crosses = samples from Castro Church; empty triangles = samples from nearby Otti Church; black circles = outcrop MFE samples from Oschiri sector; rhombus = IFC samples from Oschiri sector; stairs $=$ outcrop LFW samples from Oschiri sector; $\times=$ outcrop WPC samples from Chilivani/Tula sector; $*=$ outcrop UPC samples from Chilivani/ Tula sector. 

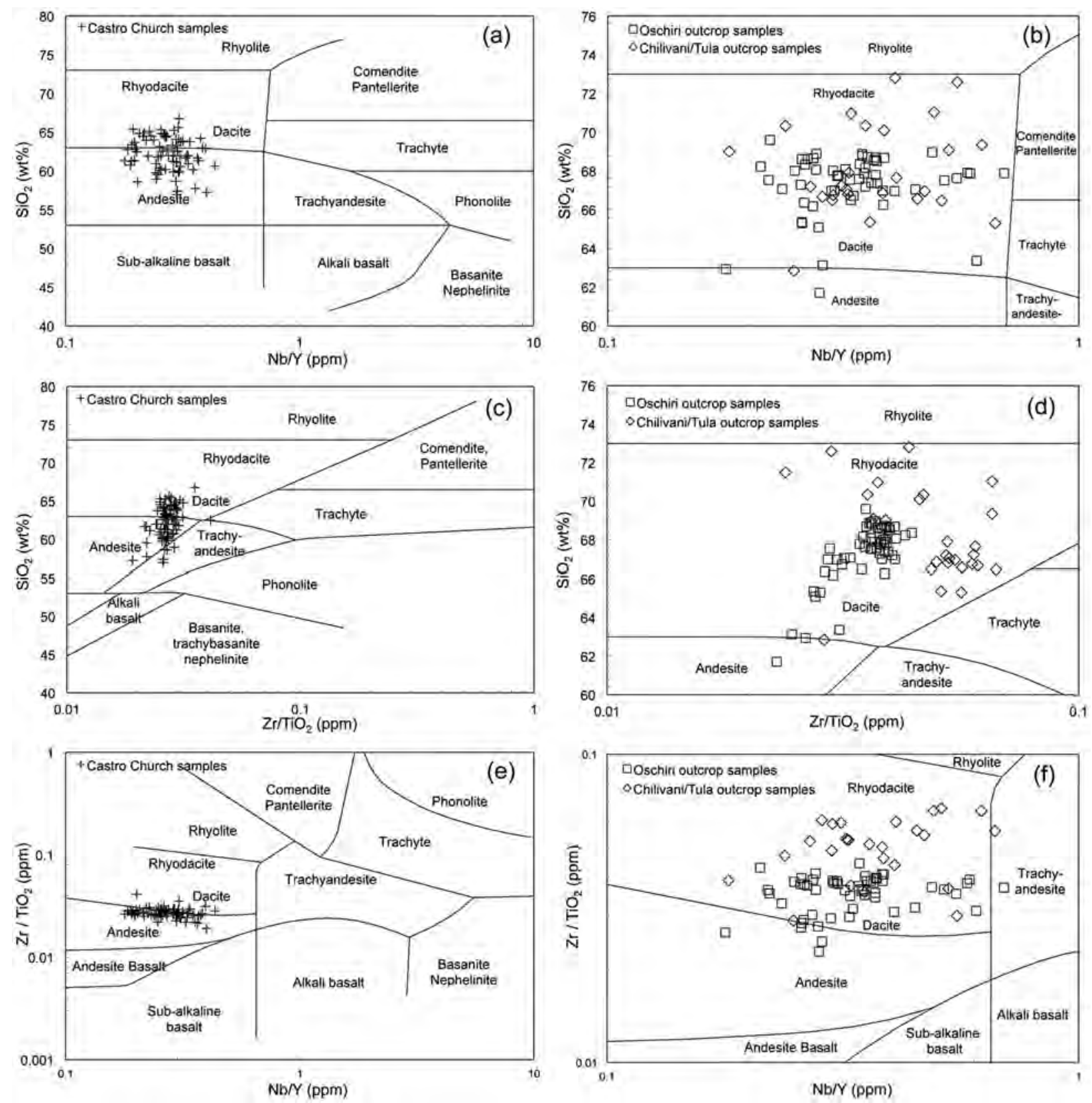

Figure 8. Chemical classification of volcanic samples from the Nostra Signora di Castro Cathedral and outcrops from Oschiri and Chilivani/Tula sectors, according to the different diagrams of Winchester and Floyd (1977, modified). (a, b) $\mathrm{Nb} / \mathrm{Y}$ (ppm) versus $\mathrm{SiO}_{2}$ (wt\%); (c, d) $\mathrm{Zr} / \mathrm{TiO}_{2}$ (ppm) versus $\mathrm{SiO}_{2}$ (wt\%); (e, f) $\mathrm{Nb} / \mathrm{Y}$ (ppm) versus $\mathrm{Zr} / \mathrm{TiO}_{2}$ (ppm). Graphic symbols: crosses = Castro Church samples; squares = outcrop samples from Oschiri sector; rhombus=outcrop samples from Chilivani/Tula sector (WPC, UPC pyroclastics).

elongated and flattened, and often include crystals having homogeneous composition.

The intermediately-fractionated central pyroclastites (IFC) show petrographic characteristics that lie between the two other groups (Table 1; Figure 5(ad)). They have a prophyritic index ranging between 10 and 14 , with a colour index of about 5 . The phenocryst paragenesis consists of first- or second-generation plagioclases in more or less equal ratios, microphenocrystals of Ti-magnetite, rare clinopyroxenes, very rare sanidine \pm apatite \pm quartz \pm biotite. In these pyroclastic rocks, the lithic fragments are rare, show a basicintermediate composition and are slightly rounded.
Pumices are more abundant with respect to LFW samples and are only slightly flattened and elongated.

The more-fractionated eastern pyroclastites (MFE) show an average porphyritic index around to 13 and a colour index around 4 (Table 1 ; Figure $5(\mathrm{~g}, \mathrm{~h})$ ). The phenocryst assemblage is made up of plagioclases, those of the last generation being most common, microphenocrystals of Ti-magnetite \pm clinopyroxene \pm apatite \pm sanidine \pm quartz \pm biotite. Lithic fragments, rare or sometimes absent, have sharp or slightly rounded edges, and are sometimes of subvolcanic origin. Pumices are more abundant than in LFW samples; they are flattened and more elongated. 
The WPC rocks of Chilivani-Tula sector show variable petrographic features (Table 1), even within the same cooling unit. They have a porphyritic index between $5 \%$ and $15 \%$ for phenocrystals (in order of segregation) of spinel, plagioclase, \pm orthopyroxene, clinopyroxene, K-feldspar, quartz, and very rare horneblende. There are angular or rounded cognate fragments (2-7\%). Nodules of gabbro and granoblastic rock fragments of the basement are occasionally present. The UPC rocks show variable compositional characteristics due to the different presence of the phenocrystals and pumice and lithic components. The phenocrystals are plagioclases, \pm orthopyroxene, clinopyroxene, \pm biotite, K-feldspar, and quartz. Biotite is often deformed and partially transformed in chlorite minerals.

\section{Geochemical characteristics and rock classification}

The results of XRF chemical analysis of the volcanic outcrops from the Oschiri and Chilivani/Tula sectors are shown in the Tables 5 and 6, respectively.

The whole-rock geochemical composition of an ignimbrite deposit can be remarkably different from magma composition and can vary across the deposit as a consequence of the eruption and emplacement dynamics of these volcanic products. Nevertheless, for the purposes of this research the major and trace element chemical composition of the ignimbrite outcrops can be very useful for a comparison with the rocks used in the Church of Nostra Signora di Castro, and with this finality the chemical analyses are reported in geochemical classification diagrams.

On the base of geochemical data, some differences emerged between the different volcanic facies and defined sectors. The WPC rocks of Chilivani/Tula and the pyroclastites of Oschiri exhibit, on average, higher $\mathrm{TiO}_{2}, \mathrm{Al}_{2} \mathrm{O}_{3}, \mathrm{FeO}_{\text {tot}}$, and $\mathrm{Na}_{2} \mathrm{O}$ and lower $\mathrm{K}_{2} \mathrm{O}$ contents than the UPC as well as slightly lower $\mathrm{Zr}, \mathrm{Nb}, \mathrm{Y}, \mathrm{La}$, and Ce concentrations.

The magmatic evolution of volcanics and their geochemical/geographic distributions in the Oschiri and Chilivani/Tula sectors are shown in the D.I. vs $\mathrm{TiO}_{2}$ diagram (Figure 9, D.I. = differentation index of Thornton and Tuttle (1960). The WPC (welded pyroclastites from the M. Sassu area) align with the trend of the most eastern volcanics (LFW, IFC, MFE) from the Oschiri sector. According to this latter diagram and the classification diagram of De La Roche et al. (1980), the volcanics from the two sectors show the following characteristics.

As regards the Oschiri sector: the LFW pyroclastics (western zone) have a D.I. range of $\sim 70-78$ (Tables 1 and 5; Figure 9) and they are mainly classified as rhyolite and quartz-latite and as subordinate rhyodacite (Figure 7); the IFC pyroclastics (central zone) show a D.I. range of $\sim 76-79$ (Tables 1 and 5; Figure 9) and they are mainly classified (according to De La Roche et al. diagram (1980)) as rhyolite and rhyodacite and as subordinate quartz-latite (Figure 7); the MFE pyroclastics (eastern zone) have a D.I. of 77-82 (Tables 1 and 5; Figure 9) and they are classified as rhyolites (Figure 7).

According to Columbu (2017), the WPC rocks of the Chilivani/Tula sector (including the lava-like ignimbrites), normally outcrop further to the NE with respect to the UPC rocks, showing a D.I. range of 284-88 (Tables 1 and 6), are the most fractionated ones in the area and complete the trend displayed by products from the Oschiri sector (Figure 9). They are mainly classified as quartz-trachytes, and subordinately as quartz-latites and rhyolites (Figure 7). The UPC rocks have a D.I. range of $\sim 70-83$ (Tables 1 and 6). Comparing the samples with same D.I., they show with respect to WPC rocks (Figure 9) significantly lower $\mathrm{TiO}_{2}, \mathrm{Al}_{2} \mathrm{O}_{3}$ $\mathrm{FeO}_{\mathrm{t}}, \mathrm{MgO}, \mathrm{Na}_{2} \mathrm{O}, \mathrm{P}_{2} \mathrm{O}_{5}, \mathrm{Zn}, \mathrm{Zr}, \mathrm{Nb}$, and $\mathrm{Y}$ content, and higher $\mathrm{SiO}_{2}$, L.O.I. and $\mathrm{Sr}$ content (Table 6). They are mainly classified as rhyodacites and subordinately as rhyolites (Figure 7).

Observing the other classification diagrams, according to Total Alkali Silica of Le Maitre et al. (2002), the outcrop samples of Oschiri sector mainly show a trachydacitic or dacitic composition, similarly to those of the Church of Nostra Signora di Castro (Figure 6(b)). The samples of Chilivani/Tula sector show two different populations: the samples classified as trachydacite falling into the alkaline series, and the samples classified as dacite and rhyolite falling into the subalkaline series (Figure 6(b)).

According to the Wincester and Floyd diagram (1977) (Figure 8(b)) the volcanics of Oschiri and Chilivani/Tula outcrops show a dacitic and rhyodacitic composition.

\section{Mineralogical and chemical investigations on alteration}

The study of the alteration processes of the Church's volcanics has been dealt on the mineralogical basis, through optical polarised microscopy (OM) of thin sections and XRD / SEM-EDX analysis, in order to investigate the presence of accessory and / or secondary phases not recognisable at the polarising microscope. Then, on a chemical basis, a data comparison between the outer sample (signed with $\mathrm{A}^{+}$) taken on the external surface of the monument rock (presumably more altered) and the inner 'fresh' sample $\left(A^{-}\right)$ was made.

\section{OM / SEM-EDX / XRD analyses}

By optical microscopy analysis, the groundmass glass of the ignimbritic samples is often transformed in hardly recognisable cryptocrystalline minerals, revealing devitrification processes (Figure 5) with the 
Table 5. Chemical analysis of selected volcanics from Oschiri sector.

\begin{tabular}{|c|c|c|c|c|c|c|c|c|c|c|c|c|c|c|c|c|c|c|c|c|c|c|c|c|c|}
\hline $\begin{array}{l}\text { Sample } \\
\text { Subsig. }\end{array}$ & $\begin{array}{c}1 \\
\mathrm{CO} 3 \\
\mathrm{~A}^{-}\end{array}$ & $\begin{array}{c}2 \\
\mathrm{CO} 3 \\
\mathrm{~A}+\end{array}$ & $\begin{array}{c}3 \\
\mathrm{CO} 5 \\
\mathrm{~A}^{-}\end{array}$ & $\begin{array}{c}4 \\
\mathrm{CO} 5 \\
\mathrm{~A}+\end{array}$ & $\begin{array}{c}5 \\
\text { CO6 } \\
A^{-}\end{array}$ & $\begin{array}{c}6 \\
\text { CO18a } \\
A^{-}\end{array}$ & $\begin{array}{c}7 \\
\mathrm{CO} 18 \mathrm{a} \\
\mathrm{A}+\end{array}$ & $\begin{array}{c}8 \\
0136 \mathrm{~b} \\
\mathrm{~A}^{-}\end{array}$ & $\begin{array}{c}9 \\
0136 b \\
A^{-}\end{array}$ & $\begin{array}{c}10 \\
\text { CO197 } \\
A^{-}\end{array}$ & $\begin{array}{c}11 \\
\mathrm{CO} 210 \\
\mathrm{~A}^{-}\end{array}$ & $\begin{array}{c}12 \\
\mathrm{CO}^{1211} \\
\mathrm{~A}^{-}\end{array}$ & $\begin{array}{c}13 \\
\mathrm{CO} 212 \\
\mathrm{~A}^{-}\end{array}$ & $\begin{array}{c}14 \\
\mathrm{CO}^{222} \\
\mathrm{~A}^{-}\end{array}$ & $\begin{array}{c}15 \\
\mathrm{CO} 1 \\
\mathrm{~A}^{-}\end{array}$ & $\begin{array}{c}16 \\
\mathrm{CO} 1 \\
\mathrm{~A}+\end{array}$ & $\begin{array}{c}17 \\
\mathrm{CO} 2 \\
\mathrm{~A}^{-}\end{array}$ & $\begin{array}{c}18 \\
\mathrm{CO} 2 \mathrm{~A} \\
\mathrm{~A}+\end{array}$ & $\begin{array}{c}19 \\
\mathrm{CO} 2 \mathrm{~A} \\
\mathrm{~A}+\end{array}$ & $\begin{array}{c}20 \\
\mathrm{CO} 8 \\
\mathrm{~A}^{-}\end{array}$ & $\begin{array}{c}21 \\
\mathrm{CO} 14 \\
\mathrm{~A}^{-}\end{array}$ & $\begin{array}{c}22 \\
\mathrm{CO} 199 \\
\mathrm{~A}^{-}\end{array}$ & $\begin{array}{c}23 \\
\mathrm{CO} 199 \\
\mathrm{~A}+\end{array}$ & $\begin{array}{c}24 \\
\mathrm{CO} 221 \\
\mathrm{~A}^{-}\end{array}$ & $\begin{array}{c}25 \\
\mathrm{CO} 221 \\
\mathrm{~A}^{-}\end{array}$ \\
\hline Class. & qzLt & qzLt & qzLt & qzLt & qzLt & RyDc & RyDc & qzLt & RyDc & qzLt & RyDc & RyDc & qzLt & qzLt & Ry & Ry & qzLt & qzLt & qzLt & Ry & RyDc & RyDc & RyDc & Ry & Ry \\
\hline $\mathrm{SiO}_{2}$ & 63.13 & 63.81 & 65.30 & 64.14 & 61.71 & 66.26 & 67.67 & 65.09 & 66.72 & 62.94 & 65.10 & 65.84 & 65.57 & 63.37 & 66.18 & 65.65 & 65.36 & 64.91 & 64.99 & 67.79 & 67.07 & 67.05 & 66.27 & 66.97 & 66.98 \\
\hline $\mathrm{TiO}_{2}$ & 0.76 & 0.73 & 0.72 & 0.64 & 0.84 & 0.68 & 0.68 & 0.74 & 0.67 & 0.73 & 0.74 & 0.73 & 0.74 & 0.71 & 0.70 & 0.66 & 0.70 & 0.65 & 0.70 & 0.68 & 0.68 & 0.69 & 0.71 & 0.70 & 0.69 \\
\hline $\mathrm{Al}_{2} \mathrm{O}_{3}$ & 14.95 & 14.75 & 14.72 & 12.88 & 14.77 & 14.82 & 14.38 & 15.16 & 14.04 & 14.34 & 14.32 & 14.41 & 14.55 & 15.61 & 14.22 & 14.09 & 14.58 & 14.43 & 14.67 & 14.27 & 14.41 & 14.95 & 14.69 & 14.51 & 14.47 \\
\hline $\mathrm{Fe}_{2} \mathrm{O}_{3}$ & 5.32 & 5.05 & 4.93 & 6.66 & 5.64 & 4.94 & 4.16 & 5.06 & 4.24 & 5.41 & 5.56 & 5.65 & 5.20 & 5.28 & 4.79 & 4.92 & 5.12 & 4.73 & 4.68 & 4.62 & 4.95 & 4.34 & 4.32 & 4.95 & 4.64 \\
\hline $\mathrm{FeO}$ & 0.16 & 0.28 & 0.54 & 0.97 & 0.48 & 0.46 & 0.47 & 0.66 & 1.01 & 0.23 & 0.42 & 0.43 & 0.30 & 0.24 & 0.61 & 0.65 & 0.25 & 0.39 & 0.35 & 0.26 & 0.44 & 0.23 & 0.59 & 0.21 & 0.42 \\
\hline $\mathrm{MnO}$ & 0.12 & 0.13 & 0.10 & 0.14 & 0.12 & 8.00 & 7.00 & 0.12 & 0.12 & 0.10 & 6.00 & 6.00 & 8.00 & 0.14 & 0.13 & 0.15 & 0.12 & 0.11 & 0.12 & 6.00 & 9.00 & 0.11 & 0.13 & 8.00 & 9.00 \\
\hline $\mathrm{MgO}$ & 0.99 & 0.89 & 1.11 & 1.75 & 1.30 & 0.85 & 0.58 & 0.66 & 1.01 & 1.33 & 1.16 & 0.85 & 1.02 & 0.85 & 0.78 & 0.83 & 0.79 & 0.95 & 0.76 & 0.63 & 0.75 & 0.68 & 0.79 & 0.68 & 0.68 \\
\hline $\mathrm{CaO}$ & 3.31 & 3.10 & 2.78 & 2.35 & 3.25 & 2.62 & 2.74 & 2.93 & 2.81 & 4.67 & 2.86 & 2.85 & 2.89 & 2.91 & 2.76 & 2.68 & 2.68 & 2.70 & 2.85 & 2.53 & 2.66 & 2.48 & 2.62 & 2.59 & 2.58 \\
\hline $\mathrm{Na}_{2} \mathrm{O}$ & 3.21 & 3.02 & 3.81 & 2.86 & 2.92 & 3.71 & 4.13 & 3.80 & 3.69 & 4.86 & 3.26 & 3.57 & 3.75 & 3.46 & 3.73 & 3.84 & 3.18 & 3.19 & 3.18 & 4.04 & 3.97 & 3.84 & 3.79 & 3.76 & 3.73 \\
\hline $\mathrm{K}_{2} \mathrm{O}$ & 6.35 & 6.42 & 4.58 & 5.53 & 5.27 & 4.02 & 4.02 & 4.36 & 3.66 & 4.06 & 4.48 & 4.33 & 4.48 & 4.72 & 4.67 & 4.28 & 6.23 & 5.92 & 5.95 & 3.88 & 3.77 & 3.86 & 3.89 & 4.40 & 4.31 \\
\hline P2O5 & 0.58 & 0.46 & 0.21 & 0.19 & 0.26 & 0.15 & 0.16 & 0.22 & 0.18 & 0.27 & 0.62 & 0.27 & 0.30 & 0.23 & 0.24 & 0.28 & 0.28 & 0.31 & & 0.17 & 0.18 & 0.19 & 0.20 & 0.38 & 0.30 \\
\hline L.O.I. & 1.12 & 1.37 & 1.20 & 1.89 & 3.44 & 1.41 & 0.93 & 1.18 & 1.83 & 1.06 & 1.43 & 1.02 & 1.12 & 2.49 & 1.19 & 1.96 & 0.71 & 1.70 & 1.30 & 1.08 & 1.03 & 1.57 & 2.00 & 0.77 & 1.11 \\
\hline Total & 100.00 & 1001.00 & 100.00 & 100.00 & 100.00 & 100.00 & 99.99 & 99.98 & 99.98 & 100.00 & 1001.00 & 1001.00 & 100.00 & 1001.00 & 100.00 & 99.99 & 100.00 & 99.99 & 99.99 & 1001.00 & 100.00 & 99.99 & 100.00 & 100.00 & 100.00 \\
\hline S.I. & 9.38 & 8.62 & 11.68 & 17.26 & 13.70 & 9.91 & 6.64 & 7.48 & 12.08 & 12.98 & 13.03 & 9.71 & 11.03 & 9.41 & 8.50 & 9.27 & 7.74 & 9.44 & 7.68 & 7.37 & 8.83 & 8.11 & 9.33 & 7.69 & 7.80 \\
\hline Mg Val. & 0.26 & 0.25 & 0.28 & 0.31 & 0.29 & 0.24 & 0.20 & 0.18 & 0.27 & 0.32 & 0.28 & 0.22 & 0.27 & 0.23 & 0.22 & 0.23 & 0.22 & 0.27 & 0.23 & 0.20 & 0.21 & 0.23 & 0.24 & 0.21 & 0.21 \\
\hline A.l. & 0.81 & 0.81 & 0.76 & 0.83 & 0.71 & 0.71 & 0.77 & 0.72 & 0.71 & 0.86 & & 0.73 & 0.76 & 0.69 & 0.79 & 0.78 & 0.82 & 0.81 & & 0.76 & 0.74 & 0.70 & 0.71 & 0.75 & 0.75 \\
\hline Q & 11.38 & 13.13 & 16.26 & 15.78 & 13.71 & 19.94 & 20.34 & 16.90 & 21.72 & 8.35 & 19.67 & 19.01 & 17.41 & 15.32 & 18.09 & 18.26 & 14.92 & 15.40 & 15.68 & 21.44 & 20.67 & 21.74 & 20.49 & 20.17 & 20.56 \\
\hline C & 0.00 & 0.00 & 0.00 & 0.00 & 0.00 & 0.00 & 0.00 & 0.00 & 0.00 & 0.00 & 0.39 & 0.00 & 0.00 & 7.00 & 0.00 & 0.00 & 0.00 & 0.00 & 0.00 & 0.00 & 0.00 & 0.40 & 0.00 & 0.00 & 0.00 \\
\hline Or & 37.52 & 37.94 & 27.06 & 32.68 & 31.14 & 23.75 & 23.75 & 25.76 & 21.63 & 23.99 & 26.47 & 25.59 & 26.47 & 27.89 & 27.60 & 25.29 & 36.81 & 34.98 & 35.16 & 22.93 & 22.28 & 22.81 & 22.99 & 26.00 & 25.47 \\
\hline$A b$ & 27.16 & 25.55 & 32.24 & 24.20 & 24.71 & 31.39 & 34.94 & 32.15 & 31.22 & 41.12 & 27.58 & 30.21 & 31.73 & 29.28 & 31.56 & 32.49 & 26.91 & 26.99 & 26.91 & 34.18 & 33.59 & 32.49 & 32.07 & 31.81 & 31.56 \\
\hline An & 7.63 & 7.73 & 9.54 & 5.97 & 11.63 & 11.91 & 8.83 & 11.43 & 10.94 & 5.32 & 10.14 & 10.51 & 9.64 & 12.93 & 8.27 & 8.57 & 7.11 & 7.57 & & 9.34 & 10.36 & 11.06 & 11.58 & 9.72 & 101.00 \\
\hline $\mathrm{Di}$ & 30 & 1.14 & 0.80 & 1.28 & 0.81 & 2.00 & 0.76 & 0.31 & 0.48 & 4.94 & 0.0 & 0.40 & 0.73 & 0.00 & 0.8 & 0.64 & 0.98 & 0.99 & 0 & 0.44 & 0.36 & 0.00 & 3.00 & 0.14 & 0.18 \\
\hline $\mathrm{Ed}$ & & & 1.65 & 2.49 & & 7.00 & & & 1.07 & 8.68 & & 1.20 & 1.61 & & 2. & 1.8 & 2.7 & 2.2 & & 1. & & & & 0.42 & 0.54 \\
\hline $\mathrm{SI}$ & 4.27 & 3.97 & 2.45 & 3.7 & 2.37 & 9.00 & 3.21 & 1.4 & 1.56 & 13.62 & 0. & 1.61 & 2.34 & 0.00 & 3.3 & 2.49 & 3.74 & 3.24 & 2.6 & 1.81 & 1.42 & 0.00 & 9.00 & 0.56 & 0.71 \\
\hline En & 1. & 1. & 2.39 & 3.7 & 2.86 & 2.11 & 1.09 & 1.5 & 2.29 & 1.0 & & 1.93 & 2.2 & & 1. & 1.7 & 1.5 & 1.9 & & 1. & 1.70 & & 1.96 & 1.63 & 1.61 \\
\hline $\mathrm{Fs}$ & & & 5.63 & 8 & 6. & 6.39 & 4. & & 5.82 & & & 6.58 & 5.58 & & & 5.8 & 4.9 & 4.9 & & 4. & 5.86 & & & & 5.67 \\
\hline Hy & 6.72 & 6.49 & 8.02 & 12.1 & 9.25 & 8.50 & 5.15 & 7.7 & 8.12 & 3.08 & 9.96 & 8.5 & 7.79 & 8.7 & 6.74 & 7.6 & 6.4 & 6.85 & 6.4 & 6.29 & 7.56 & 7.00 & 7.74 & 7.44 & 7.29 \\
\hline $\mathrm{Mt}$ & & & 0.95 & & 1.06 & 0.94 & & 1. & 0.92 & & 1. & 1.0 & 0.95 & & & 0.9 & 0.9 & 0.8 & & 0.8 & & & & 0.89 & 0.88 \\
\hline ॥ & 1.44 & 1.39 & 1.37 & 1.22 & 1.60 & 1.29 & 1. & 1.41 & 1.27 & 1.39 & 1. & 1.39 & 1.41 & & 1.3 & 1.25 & 1.33 & 1.23 & 1. & 1.29 & 1.29 & & 1. & 1.33 & 1.31 \\
\hline Ap & 1.34 & 1.07 & 0.49 & 0.44 & 0.60 & 0.35 & 0. & 0.51 & 0.42 & 0 & & 0.63 & 0.69 & & 0.56 & 0.65 & 0.65 & 0.72 & & 0.39 & 0.42 & 0 & 0.46 & 0.88 & 0.69 \\
\hline D.I. & 76.06 & 76.62 & 75.56 & 72.65 & 69.56 & 75.08 & 79.04 & 74.81 & 74.57 & 73.4 & 73 & 74.80 & 75.61 & 72.4 & 77.24 & 76.04 & 78.64 & 77.37 & 77. & 78.55 & 76.54 & 77.04 & 75.54 & 77.98 & 77.59 \\
\hline SAL & 83.69 & 84.35 & 85.09 & 78.63 & 81.19 & 87.00 & 87.87 & 86.24 & 85.50 & 78.78 & 84.2 & 85.31 & 85.25 & 85.49 & 85.51 & 84.61 & 85.75 & 84.94 & 85. & 87.90 & 86.91 & 88.50 & 87.12 & 87.70 & 87.60 \\
\hline FEM & & 13 & 13.28 & 18.91 & 14.88 & 11.17 & 10.83 & 12.12 & 12.29 & 19.69 & 13.84 & 13.19 & 13.18 & 11.57 & 12.89 & 13.00 & 13.09 & 12.94 & 12.35 & 10.63 & 11.63 & 9.54 & 10.51 & 11.10 & 10.89 \\
\hline V & 53.0 & 53.3 & 52.6 & 49.1 & 59.8 & 21.7 & 26.3 & 47.9 & 30.2 & 54.4 & 51.1 & 53.2 & 54.8 & 34.3 & 39.0 & 43.0 & 49.8 & 42.5 & 47.1 & 31.7 & 33.8 & 46.4 & 37.1 & 46.1 & 40.0 \\
\hline $\mathrm{Ni}$ & 4.0 & 6.6 & 4.8 & 5.7 & 3.4 & 5.7 & 5.8 & 4.3 & 4.7 & 4.9 & 5 & 6.5 & 5.1 & 5.8 & 4.4 & 4.5 & 5.7 & 5.1 & 5.9 & 3.3 & 3.3 & 5.2 & 4.7 & 4.1 & 3.7 \\
\hline $\mathrm{Zn}$ & 68.1 & 65.8 & 75.6 & 75.7 & 89.5 & 84.2 & 92.2 & 68.2 & 77.0 & 79.0 & 117.0 & 71.4 & 94.9 & 146.0 & 73.8 & 79.3 & 60.5 & 51.9 & 54.3 & 87.9 & 78.7 & 65.9 & 85.2 & 75.1 & 72.4 \\
\hline $\mathrm{Rb}$ & 141 & 146 & 183 & 305 & 86.8 & 68.7 & 121 & 114 & 121 & 89 & 156 & 121 & 166 & 56.1 & 161 & 157 & 156 & 136 & 150 & 137 & 134 & 134 & 125 & 141 & 136 \\
\hline $\mathrm{Sr}$ & & & & & 373 & & 223 & 223 & & & & 18 & & & & & & & 1 & & & & & 235 & 214 \\
\hline $\mathrm{Ba}$ & 488 & 503 & 53 & 53 & 58 & 63 & 606 & 589 & 575 & 51 & 5 & 593 & & 6 & 530 & 581 & 473 & 498 & 5 & 5 & & 606 & 99 & & 621 \\
\hline $\mathrm{Zr}$ & 188 & 178 & 204 & 191 & 192 & 264 & 251 & 205 & 211 & 192 & 197 & 190 & 217 & 221 & 211 & 206 & 192 & 174 & 183 & 234 & 223 & 220 & 209 & 215 & 203 \\
\hline $\mathrm{Pb}$ & n.d. & 25.9 & 17.8 & 15.1 & 45.5 & 20.0 & 32.5 & n.d. & 22.1 & 20.9 & 32.9 & n.d. & 29.7 & 36.3 & 24.4 & n.d. & n.d. & n.d. & 13.6 & 18.3 & 12.5 & 15.9 & 23.8 & 20.6 & n.d. \\
\hline $\mathrm{Nb}$ & 12.6 & 9.9 & 10.6 & 10.9 & 10.5 & 14.8 & 13.2 & 12.3 & 10.9 & 5.7 & 12 & 8.2 & 9.6 & 12 & 11 & 12.1 & 10.5 & 8.7 & 7.4 & 12.0 & 9.9 & 13.0 & 8.3 & 14.3 & 10.8 \\
\hline $\mathrm{Y}$ & 44.1 & & 41.0 & 44.2 & 37.3 & & 53.2 & 43 & 32.8 & 32.0 & 37 & 36.4 & 44.3 & 21 & 43 & 45. & 40.7 & 33.9 & 37.4 & 32.4 & 42.2 & 28.9 & 25.7 & 35.2 & 36.2 \\
\hline La & 37.4 & 30.6 & 22.4 & 17.7 & 26.8 & 39.6 & 38.1 & 25.9 & 30.5 & 31.0 & 30.4 & 30.0 & 36.3 & 26.4 & 34.4 & 32.2 & 27.0 & 35.7 & 29.7 & 23.8 & 31.7 & 25.7 & 23.9 & 24.4 & 24.4 \\
\hline $\mathrm{Ce}$ & 53.9 & 48.9 & 38.5 & 36.1 & 58.7 & 52.6 & 61.6 & 52.4 & 42.0 & 53.6 & 62.4 & 48.4 & 64.9 & 39.8 & 56.0 & 52.8 & 55.4 & 49.4 & 56.0 & 44.9 & 63.6 & 40.6 & 47.5 & 44.7 & 54.0 \\
\hline
\end{tabular}

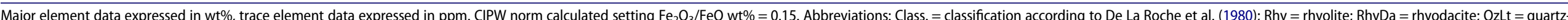

latite; OzTr = quartz-trachyte; $\operatorname{Tr}=$ trachyte; A.I = agpaitic index of Shand (1951); D.I. = normative Quartz + Albite + Orthoclase + Nepheline + Kaliophilite + Leucite, differentiation index of Thornton and Tuttle (1961); n.d. = not detected. 
Table 6. Chemical analysis of selected volcanics from Chilivani/Tula sector.

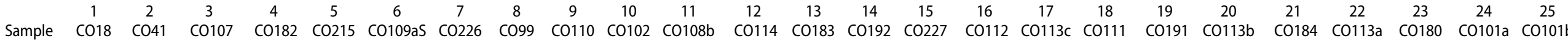

\begin{tabular}{|c|c|c|c|c|c|c|c|c|c|c|c|c|c|c|c|c|c|c|c|c|c|c|c|c|c|}
\hline Subsig. & $\mathrm{A}^{-}$ & $\mathrm{A}^{-}$ & $\mathrm{A}^{-}$ & $\mathrm{A}^{-}$ & $\mathrm{A}^{-}$ & $\mathrm{A}^{-}$ & $\mathrm{A}^{-}$ & $A^{-}$ & $\mathrm{A}^{-}$ & $\mathrm{A}^{-}$ & $\mathrm{A}^{-}$ & $\mathrm{A}^{-}$ & $\mathrm{A}^{-}$ & $\mathrm{A}^{-}$ & $A^{-}$ & $\mathrm{A}^{-}$ & $\mathrm{A}^{-}$ & $\mathrm{A}^{-}$ & $\mathrm{A}^{-}$ & $\mathrm{A}^{-}$ & $\mathrm{A}^{-}$ & $\mathrm{A}^{-}$ & $A^{-}$ & $\mathrm{A}^{-}$ & $\mathrm{A}^{-}$ \\
\hline Class. & Ry & qzTr & qzTr & qzTr & qzTr & qzTr & qzTr & qzTr & qzTr & qzLt & qzTr & Ry & RyDc & Ry & RyDc & Ry & Ry & Ry & RyDc & RyDc & RyDc & RyDc & RyDc & RyDc & RyDc \\
\hline $\mathrm{SiO}_{2}$ & 65.85 & 66.81 & 67.20 & 62.85 & 66.49 & .05 & 65.37 & 66.57 & 66.96 & 67.91 & 66.47 & 72.81 & 67.04 & 65.30 & 71.03 & 69.35 & 69.08 & 72.59 & 69.63 & 70.34 & 71.49 & 69.01 & 70.97 & 70.33 & 70.10 \\
\hline $\mathrm{TiO}_{2}$ & 0.56 & 0.55 & 0.55 & 0.55 & 0.54 & 0.54 & 0.53 & 0.52 & 0.52 & 0.50 & 0.45 & 0.42 & 0.38 & 0.38 & 0.32 & 0.31 & 0.30 & 0.29 & 0.29 & 0.28 & 0.28 & 0.27 & 0.24 & 0.23 & 0.21 \\
\hline $\mathrm{Al}_{2} \mathrm{O}_{3}$ & 15.99 & 15.11 & 15.16 & 16.61 & 15.82 & 14.90 & 15.90 & 15.31 & 15.41 & 14.47 & 15.70 & 12.30 & 14.55 & 15.42 & 13.23 & 13.61 & 13.45 & 11.46 & 12.83 & 13.87 & 12.10 & 14.01 & 11.97 & 12.65 & 12.31 \\
\hline $\mathrm{Fe}_{2} \mathrm{O}_{3}$ & 4.35 & 3.83 & 3.79 & 4.10 & 3.56 & 3.40 & 4.33 & 3.38 & 3.68 & 3.74 & 2.85 & 2.81 & 3.38 & 3.00 & 2.21 & 2.15 & 2.64 & 1.97 & 2.42 & 2.52 & 2.31 & 1.77 & 2.44 & 1.52 & 1.62 \\
\hline $\mathrm{FeO}$ & 0.12 & 0.56 & 0.32 & 0.14 & 0.36 & 0.69 & 0.22 & 0.70 & 0.43 & 0.35 & 0.58 & 0.44 & 0.33 & 0.35 & 0.34 & 0.57 & 1.38 & 0.70 & 0.21 & 0.90 & 0.43 & 0.81 & 0.27 & 0.82 & 0.50 \\
\hline $\mathrm{MnO}$ & 7.00 & 7.00 & 10 & 6.00 & 6.00 & 8.00 & 7.00 & 5.00 & 0.11 & 0.10 & 0.10 & 3.00 & 7.00 & 8.00 & 0.13 & 8.00 & 4.00 & 0.10 & 6.00 & 4.00 & 5.00 & 4.00 & 4.00 & 4.00 & 7.00 \\
\hline $\mathrm{MgO}$ & 0.55 & 0.29 & 0.38 & 1.03 & 0.30 & 0.4 & 0.40 & 0.31 & 0.29 & 0.3 & 0.1 & 0.23 & 1.70 & 0.89 & 0.94 & 1.00 & 1.31 & 0.70 & 1.39 & 1.43 & 1.05 & 1.23 & 1.20 & & 1.20 \\
\hline $\mathrm{CaO}$ & 1.40 & 1.44 & 1.49 & 0.60 & 1.36 & 1.32 & 1.4 & 0.99 & 1.39 & 1.6 & 0.64 & 1.07 & 2.92 & 1.54 & 1.70 & 1.58 & 1.61 & 1.65 & 1.97 & 2.00 & 2.11 & 1.67 & .16 & & 1.96 \\
\hline $\mathrm{Na}_{2} \mathrm{O}$ & 2.79 & 4.02 & & & 3.60 & & 3.9 & 3.59 & 3.91 & 3. & 3.0 & 2.57 & 2.23 & 1.17 & 1.0 & 1.3 & 1.5 & 1.54 & 1.9 & 1.3 & 1.5 & 1.3 & & & 2.07 \\
\hline $\mathrm{K}_{2} \mathrm{O}$ & 93 & 6.10 & 6.02 & 11.17 & 6.90 & 6.57 & 6.96 & 6.60 & 6.26 & $6 . C$ & 7.9 & 5.56 & 3.65 & 8.54 & 5.6 & 7.6 & 6.23 & 4.32 & 3.7 & 4.8 & 3.58 & 5.6 & & & 4.85 \\
\hline P205 & & & & & 0.16 & & & 5.00 & 9.00 & 0. & & 0.19 & 6.00 & 6.00 & $6 . C$ & 8.0 & 4.0 & 5.0 & $7 .($ & 6.0 & & & & & 0.11 \\
\hline L.O.I. & 2.26 & 1.08 & 0.75 & 1.83 & 0.85 & 1.0 & 0.68 & 1.92 & 0.95 & 0.78 & 1.93 & 1.58 & 3.69 & 3.27 & 3.33 & 2.31 & 2.41 & 4.63 & 5.51 & 2.35 & 4.91 & 4.06 & .91 & & 4.99 \\
\hline Total & 100.00 & 99.99 & 001.00 & 1001.00 & 100.00 & 99.9 & 99.98 & 99.99 & 100.00 & 100.0 & 99.99 & 001.00 & 100.00 & 100.00 & 100.00 & 100.00 & 99.99 & 100.00 & 1001.00 & 99.99 & 1001.00 & 99.9 & 100.00 & 100. & 99.99 \\
\hline S.I. & 5.93 & & 3.61 & & & & & 2.95 & 2.77 & 3.1 & 1.52 & 2.75 & 22.43 & 8.40 & 12.29 & 104.00 & 14.49 & 10.67 & & 18.74 & 16. & 14. & & 12. & 14.78 \\
\hline Mg Val. & 0. & & & & & & & & & & & & & 0.34 & & & 0.3 & 0.34 & & 0. & & & & & 0.52 \\
\hline A.I. & 0.69 & 0.87 & $0 . \varepsilon$ & & 0.85 & 0.8 & 0.8 & 0.85 & 0.86 & 0.90 & $0 . \varepsilon$ & 0. & 0.52 & 0.72 & 0.59 & 0.7 & 0.6 & 0.6 & & 0. & & 0.6 & & & 0.70 \\
\hline $\mathrm{Q}$ & 21.07 & 14.78 & 14.89 & & 14.14 & 14.99 & 10.27 & 15.77 & 14.90 & 16.7 & 15.1 & 32.74 & 29.39 & 19.48 & 36.90 & 26.23 & 28.84 & 41.1 & 36.7 & 35. & 41. & 32. & & & 32.58 \\
\hline C & 2.75 & & 0.00 & & 0.34 & 0.00 & 0.00 & 0.58 & 0.00 & 0.0 & & 0.56 & 1.77 & 1.60 & 2.4 & 0.49 & 1.41 & 1.3 & 2.2 & & & & & & 0.35 \\
\hline Or & 35.04 & 36.05 & 35.57 & 66.00 & 40.77 & 38.82 & 41.13 & 39.00 & 36.99 & 35.69 & 47.1 & 32.85 & 21.57 & 50.46 & 33.39 & 45.1 & 36.81 & 25.53 & 21.98 & 28. & 21. & 33. & & & 28.66 \\
\hline $\mathrm{Ab}$ & 23.61 & 34.01 & 34 & & 30.46 & 31.64 & 33.25 & 30.38 & 33.08 & 33.51 & 25.5 & 21.74 & 18.87 & 9.90 & & 11.1 & 12.69 & 13.03 & 16.16 & 11. & & 11. & & & 17.51 \\
\hline An & & & & & & & & & & & & & 14. & & & & & & & & & & & & 9.00 \\
\hline $\mathrm{Di}$ & & & & & & & & & & & & & & & & & & & & & & & & & 0.00 \\
\hline Ed & & & & & 0.00 & & & & & & & & & & & & & & & & & & & & .00 \\
\hline SI & & & & & & & & & & & & & & & & & & & & & & & & & .00 \\
\hline En & & & & & & & & & & & & & & & & & & & & & & & & & .99 \\
\hline Fs & & & & & 4. & & & & & & & & & 12 & & & & 44 & & & & & & & 2.74 \\
\hline Hy & & & & & 5.3 & & & 5.6 & 5. & & & & & & & & & & & & & & & & 5.73 \\
\hline Mt & & & & & & & & & & & & & & & & & & & & & & & & & 0.38 \\
\hline 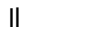 & & & & & & & & & & & & & & & & & & & & & & & & & 0.40 \\
\hline$A p$ & & & & & & & & & 0.21 & & & 0.44 & 0.14 & 0.14 & & 0.19 & 9.00 & 0.12 & & 0.14 & 0.35 & 0.14 & & & 0.25 \\
\hline D.I. & & & & & 85.38 & 85.4 & & & 84.97 & & & & & 79.84 & & 82.55 & 78.34 & & & & & & & & 78.75 \\
\hline SAL & 88.56 & 901.00 & 90 & & 91.4 & 89.9 & 89.84 & 90.31 & 90.98 & 89.75 & & & 85.69 & 88.69 & 89.7 & 90.35 & 87.48 & 88.89 & 86.42 & 88.20 & 87.51 & 36 & 86.45 & 88.67 & 88.11 \\
\hline FEM & & & & & & & & & & & & & & 7.78 & & 7.16 & & & & & & & & & 6.75 \\
\hline V & 38.3 & 21 & 28 & 30.9 & 30.3 & 22.5 & 29.2 & 22.2 & 27.8 & 22. & 12. & 32.0 & 50.4 & 46.8 & 30.9 & 31.6 & 51.2 & 49.6 & 28.7 & 45.3 & 44.3 & 39.0 & 41.6 & 29.4 & 26.0 \\
\hline $\mathrm{Ni}$ & 2 & 3 & & n.d. & 5 & 3.4 & & 6. & & & & & 2 & & 6 & & 7. & & 4 & & & & & & 5.0 \\
\hline $\mathrm{Zn}$ & 43.3 & & & 28.9 & 69.5 & 71 & 70 & 61.7 & 68.0 & & 30 & & 42 & 51.7 & 41.4 & 49.2 & 57.7 & & 43.1 & 45.4 & 31 & 44.1 & 37.5 & 40.5 & 32.8 \\
\hline $\mathrm{Rb}$ & 176 & & & 204 & & & & & 254 & 244 & & & & & & & & & & & 84.9 & & & & \\
\hline $\mathrm{Sr}$ & 13 & & & & & & & & & & & & & & & & & 487 & 13 & & & & & & \\
\hline $\mathrm{Ba}$ & 43 & & & & & & & & & & & 43 & & & & & & 63 & & & 991 & & 1130 & & 479 \\
\hline $\mathrm{Zr}$ & 170 & & & & & & 271 & 294 & & & 30 & 184 & 16 & 21 & 210 & 203 & 110 & & 159 & 99.9 & 66.9 & 10 & 90 & 108 & 96.6 \\
\hline $\mathrm{Pb}$ & 15.0 & 29.5 & & 19.8 & & & 29.2 & n.d. & 27.3 & & 30.1 & n.d. & 19.7 & 23.2 & n.d. & n.d. & 19.7 & 26.7 & 29.3 & 19.5 & 12.8 & 17.8 & 10.7 & 22.3 & 37.0 \\
\hline $\mathrm{Nb}$ & 9.3 & & & 8 & & & & 15.8 & & & & 7.9 & 7.0 & & 10.4 & 11.2 & 7.1 & 3.2 & 8. & 4. & n.d. & 3.8 & 4.6 & 4.1 & 4.9 \\
\hline Y & 32.2 & 54.1 & 46.4 & 32.2 & 39.4 & 41.4 & 33. & 34.8 & 34.0 & 37. & 30 & 19.4 & 16.4 & 17.9 & 21 & 18 & 13.4 & 5.8 & 11.5 & 12.2 & 10.5 & 21.0 & 14.0 & 17.2 & 12.7 \\
\hline La & & 44.2 & & & & & 29 & & & & & & & & & & 20 & 21 & 19 & 36. & 19 & 19.6 & 29.8 & 22.7 & 21.0 \\
\hline $\mathrm{Ce}$ & 75.9 & 69.5 & 91.9 & 47.2 & 72.2 & 76.8 & 56.9 & 53.4 & 75.8 & 67.5 & 60.2 & 42.8 & 37.5 & 28.2 & 44.8 & 59.2 & 26.0 & 30.0 & 36.7 & 32.9 & 34.0 & 46.7 & 46.5 & 42.4 & 33.7 \\
\hline
\end{tabular}

Major element data expressed in wt\%, trace element data expressed in ppm. CIPW norm calculated setting $\mathrm{Fe}_{2} \mathrm{O}_{3} / \mathrm{FeO} w t \%=0.15$. Abbreviations as in Table 5 . 


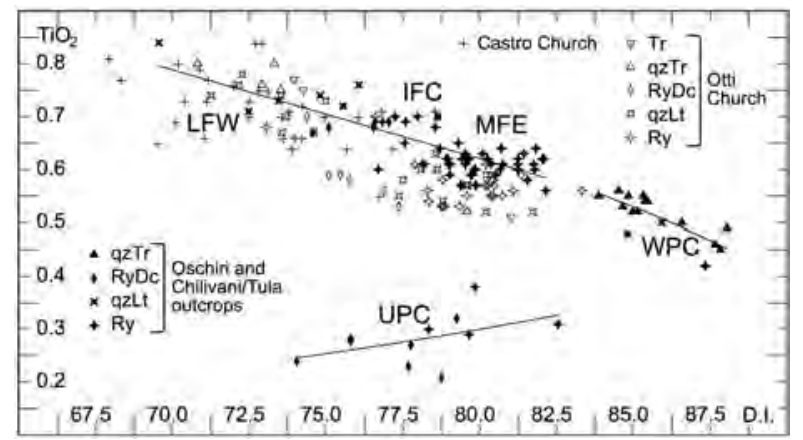

Figure 9. D.I. versus $\mathrm{TiO}_{2}$ diagram for the Oschiri-Chilivani/Tula sectors (only $\mathrm{A}^{-}$unaltered samples) with distinct sample populations from the LFW, IFC, MFE areas from Oschiri sector, and WPC and UPC areas from Chilivani/Tula sector. Graphic symbols: crosses $=$ Castro Church samples; empty symbols $=$ Otti Church samples; black filled-in symbols=outcrop samples of Oschiri and Chilivani/Tula sectors. The symbols of two churches and outcrop samples are differentiated according to the classification $R_{1}$ vs. $R_{2}$ diagram of De La Roche et al. (1980). Abbreviations: $\mathrm{Tr}=$ trachyte; qzTr=quartz-trachyte; RyDc = rhyodacite; qzLt = quartz-latite; Ry = rhyolite. Data from this work, Macciotta et al. (2001) and Columbu (2017).

presence of typical structures (according to Lofgren (1971), sometimes represented by spherulites made up of radially-arranged acicular crystals.

Due to incipient oxidation, in the more altered samples of the Church of Nostra Signora di Castro, as well as in LFW, IFC and MFE samples, the microphenocrystals of opaque granules have a cribriform structure, with consequent formation of secondary hematite and precipitation of iron hydroxides.

By SEM analysis, the groundmass glass is confirmed to be largely devitrified (Figure 10). EDX microanalysis shows that the cryptocrystalline assemblage mainly consists of K-feldspar and quartz. Occasionally, millimetric lithophysaes are also present, often filled by secondary K-feldspars and Fe-rich phyllosilicates. Within the intra-matrix porosity of the volcanic lithofacies with greenish chromatic features, there are finegrained mica-like minerals, and occasionally microcrystalline calcite is also present.

XRD analyses, carried out on samples from the Church of Nostra Signora di Castro and from the outcrops, indicate that the primary mineralogy consists of plagioclases, K-feldspars, quartz, clinopyroxene, orthopyroxene, biotite, and the presence of hematite as a secondary mineral phase. According to features observed in thin section, there is also the presence of subordinate phyllosilicates. XRD analysis on $<2 \mu \mathrm{m}$ oriented mounts shows the presence of smectite and mica-like minerals (i.e. celadonite and glauconite) in the greenish samples, characterising the patches with a more intensive greenish colour. Instead, these minerals have not been found in the reddish samples. Moreover, the occasional presence of cristobalite, tridymite, and zeolite (i.e. mordenite) was found.
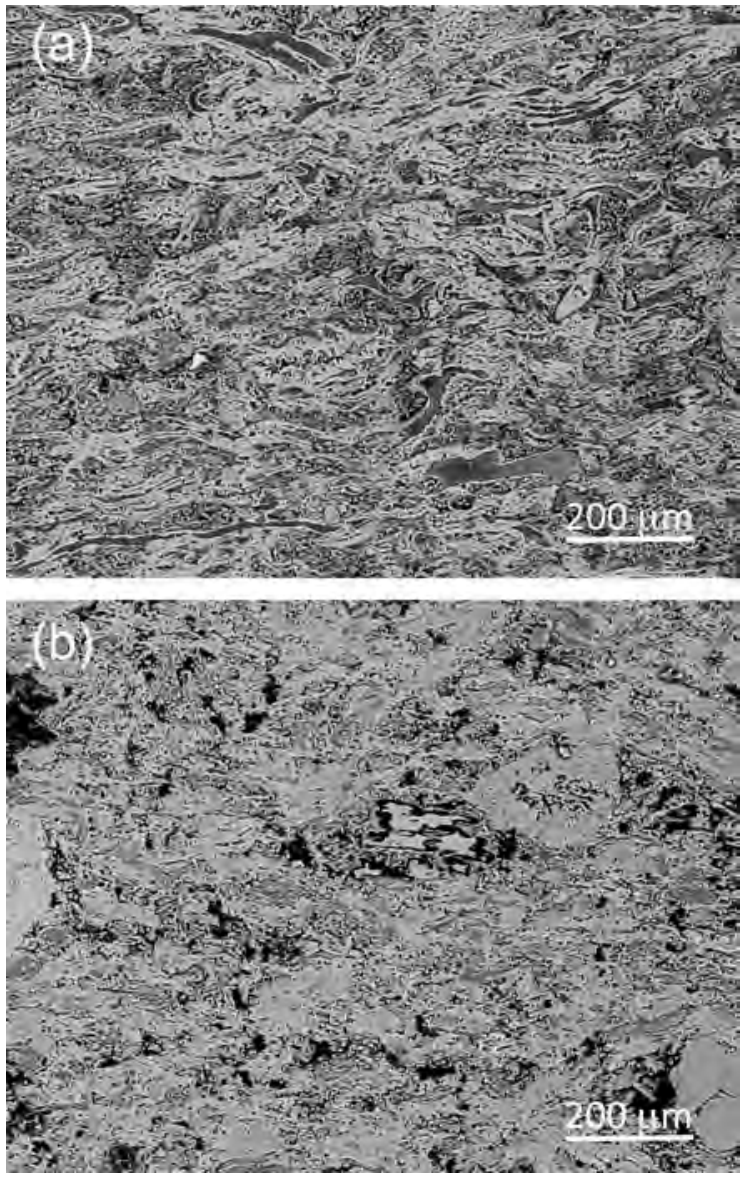

Figure 10. Scanning electron microscope images (backscattered electrons) of the samples coming from the Castro Church, showing the devitrified volcanic ash clasts in the ignimbrite.

By SEM analysis of the specimens $\mathrm{A}^{+}$taken from the Church of Nostra Signora di Castro, abundant whitish encrustations are observed on the exposed surface of the ashlars (Figure 11), possibly induced by a combination of epilithic lichens and moss.

As highligthed by EDX compositional spectrum (Figure 11), the encrustations mainly constist of Carich phase, possibly Ca-oxalates produced by lichens and moss.

\section{Chemical data interpretation}

A total of 32 samples were interpreted considering the chemical composition of the $A^{-}$('fresh' rock) and $A^{+}$ (surface rock) portions of the material. Due to chemical changes linked to sporadic events (e.g. anthropic activity), some samples were not considered in the diagrams. Some trace elements (i.e. $\mathrm{Cr}$ and $\mathrm{Pb}$ ) were excluded from all subsequent consideration because the contents are below the detection limit (or non-calculable dispersion).

The analytical values $\left(A^{-}, A^{+}\right)$of major and trace elements were reported in the binary diagrams of Figures 12 and 13, where the linear straight continuous line (with $y=x$ and $R^{2}=1$ ) and linear regression line of the samples (with an intercept equal to zero) are 

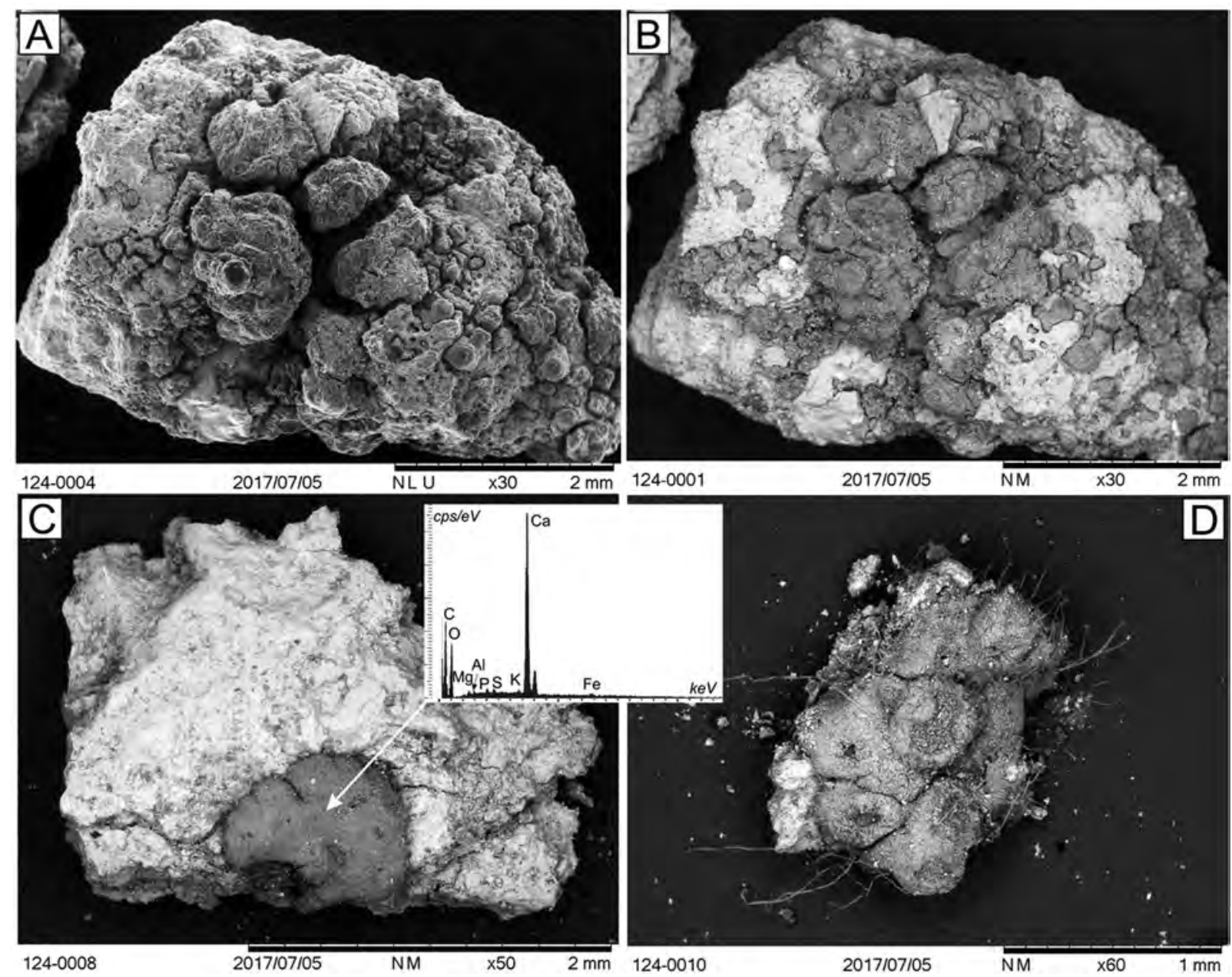

Figure 11. Scanning electron microscope images of the surface of the stone ashlars from the Castro Church, which was exposed to atmospheric agents of deterioration. A, B: secondary (A) and back-scattered electrons (B) images of the same fragment, showing the presence of encrustations on the silicatic substrate; $C$ : back-scattered electrons image of a Ca-bearing mineral neoformation (Caoxalate, Ca-carbonate?) on the silicatic substrate; D: Ca-bearing mineral neoformation with structures suggesting biological features.

reported. Three main theoretical geochemical behaviours can have occurred during the alteration process: (1) the element does not vary (with sample points along the straight bisecting line passing through the origin of the axes); (2) the element decreases in the outer portion $\mathrm{A}^{+}$(with points under the bisecting line); or (3) the element increases in the outer portion $\mathrm{A}^{+}$(with points above the bisecting line). To get useful graphical information from these diagrams on chemical modifications, it would be enough to observe the imbalances of the sample population with respect to the bisecting line, or the position of the regression dashed line (under or upper to the straight bisecting line in the diagrams) passing in the origin of axes.

Considering the major elements (Figure 12), a decrease of concentration values in surface samples $\left(\mathrm{A}^{+}\right)$is observed for $\mathrm{SiO}_{2}, \mathrm{TiO}_{2}, \mathrm{Al}_{2} \mathrm{O}_{3}, \mathrm{Na}_{2} \mathrm{O}$, and $\mathrm{K}_{2} \mathrm{O}$, while a clear increase is observed for $\mathrm{FeO}$ (excluding an outlier), $\mathrm{MnO}, \mathrm{CaO}, \mathrm{P}_{2} \mathrm{O}_{5}$, L.O.I., and $\mathrm{MgO}$ concentrations do not vary during the alteration process.

In the case of trace elements, a decrease of concentration values in outer samples $\left(\mathrm{A}^{+}\right)$is observed for $\mathrm{V}$ and, subordinately, for $\mathrm{Rb}, \mathrm{Sr}$, and $\mathrm{Ba}$ and a clear increase for $\mathrm{Ni}, \mathrm{Y}$, and $\mathrm{Ce}$.

The behaviour of the various chemical elements is summarised analytically in Tables 7 and 8, where it is possible to compare the regression equations and some statistical parameters (e.g. correlation coefficients, minimum, maximum, mean, standard deviation) of the two data sets $\left(A^{-}\right.$and $\left.A^{+}\right)$for the major (Table 7) and trace (Table 8) elements.

\section{Discussion of results}

\section{Geochemical features and provenance of church stones}

To obtain a definitive geochemical-petrographic characterisation and classification of the hewn ashlars, the macroscopic observations were compared and integrated with microscopic and geochemical ones. According to the diagram of De La Roche et al. (1980) (modified; Figure 7), used as main classification scheme of these pyroclastic rocks, the samples of the 
(a)
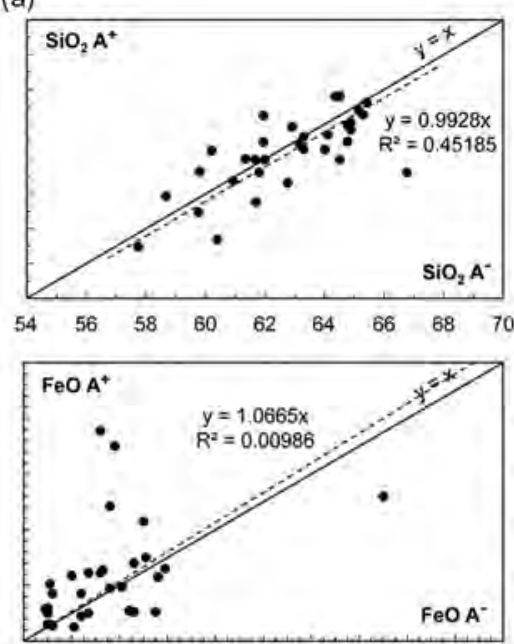

$\begin{array}{lllllllllllll}0.0 & 0.2 & 0.4 & 0.6 & 0.8 & 1.0 & 1.2 & 1.4 & 1.6 & 1.8 & 2.0\end{array}$

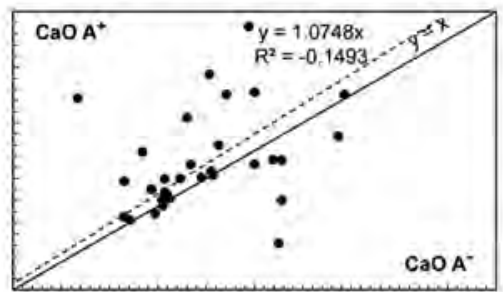

$\begin{array}{lllllllllllll}1.5 & 2.0 & 2.5 & 3.0 & 3.5 & 4.0 & 4.5 & 5.0 & 5.5 & 6.0 & 6.5\end{array}$

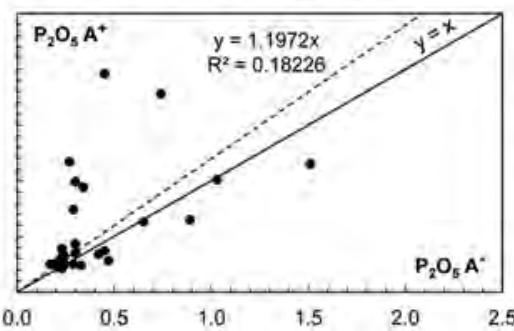

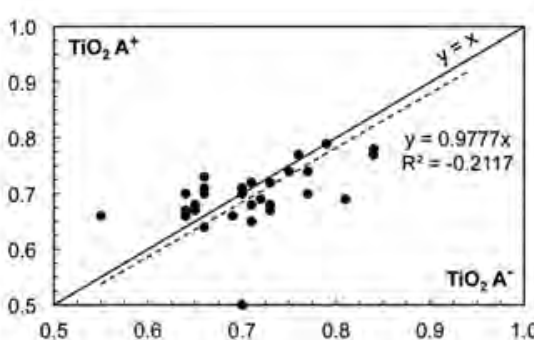
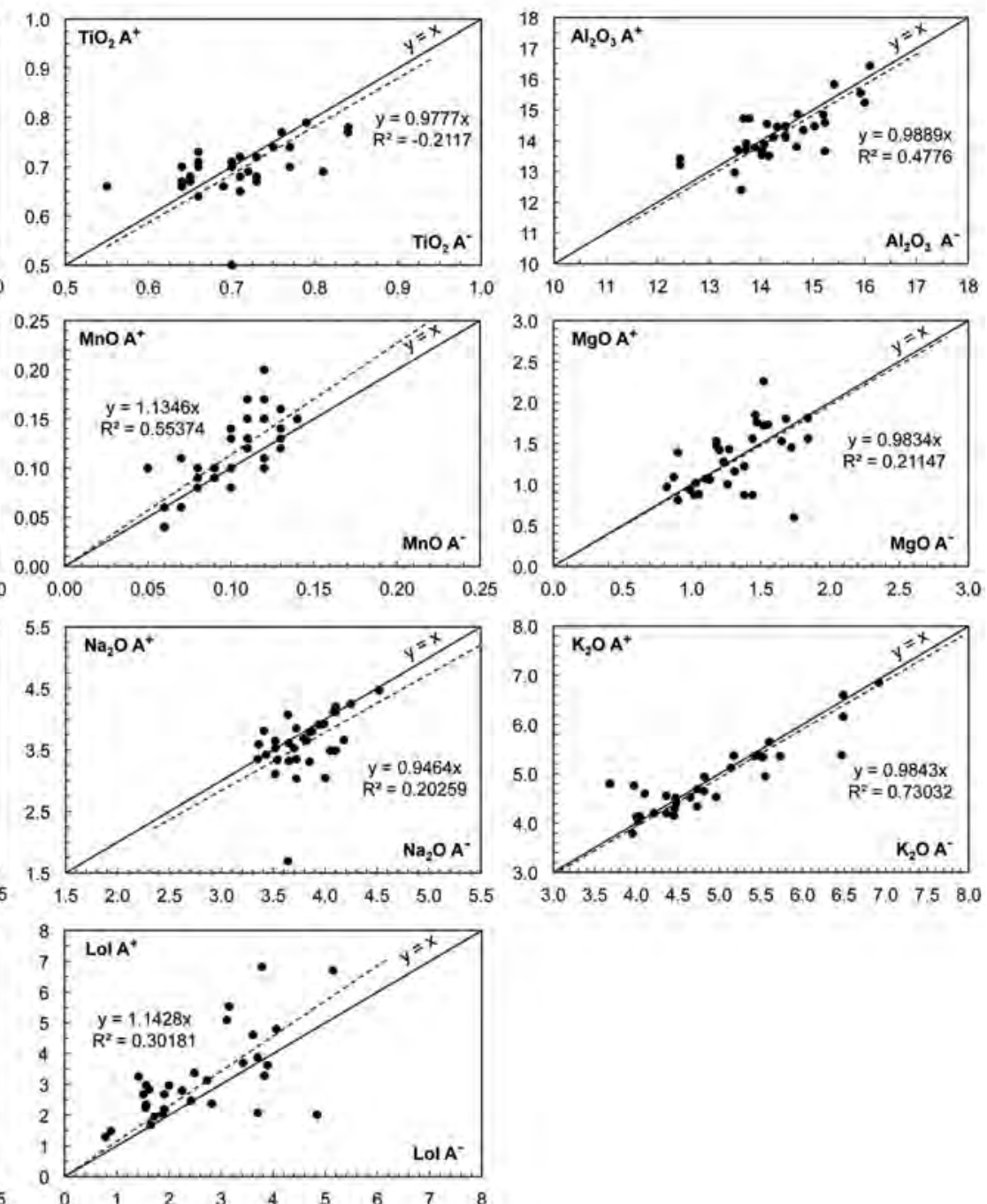

Figure 12. Binary diagrams where reported $A^{+}$vs $A^{-}$concentrations of major elements in samples from the Church. Solid line: $x=y$; dotted line: regression line of samples with intercept at the origin of axes $x, y$.

Church of Nostra Signora di Castro are mainly classified as quartz-latite, rhyodacite, dacite, and rhyolite. That is in agreement with the petrographic features and, also, partly with the classification diagrams of Winchester and Floyd (Figure 8) using some incompatible elements, $\mathrm{Nb}, \mathrm{Y}, \mathrm{Zr}$, that indicate the presence of andesitic rock.

Considering the alteration of these pyroclastics, it is probable that the anomalous andesitic composition of the samples in these classification diagrams is due to leaching of $\mathrm{SiO}_{2}$ (see Figure 12). Moreover, probably the classification of some diagrams of Winchester and Floyd (1977) (Figure 8(a, b)) was also affected by the increase of $Y$ (see Figure 12), which affects a correct interpretation of chemical analysis, moving the classification of these rocks to more basic composition.

In order to define the provenance areas of the hewn stones of monuments, a comparison between the analytical data of samples from the Castro Church, the Otti Church, and volcanic outcrops of the field sectors was made.
The microscopy analysis and the geochemical data show that the stone ashlars used to build the Church of Nostra Signora di Castro have more similar petrographic and geochemical characteristics to the volcanics from Oschiri outcrops than those from the Chilivani/Tula sector.

The most frequently used pyroclastic facies for the ashlars of Castro monument show a petrographic affinity with the volcanics from the western Oschiri subsector (LFW area) and also with a part of pyroclastites used for the nearby Santa Maria di Otti Church (constructed in the same medieval period and similar on the basis of its architectural characteristics). This volcanic facies is characterised by the presence of yellow-ochre pumice lapilli with evident salic phenocrysts and by rare lithics (usually rounded).

Only a subordinate amount of ashlars of the Church of Nostra Signora di Castro resemble volcanics from the central (IFC) and eastern (MFE) areas of Oschiri sector. These latter rocks are characterised by parataxitic to massy vitreous structures, the presence of pumices 
(b)
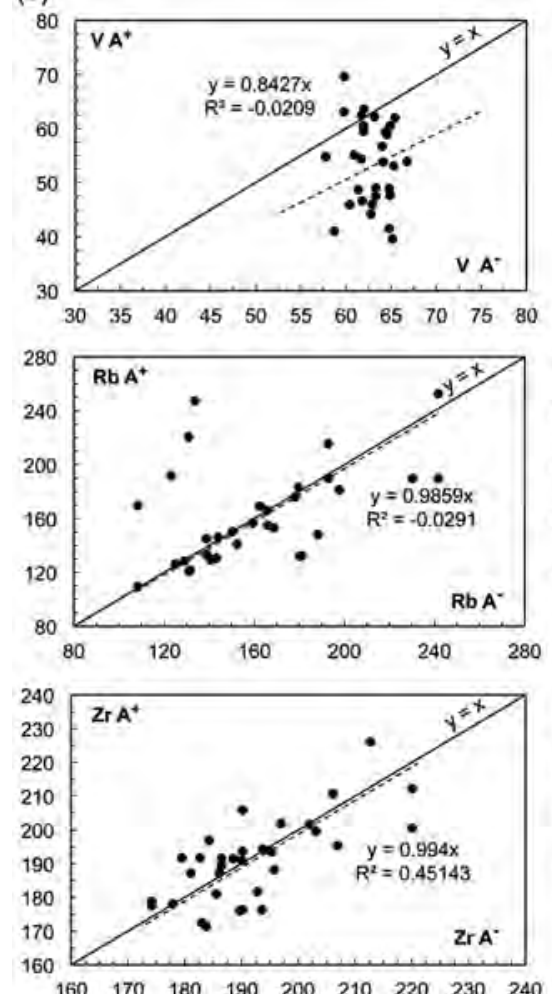

$\begin{array}{llllllll}170 & 180 & 190 & 200 & 210 & 220 & 230 \quad 240\end{array}$

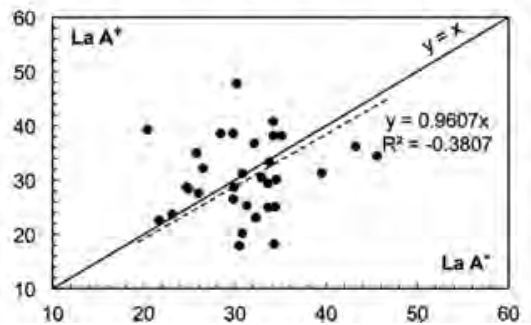

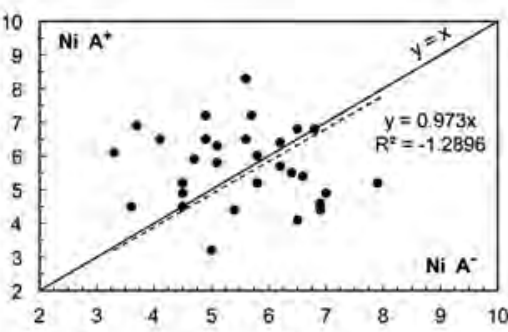
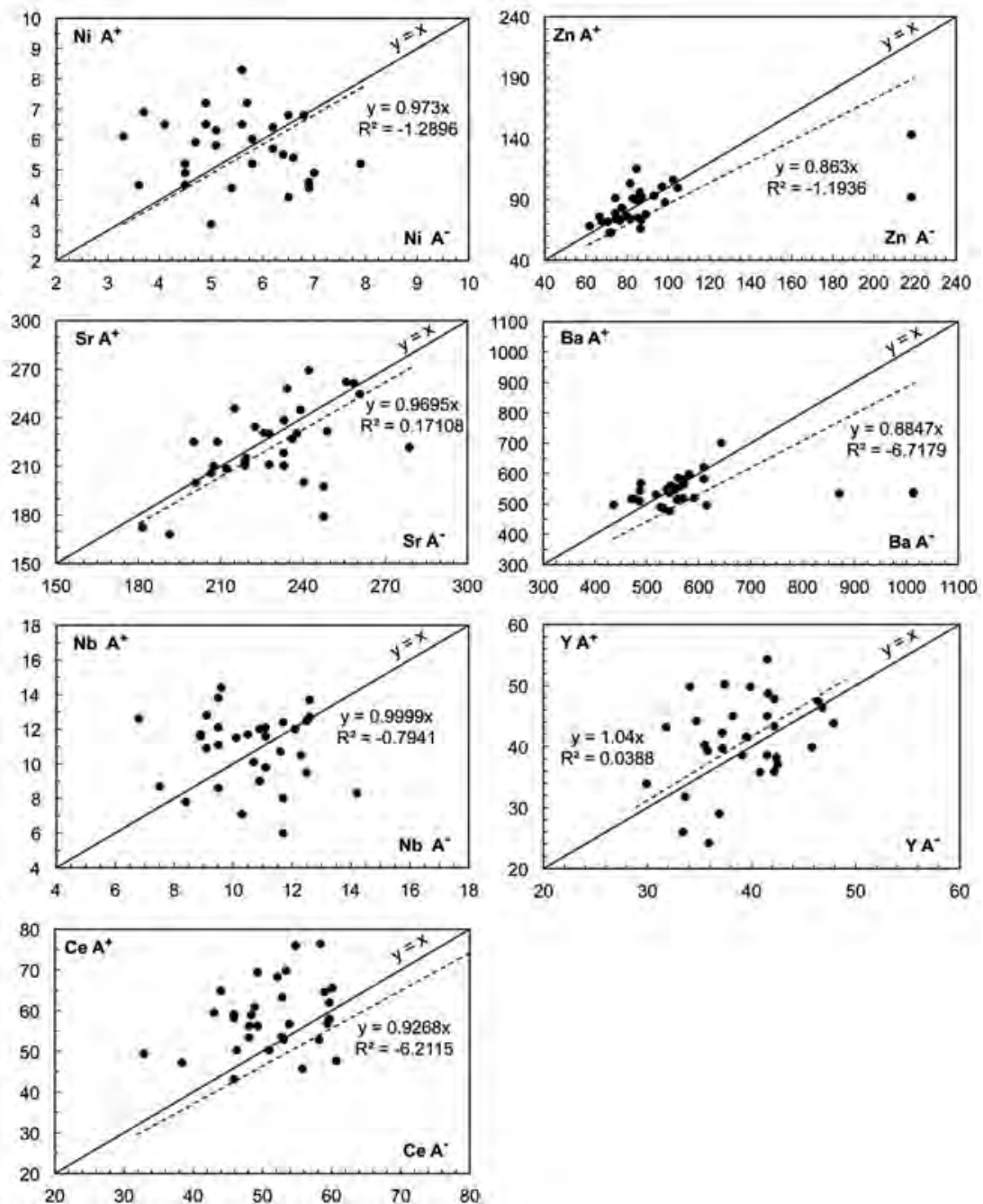

Figure 12. Continued

Table 7. Comparison of regression line equations $(y=a x+b)$ and correlation coefficient data for 32 samples of the Castro Cathedral, using 64 chemical elements concentration data for each sample (\#32 from $A^{-}$inner portion and \#32 from $A^{+}$outer portion) reported in Figures 12 and 13.

\begin{tabular}{|c|c|c|c|c|c|c|}
\hline Var. & $x$ & $y$ & Equation $(*)$ & $R^{2}\left({ }^{*}\right)$ & Equation & $R^{2}$ \\
\hline $\mathrm{SiO}_{2}$ & $A^{-}$ & $\mathrm{A}^{+}$ & $y=0.9928 x$ & 0.45185 & $y=0.7237 x+16.911$ & 0.52444 \\
\hline $\mathrm{TiO}_{2}$ & $A^{-}$ & $\mathrm{A}^{+}$ & $y=0.9777 x$ & -0.2117 & $y=0.41147 x+0.402$ & 0.24691 \\
\hline $\mathrm{Al}_{2} \mathrm{O}_{3}$ & $A^{-}$ & $\mathrm{A}^{+}$ & $y=0.9889 x$ & 0.4776 & $y=0.7099 x+4.0144$ & 0.56518 \\
\hline $\mathrm{FeO}$ & $A^{-}$ & $\mathrm{A}^{+}$ & $y=1.0665 x$ & 0.00986 & $y=0.6017 x+0.2499$ & 0.20292 \\
\hline $\mathrm{MnO}$ & $A^{-}$ & $\mathrm{A}^{+}$ & $y=1.1346 x$ & 0.55374 & $y=1.1631 x-0.003$ & 0.55409 \\
\hline $\mathrm{MgO}$ & $A^{-}$ & $\mathrm{A}^{+}$ & $y=0.9834 x$ & 0.21147 & $y=0.685 x+0.4111$ & 0.26397 \\
\hline $\mathrm{CaO}$ & $A^{-}$ & $\mathrm{A}^{+}$ & $y=1.07448 x$ & -0.1493 & $y=0.4202 x+2.3362$ & 0.09875 \\
\hline $\mathrm{Na}_{2} \mathrm{O}$ & $A^{-}$ & $\mathrm{A}^{+}$ & $y=0.9464 x$ & 0.20259 & $y=0.8012 x+0.5545$ & 0.2095 \\
\hline $\mathrm{K}_{2} \mathrm{O}$ & $A^{-}$ & $\mathrm{A}^{+}$ & $y=0.9843 x$ & 0.73032 & $y=0.7656 x+1.1057$ & 0.79724 \\
\hline $\mathrm{P}_{2} \mathrm{O}_{5}$ & $A^{-}$ & $\mathrm{A}^{+}$ & $y=1.1972 x$ & 0.18226 & $y=0.8192 x+0.2257$ & 0.27124 \\
\hline L.o.l. & $\mathrm{A}^{-}$ & $\mathrm{A}^{+}$ & $y=1.1428 x$ & 0.30181 & $y=0.7808 x+1.119$ & 0.40457 \\
\hline V & $A^{-}$ & $\mathrm{A}^{+}$ & $y=0.8427 x$ & -0.0209 & $y=0.2037 x+40.164$ & 0.002236 \\
\hline $\mathrm{Ni}$ & $\mathrm{A}^{-}$ & $\mathrm{A}^{+}$ & $y=0.973 x$ & -1.2896 & $y=-0.1213 x+6.3058$ & 0.0154 \\
\hline $\mathrm{Zn}$ & $A^{-}$ & $\mathrm{A}^{+}$ & $y=0.863 x$ & -1.1936 & $y=0.2669 x+58.693$ & 0.37758 \\
\hline $\mathrm{Rb}$ & $A^{-}$ & $\mathrm{A}^{+}$ & $y=0.9859 x$ & -0.0291 & $y=0.4831 x+84.729$ & 0.2194 \\
\hline Sr & $A^{-}$ & $\mathrm{A}^{+}$ & $y=0.9695 x$ & 0.17108 & $y=0.6058 x+83.819$ & 0.26884 \\
\hline $\mathrm{Ba}$ & $A^{-}$ & $\mathrm{A}^{+}$ & $y=0.8847 x$ & -6.7179 & $y=0.0437 x+517.64$ & 0.01731 \\
\hline $\mathrm{Zr}$ & $\mathrm{A}^{-}$ & $\mathrm{A}^{+}$ & $y=0.994 x$ & 0.45143 & $y=0.7565 x+45.759$ & 0.50099 \\
\hline $\mathrm{Nb}$ & $A^{-}$ & $\mathrm{A}^{+}$ & $y=0.9999 x$ & 0.7941 & $y=-0.1075 x+11.99$ & 0.00738 \\
\hline Y & $\mathrm{A}^{-}$ & $\mathrm{A}^{+}$ & $y=1.04 x$ & 0.0388 & $y=0.5684 x+18.724$ & 0.12802 \\
\hline La & $\mathrm{A}^{-}$ & $\mathrm{A}^{+}$ & $y=0.9607 x$ & 0.3807 & $y=0.1681 x+25.477$ & 0.017737 \\
\hline $\mathrm{Ce}$ & $A^{-}$ & $\mathrm{A}^{+}$ & $y=0.9268 x$ & -6.2115 & $y=-0.0637 x+61.394$ & 0.02277 \\
\hline
\end{tabular}

$\left({ }^{*}\right)$ with intercept equal to zero.

*Data with intercept equal to zero, passing at the origin of axes $x, y$. Abbreviations: $R^{2}=$ goodness of fit; $R=$ correlation coefficients. 
Table 8. Comparison of statistical parameters (minimum, maximum, mean, standard deviation) for 32 samples of the Castro Cathedral, using the chemical major and trace element concentration data (\#32 from $A^{-}$inner portion and \#32 from $A^{+}$outer portion) reported in Figures 12 and 13.

\begin{tabular}{|c|c|c|c|c|c|c|c|c|c|c|}
\hline Var. & $x$ & Min & Max & Mean & St. Dev. & $y$ & Min & Max & Mean & St. Dev. \\
\hline $\mathrm{SiO}_{2}$ & $A^{-}$ & 57.74 & 66.77 & 62.77 & 2.18 & $A^{+}$ & 56.96 & 65.61 & 62.34 & 2.18 \\
\hline $\mathrm{TiO}_{2}$ & $A^{-}$ & 0.55 & 0.84 & 0.71 & 0.06 & $\mathrm{~A}^{+}$ & 0.50 & 0.79 & 0.70 & 0.05 \\
\hline $\mathrm{Al}_{2} \mathrm{O}_{3}$ & $A^{-}$ & 12.43 & 16.10 & 14.34 & 0.89 & $\mathrm{~A}^{+}$ & 12.40 & 16.43 & 14.19 & 0.84 \\
\hline $\mathrm{FeO}$ & $\mathrm{A}^{-}$ & 0.09 & 1.50 & 0.34 & 0.26 & $\mathrm{~A}^{+}$ & 0.10 & 1.51 & 0.45 & 0.35 \\
\hline $\mathrm{MnO}$ & $\mathrm{A}^{-}$ & 0.05 & 0.14 & 0.10 & 0.02 & $\mathrm{~A}^{+}$ & 0.04 & 0.20 & 0.11 & 0.04 \\
\hline $\mathrm{MgO}$ & $A^{-}$ & 0.82 & 1.84 & 1.31 & 0.29 & $\mathrm{~A}^{+}$ & 0.60 & 2.26 & 1.31 & 0.39 \\
\hline $\mathrm{CaO}$ & $\mathrm{A}^{-}$ & 2.17 & 4.93 & 3.45 & 0.65 & $\mathrm{~A}^{+}$ & 2.34 & 6.23 & 3.79 & 0.88 \\
\hline $\mathrm{Na}_{2} \mathrm{O}$ & $A^{-}$ & 3.35 & 4.52 & 3.80 & 0.28 & $\mathrm{~A}^{+}$ & 1.69 & 4.47 & 3.60 & 0.50 \\
\hline $\mathrm{K}_{2} \mathrm{O}$ & $A^{-}$ & 3.68 & 6.92 & 4.91 & 0.85 & $\mathrm{~A}^{+}$ & 3.79 & 6.85 & 4.87 & 0.73 \\
\hline $\mathrm{P}_{2} \mathrm{O}_{5}$ & $A^{-}$ & 0.17 & 1.51 & 0.39 & 0.29 & $\mathrm{~A}^{+}$ & 0.21 & 1.96 & 0.54 & 0.46 \\
\hline L.o.I. & $A^{-}$ & 0.78 & 5.15 & 2.62 & 1.13 & $\mathrm{~A}^{+}$ & 1.29 & 6.82 & 3.16 & 1.39 \\
\hline V & $\mathrm{A}^{-}$ & 33.10 & 94.10 & 53.65 & 11.84 & $\mathrm{~A}^{+}$ & 25.20 & 69.60 & 52.95 & 9.15 \\
\hline $\mathrm{Ni}$ & $A^{-}$ & 3.30 & 7.90 & 5.53 & 1.14 & $\mathrm{~A}^{+}$ & 3.20 & 8.30 & 5.63 & 1.12 \\
\hline $\mathrm{Zn}$ & $A^{-}$ & 61.90 & 218.30 & 90.59 & 34.99 & $\mathrm{~A}^{+}$ & 62.70 & 143.10 & 85.59 & 16.90 \\
\hline $\mathrm{Rb}$ & $\mathrm{A}^{-}$ & 108.40 & 241.60 & 161.11 & 35.15 & $\mathrm{~A}^{+}$ & 109.60 & 252.60 & 162.57 & 36.25 \\
\hline Sr & $A^{-}$ & 181.50 & 278.80 & 228.48 & 21.46 & $\mathrm{~A}^{+}$ & 168.10 & 269.30 & 222.23 & 25.07 \\
\hline $\mathrm{Ba}$ & $A^{-}$ & 435.50 & 1013.50 & 585.88 & 133.80 & $\mathrm{~A}^{+}$ & 476.60 & 700.60 & 543.25 & 44.44 \\
\hline $\mathrm{Zr}$ & $A^{-}$ & 174.20 & 220.00 & 191.98 & 11.73 & $\mathrm{~A}^{+}$ & 171.50 & 226.10 & 190.99 & 12.53 \\
\hline $\mathrm{Nb}$ & $\mathrm{A}^{-}$ & 6.80 & 14.20 & 10.58 & 1.65 & $\mathrm{~A}^{+}$ & 6.00 & 14.40 & 10.85 & 2.06 \\
\hline Y & $\mathrm{A}^{-}$ & 29.90 & 47.90 & 39.22 & 4.43 & $\mathrm{~A}^{+}$ & 24.20 & 54.30 & 41.02 & 7.04 \\
\hline La & $\mathrm{A}^{-}$ & 20.40 & 45.60 & 31.18 & 5.55 & $\mathrm{~A}^{+}$ & 17.90 & 47.80 & 30.72 & 7.08 \\
\hline $\mathrm{Ce}$ & $A^{-}$ & 32.90 & 159.90 & 54.67 & 20.32 & $\mathrm{~A}^{+}$ & 43.20 & 76.40 & 57.91 & 8.58 \\
\hline
\end{tabular}

varying in colour from green (Figure 4) to yellow-green. The latter facies have a greater abundance of sharpedged (only slightly rounded) lithics with most common size $\sim 5-6 \mathrm{~mm}$. Phenocrystals of sialic minerals (Figure 4) are clearly visible to the naked eye. The visible mafic crystals have always very small size $(<1 \mathrm{~mm})$ and they are rare (or absent).

Using as discriminating markers the differentiation index (D.I.) and $\mathrm{TiO}_{2}$ data (plotted in the diagram of Figure 9), the samples belong mainly from the western area (LFW), subordinately from the central area (IFC) and rarely from the eastern area (MFE). Differently from the case of Church of Nostra Signora di Castro, according to the results of the stepwise linear discriminant analysis and canonical analysis (Columbu 2017) elaborated on the basis of 55 chemical analyses of geological samples ( $A^{-}$type), the similar volcanics of Santa Maria di Otti Church derive mainly from the eastern area (MFE, closer to the monument) of Oschiri sector and subordinately from the western area (LFW). Only one sample comes from the IFC central area.

Thus, considering that on the hill immediately to the west of the Church of Nostra Signora di Castro, but within the Chilivani/Tula sector, pyroclastic rocks outcrop having valid features as construction materials and easier to quarry due to their orientation, probably the ancient territorial subdivisions at those time (based on property or administrative boundaries) affected the choice of supply sites, regardless of distance. It can, therefore, be assumed that the choice of geomaterials was linked mainly to the questions of territorial jurisdiction between the Dioceses of San Antioco di Bisarcio, located further west, and the Curatoria of Nostra Signora di Castro (Figure 4).

\section{Chemical-mineralogical transformations and physical decay}

In general, the ignimbritic rocks of Church of Nostra Signora di Castro show a decay degree that mainly derives from sin- and epi-genetic alteration before the extraction of rocks (e.g. halmyrolysis processes) (Ghiara et al. 1997; Cappelletti, Langella, and Cruciani 1999; Morbidelli et al. 1999; de Gennaro et al. 2000; Cerri and Oggiano 2002; Steindlberger 2004). In agreement with Columbu et al. (2014), the results of XRD analysis show the presence of smectite and mica-like minerals, as well as celadonite and glauconite, which characterise the green patches. SEM-EDX analysis shows the presence of devitrified glasses in a groundmass of rock and the formation of phyllosilicates with variable chemical composition, confirming the halmyrolytic alteration in the volcanic deposit during the sin-epigenetic processes.

Occasional zeolite, tridymite, and cristobalite were found. The zeolite is only present as mordenite, while the clinoptilolite is absent, contrary to what has been observed by other authors (Ghiara et al. 1997; Cappelletti, Langella, and Cruciani 1999; dè Gennaro et al. 2000) in other sectors of Sardinia.

However, processes that occurred in the monument after the laying of minerals also affected the volcanic rocks from a chemical-mineralogical point of view. These processes are mainly concentrated on the stone surface of monuments, with chemical changes between rock substrate $\left(A^{-}\right)$and surface $\left(A^{+}\right)$, and with occasional formation of depositions with very small amounts of different secondary phases (e.g. gypsum, Ca-carbonate).

Considering the chemical data of both $\mathrm{A}^{-}$and $\mathrm{A}^{+}$ portions of the material taken from the Church of 
Nostra Signora di Castro (Table 2), in agreement with results of Columbu (2017), $\mathrm{SiO}_{2}, \mathrm{Na}_{2} \mathrm{O}$, and $\mathrm{K}_{2} \mathrm{O}$ elements decrease during the alteration (Figure 12), showing a leaching process of the matrix on the surface of the stone.

In contrast, data relative to $\mathrm{CaO}, \mathrm{FeO}_{\mathrm{T}}, \mathrm{P}_{2} \mathrm{O}_{5}$, and L.O.I. (Figure 12) show greater enrichment in the $A^{+}$ fraction as compared to the $A^{-}$one. On the basis of XRD analyses, $\mathrm{CaO}$ enrichment cannot be explained by the habit of whitewashing the walls of churches with milk of lime. Analyses carried out on samples covered with organic material (i.e. guano) taken from the outer walls support the hypothesis that high $\mathrm{P}_{2} \mathrm{O}_{5}$ values derive from that source.

The increase of L.O.I. determined at $1000^{\circ} \mathrm{C}$ highlights a clear alteration at the surface of the volcanic rocks, due to a great weight loss for dehydration (with $T<400^{\circ} \mathrm{C}$ ) and dehydroxylation $\left(>400^{\circ} \mathrm{C}\right)$ of the hygroscopic minerals (i.e. smectite and phyllosilicate group, zeolite) more present in the outer $\mathrm{A}^{+}$portion of stone with respect to the inner $A$ portion.

The great enrichment in $\mathrm{FeO}_{\mathrm{T}}$ in $\mathrm{A}^{+}$is related to the weathering that mobilises iron by destabilising Febearing minerals, with the precipitation of hematite and stable Fe-hydroxides and the contemporaneous mobilisation of other elements.

In a chemico-physical point of view, the decay of the ignimbritic rocks from the Church of Nostra Signora di Castro, similarly to the case of the nearby church of Santa Maria di Otti (Columbu et al. 2014), is due to two main coexisting processes: (1) precipitation and cyclic hydration/dehydration of secondary hygroscopic phases (i.e. phyllosilicate, gypsum, zeolite, and soluble salts coming from the soil and/or mortars); and (2) thermal and hydric dilatation, as a function of exposition to weathering. These processes are concentrated especially at the base or in proximity to the covering of the Church of Nostra Signora di Castro, where there is circulation of water for capillary rise or percolation, respectively. The decay in these zones leads to a progressive loss of material of the façade with decohesion, exfoliation, and flaking, which determine a retraction of the outer surface of the ashlars (Figure 2) and a progressive obliteration of the decorative elements.

In agreement with various authors (e.g. Salvadori and Municchia (2016), the presence of biodeteriogens (especially on the north facades of the Church of Nostra Signora di Castro) affects the decay of the ignimbritic rocks accelerating the chemical-physical processes, although according to Özvan et al. (2015), in some cases the biological films have instead a protective action of the stone against alteration processes.

The lichens/moss produce encrustations mainly consisting of probable Ca-oxalates coming from their metabolic activity that fix them on the stone surface. In fact, according to Salvadori and Municchia (2016), the oxalates can form on both carbonatic and silicate rocks. Moreover, the metabolic activity of the same biodeteriogens could influence the chemical transformations of the rock surface, contributing to the smoothing process of some chemical elements in the altered external portion $\left(\mathrm{A}^{+}\right)$of the samples.

\section{Conclusions}

The stones of the old Nostra Signora di Castro Cathedral (Figures 2 and 3) are ignimbrite volcanics belonging to the high- $\mathrm{K}$ calcalkaline (to shoshonitic) series of Miocene volcanic deposits of Eastern Logudoro (Figure 1) and outcropping in the Chilivani-Berchidda Basin.

The results highlight that in the Church of Nostra Signora di Castro several pyroclastic facies with different petro-volcanological features (i.e. from low to high welding degree, from eutaxitic to parataxitic to vitreous structures, variable presence of pumice and lithics, from greenish to grey to pinkish to reddish colours) were used for carving the ashlars of the monument. According to the petrographic features observed in thin section and the classification scheme of De La Roche et al. (1980), the analysed samples of the Castro Cathedral can be classified as quartz-latite, rhyodacite, dacite and rhyolite and, subordinately, as quartz-trachyte, trachyte, and trachyandesite.

On a chemical and petrographic basis, the pyroclastic rocks used in the Church of Nostra Signora di Castro come from the Oschiri sector. According to the differentiation index $v s$. $\mathrm{TiO}_{2}$ diagram, most of the samples belong to the western area, where the Less Fractionated pyroclastites crop out (LFW), characterised by a differentiation index range of 70-78, larger sialic phenocrystals compared to mafic minerals, the presence of yellow-ochre pumice, and rarely rounded lithics.

A subordinate part of the monument volcanic rocks comes from the central Oschiri area, where the Internediately Fractionated pyroclastites crop out (IFC, with D.I. =76-79), and only a few samples from eastern Oschiri area, where the More Fractionated pyroclastic rocks crop out (MFE), characterised by a differentation index of 77-82.

Thus, the procurement of materials occurred from several outcrops in which different volcanic facies emerge. This also happened at the nearby Church of Otti, where however, contrary to the case of the Church of Nostra Signora di Castro, most of the vulcanites come from the eastern area (MFE) of the Oschiri sector, and in a subordinate way from the LFW western area, and only rarely from the IFC central area (Columbu 2017).

Considering that on the basis of geochemical and petrographic results in both churches there is no correlation between the distribution of these volcanic facies (fortuitously employed in the monument) and their geographic origin, it seems unlikely that there could 
be more quarries in operation simultaneously in the medieval period or different construction times for the utilisation of material. More probably, the choice of materials was not based on technical aspects related to intrinsic properties, but on factors related to the economic-social and political structure of that precise historical moment (i.e. contracts between private and ecclesiastical structures-diocese, workers, taxes), where the ownership of land and outcrops and especially territorial and administrative boundaries were probably extremely important. The economiclogistical aspects (e.g. road conditions, costs of transport and extraction) seem to have had a subordinate influence.

The pyroclastic rocks of Nostra Signora di Castro Cathedral show evident alteration, both chemical and physical. The first starts with the halmyrolytic alteration that occurred in the volcanic deposit during the singenetic and epigenetic process. The results of SEM-EDX and XRD analyses show an evident devitrification process of glass in groundmass of rock and the formation of phyllosilicates with variable chemical composition, smectite, celadonite, and glauconite, and occasional zeolite (i.e. mordenite).

Then, the chemical and mineralogical transformations continued even after the laying of stones in the Church of Nostra Signora di Castro. The comparison of concentration data of major and trace elements determined in the surface portion $\left(\mathrm{A}^{+}\right)$and the inner one $\left(A^{-}\right)$of samples taken from the Castro Cathedral highlights a leaching process in pyroclastite samples. $\mathrm{SiO}_{2}, \mathrm{Al}_{2} \mathrm{O}_{3}, \mathrm{Na}_{2} \mathrm{O}$, and $\mathrm{K}_{2} \mathrm{O}$ decrease during the alteration process, due to the hydrolysis mainly of silicate phases (feldspars) and subordinately of a glassy matrix of rock. Greater enrichment of $\mathrm{CaO}, \mathrm{FeO}_{\mathrm{t}}, \mathrm{P}_{2} \mathrm{O}_{5}$, and L.O.I. on the surface of the rock is also observed. The $\mathrm{CaO}$ increase in $\mathrm{A}+$ is due to the re-precipitation of Ca-carbonates on the stone surface, resulting from binder leaching/dissolution of ancient based-lime bedding mortars or (more probably) treatments used for preservation or colouring decorations of stone facades. The highest value of phosphorous oxide in the $\mathrm{A}^{+}$rock portion is due to the nitrates contained in the guano of animals (e.g. birds). L.O.I. increase confirms an advanced alteration degree in the stone surface.

Moreover, the presence of biodeteriogens (lichens, mosses, etc.) in the facades addressed to the north contributes to the deterioration of the church's ignimbrites, through the production of secondary compounds on the stone surface based mainly on Ca-oxalates, and through a physical action due to the constant presence of moisture.

The investigations carried out in this research on the pyroclastics of the Nostra Signora di Castro Church have highlighted, on the one hand, identification of the geological outcrops used for the building materials in that medieval epoch, and on the other, they allow to understand how the processes of alteration evolve in this type of volcanic rock. Thus, the results obtained represent a significant technical-scientific base to be taken into account during conservation procedures carried out on the monument, and also offer precise indications where to procure the raw materials for the possible substitutions of the most degraded stone ashlars, using pyroclastic rocks with physicalmechanical characteristics similar to those of the original materials.

\section{Acknowledgments}

Sampling was carried out with the permission of the local Superintendency to the Historical-Architectural Heritage of Sassari and province.

\section{Disclosure statement}

No potential conflict of interest was reported by the authors.

\section{Funding}

The research was supported financially by the funds of the Cagliari University (PRID 2015) and by the Regione Autonoma della Sardegna (L.R. n.7 - 7 August 2007) through the research project entitled: 'Romanesque and territory: the construction materials of the churches of the Judicial Sardinia: new approaches for the enhancement, conservation and restoration' (application code CRP-18095, CUP: F71J11000620002).

\section{ORCID}

Anna Gioncada (D) http://orcid.org/0000-0002-8513-7377

\section{References}

Advokaat, E. L., D. J. J. Van Hinsbergen, M. Maffione, C. G. Langereis, R. L. M. Vissers, A. Cherchi, R. Schroeder, H. Madani, and S. Columbu. 2014. "Eocene Rotation of Sardinia, and the Paleogeography of the Western Mediterranean Region." Earth and Planetary Science Letters 401: 183-195.

Antonelli, F., S. Columbu, M. De Vos Raaijmakers, and M. Andreoli. 2014. "An Archaeometric Contribution to the Study of Ancient Millstones from the Mulargia Area (Sardinia, Italy) Through New Analytical Data on Volcanic raw Material and Archaeological Items from Hellenistic and Roman North Africa." Journal of Archaeological Science 50: 243-261.

Antonelli, F., S. Columbu, M. Lezzerini, and D. Miriello. 2014. "Petrographic Characterization and Provenance Determination of the White Marbles Used in the Roman Sculptures of Forum Sempronii (Fossombrone, Marche, Italy)." Applied Physics A 115: 1033-1040.

Bargossi, G. M., P. Felli, and F. Guerriri. 2002. "Pietra serena. Materia della città." Aida ed., Firenze, pp. 200.

Beccaluva, L., G. Bianchini, C. Bonadiman, M. Coltorti, G. Macciotta, F. Siena, and C. Vaccaro. 2005. "Within-plate Cenozoic Volcanism and Lithospheric Mantle Evolution in 
the Western-central Mediterranean Area." In Elsevier Special Volume, "Crop Project - Deep Seismic Exploration of the Central Mediterranean and Italy", edited by I. Finetti, 641664. Amsterdam: Elsevier.

Beccaluva, L., G. Bianchini, M. Coltorti, F. Siena, and M. Verde. 2005. "Cenozoic Tectono- Magmatic Evolution of the Central-Western Mediterranean: Migration of an ArcInterarc Basin System and Variations in the Mode of Subduction." In Elsevier Special Volume, "Crop ProjectDeep Seismic Exploration of the Central Mediterranean and Italy", edited by I. Finetti, 623-640. Amsterdam: Elsevier.

Beccaluva, L., G. Bianchini, C. Natali, and F. Siena. 2011. "Geodynamic Control on Orogenic and Anorogenic Magmatic Phases in Sardinia and Southern Spain: Inferences for the Cenozoic Evolution of the Western Mediterranean." Lithos 123 (1-4): 218-224.

Beccaluva, L., P. Brotzu, G. Macciotta, L. Morbidelli, G. Serri, and G. Traversa. 1989. "Cainozoic Tectono-Magmatic Evolution and Inferred Mantle Sources in the SardoTyrrenian Area." In The Lithosphere in Italy, edited by A. Boriani, M. Bonafede, G. B. Piccardo, and G. B. Vai, pp. 229-248. Roma. Advances in Earth Science Research. Atti Conv. Acc. Naz. Lincei, No. 80.

Beccaluva, L., L. Civetta, G. Macciotta, and C. A. Ricci. 1985. "Geochronology in Sardinia: Results and Problems." Rendiconti della Società Ialiana. di Mineralogia e Petrologia 40: 57-72.

Benavente, D., G. Cultrone, and M. Gómez-Heras. 2008. "The Combined Influence of Mineralogical, Hygric and Thermal Properties on the Durability of Porous Building Stones." European Journal of Mineralogy 20 (4): 673-685.

Burrus, J. 1984. "Contribution to a Geodynamic Synthesis of the Provençal Basin (North-Western Mediterranean)." Marine Geology 55: 247-269.

Cappelletti, P., A. Langella, and G. Cruciani. 1999. "Crystalchemistry and Synchrotron Rietveld Refinement of Two Different Clinoptilolites From Volcanoclastites of NorthWestern Sardinia." European Journal of Mineralogy 11 (6): 1051-1060.

Carmignani, L., S. Barca, G. Oggiano, I. Pertusati, P. Conti, A. Eltrudis, A. Funedda, and S. Pasci. 1996. "Carta Geologica della Sardegna 1:200.000." Serv Geol d'Italia.

Carminati, E., and C. Doglioni. 2012. "Alps vs. Apennines: The Paradigm of a Tectonically Asymmetric Earth." EarthScience Reviews 112: 67-96.

Cerri, G., and G. Oggiano. 2002. "Le epiclastiti zeolitizzate del Logudoro orientale: un livello guida all'interno della successione vulcano sedimentaria della Sardegna centro settentrionale." Bollettino della Società Geologica Italiana 121 (1): 3-10.

Cherchi, A., N. Mancin, L. Montadert, M. Murru, M. T. Putzu, F. Schiavinotto, and V. Verrubbi. 2008. "The Stratigraphic Response to the Oligo-Miocene Extension in the Western Mediterranean From Observations on the Sardinia Graben System (Italy)." Bulletin de la Societe Geologique de France 179: 267-287.

Cherchi, A., and L. Montadert. 1982. "Oligo-Miocene Rift of Sardinia and the Early History of the Western Mediterranean Basin." Nature 298: 736-739.

Chiarelli, N., D. Miriello, G. Bianchi, G. Fichera, M. Giamello, and I. T. Memmi. 2015. "Characterisation of Ancient Mortars from the S. Niccolò Archaeological Complex in Montieri (Tuscany - Italy)." Construction and Building Materials 96: 442-460.

Columbu, S. 2017. “Provenance and Alteration of Pyroclastic Rocks From the Romanesque Churches of Logudoro (North Sardinia, Italy) Using a Petrographic and
Geochemical Statistical Approach." Applied Physics A Materials Science and Processing 123 (3): 1-28.

Columbu, S., F. Antonelli, and F. Sitzia. 2018. "Origin of Roman Worked Stones From St. Saturno Christian Basilica (South Sardinia, Italy)." Mediterranean Archaeology and Archaeometry 18 (5): 17-36.

Columbu, S., G. Cruciani, D. Fancello, M. Franceschelli, and G. Musumeci. 2015. "Petrophysical Properties of a GraniteProtomylonite-Ultramylonite Sequence: Insight From the Monte Grighini Shear Zone, Central Sardinia, Italy." European Journal of Mineralogy 27 (4): 471-486.

Columbu, S., and A. M. Garau. 2017. "Mineralogical, Petrographic and Chemical Analysis of Geomaterials Used in the Mortars of Roman Nora Theatre (South Sardinia, Italy)." Italian Journal of Geosciences 136: 238-262.

Columbu, S., A. M. Garau, and C. Lugliè. 2018. "Geochemical Characterisation of Pozzolanic Obsidian Glasses Used in the Ancient Mortars of Nora Roman Theatre (Sardinia, Italy): Provenance of Raw Materials and HistoricalArchaeological Implications." Archaeological and Anthropological Sciences. Advance online publication. doi:10.1007/s12520-018-0658-y.

Columbu, S., A. Gioncada, M. Lezzerini, and M. Marchi. 2014. "Hydric Dilatation of Ignimbritic Stones Used in the Church of Santa Maria di Otti (Oschiri, Northern Sardinia, Italy)." Italian Journal of Geosciences 133: 149-160.

Columbu, S., C. Lisci, F. Sitzia, and G. Buccellato. 2017. "Physical-mechanical Consolidation and Protection of Miocenic Limestone Used on Mediterranean Historical Monuments: The Case Study of Pietra Cantone (Southern Sardinia, Italy)." Environmental Earth Sciences 76 (4): 1-29.

Columbu, S., C. Lisci, F. Sitzia, G. Lorenzetti, M. Lezzerini, S. Pagnotta, S. Raneri, et al. 2018. "Mineralogical, Petrographic and Physical-mechanical Study of Roman Construction Materials from the Maritime Theatre of Hadrian's Villa (Rome, Italy)." Measurement 127: 264-276. doi:10.1016/j.measurement.2018.05.103.

Columbu, S., M. Palomba, F. Sitzia, and M. Murgia. 2018. "Geochemical, Mineral-Petrographic and PhysicalMechanical Characterization of Stones and Mortars From the Romanesque Saccargia Basilica (Sardinia, Italy) to Define Their Origin and Alteration." Italian Journal of Geosciences 137: 369-695.

Columbu, S., G. Piras, F. Sitzia, S. Pagnotta, S. Raneri, S. Legnaioli, V. Palleschi, M. Lezzerini, and M. Giamello. 2018. "Petrographic and Mineralogical Characterization of Volcanic Rocks and Surface-Depositions on Romanesque Monuments." Mediterranean Archaeology and Archaeometry 18 (5): 37-63.

Columbu, S., F. Sitzia, and G. Ennas. 2017. "The Ancient Pozzolanic Mortars and Concretes of Heliocaminus Baths in Hadrian's Villa (Tivoli, Italy)." Archaeological and Anthropological Sciences 9: 523-553.

Columbu, S., F. Sitzia, and G. Verdiani. 2015. "Contribution of Petrophysical Analysis and 3D Digital Survey in the Archaeometric Investigations of the Emperor Hadrian's Baths (Tivoli, Italy)." Rendiconti Lincei 26: 455-474.

Columbu, S., and G. Verdiani. 2014. "Digital Survey and Material Analysis Strategies for Documenting, Monitoring and Study the Romanesque Churches in Sardinia, Italy." Lecture Notes in Computer Science, Springer 8740: 446-453.

Coroneo, R. 1993. Architettura romanica dalla metà del Mille al primo '300. Nuoro: llisso.

Coulon, C. 1977. "Le volcanism calco-alcalin cenozoique de Sardaigne, Italie." Unpublished master's thesis. Univesité St. Jerome, Marseille. 
Cruciani, G., A. Dini, M. Franceschelli, M. Puxeddu, and D. Utzeri. 2010. "Metabasite from the Variscan Belt in NE Sardinia, Italy: Within-Plate OIB-Like Melts with Very High $\mathrm{Sr}$ and Low Nd Isotope Ratios." European Journal of Mineralogy 22: 509-523.

dè Gennaro, M., D. Calcaterra, P. Cappelletti, A. Langella, and V. Morra. 2000. "Building Stone and Related Weathering in the Architecture of the Ancient City of Naples." Journal of Cultural Heritage 1 (4): 399-414.

De La Roche, H., J. Leterrier, P. Grandclaude, and M. Marchal. 1980. "A Classification of Volcanic and Plutonic Rocks Using R 1 R 2 -Diagram and Major-Element Analyses - Its Relationships with Current Nomenclature." Chemical Geology 29: 183-210.

Di Benedetto, C., P. Cappelletti, M. Favaro, S. F. Graziano, A. Langella, D. Calcaterra, and A. Colella. 2015. "Porosity as Key Factor in the Durability of Two Historical Building Stones: Neapolitan Yellow Tuff and Vicenza Stone." Engineering Geology 193: 310-319.

Dostal, J., C. Coulon, and C. Dupuy. 1982. "Cainozoic Andesitic Rock of Sardinia (Italy)." In Andesites: Orogenic Andesites and Related Rocks, edited by R. S. Thorpe, 353-370. Chichester: J. Wiley \& Sons.

Franzini, M., L. Leoni, M. Lezzerini, and R. Cardelli. 2007. "Relationships Between Mineralogical Composition, Water Absorption and Hydric Dilatation in the "Macigno" Sandstones From Lunigiana (Massa, Tuscany)." European Journal of Mineralogy 19 (1): 113-123.

Franzini, M., L. Leoni, and M. Saitta. 1972. "A Simple Method to Evaluate the Matrix Effects in X-Ray Fluorescence Analysis." $X$-Ray Spectrometry 1: 151-154.

Gattaceca, J., A. Deino, R. Rizzo, D. S. Jones, B. Henry, B. Beaudoin, and F. Vadeboin. 2007. "Miocene Rotation of Sardinia: New Paleomagnetic and Geochronological Constraints and Geodynamic Implications." Earth and Planetary Science Letters 258: 359-377.

Ghiara, M. R., R. Lonis, C. Petti, E. Franco, S. Luxoro, and G. Balassone. 1997. "The Zeolitization Process of Tertiary Orogenic Ignimbrites From Sardinia (Italy): Distribution and Mining Importance." Periodico Mineralogia 66: 211-229.

Gioncada, A., L. Leoni, M. Lezzerini, and D. Miriello. 2011. "Relationships Between Mineralogical and Textural Factors in Respect to Hydric Dilatation of Some Sandstones and Meta-Sandstones from the Northern Apennine." Italian Journal of Geosciences 130 (3): 394-403.

Giraud, J., H. Bellon, and G. Turco. 1979. L'intrusion microdioritique tertiaire d'Alghero (Sardaigne). Age K/Ar et relation avec le magmatism calco-alcalin sarde. Analogies aves les esterellites de I'Esterel (Var). C. R. Acad. Sci. Paris: 288, 912, Paris.

Irvine, T. N., and W. R. A. Baragar. 1971. "A Guide to the Chemical Classification of the Common Volcanic Rocks." Canadian Journal of Earth Sciences 8: 523-548.

Lecca, L., R. Lonis, S. Luxoro, E. Melis, F. Secchi, and P. Brotzu. 1997. "Oligo-Miocene Volcanic Sequences and Rifting Stages in Sardinia: A Review." Periodico di Mineralogia 66: 7-61.

Le Maitre, R. W., A. Streckeisen, B. Zanettin, M. J. Le Bas, B. Bonin, P. Bateman, G. Bellieni, et al. 2002. Igneous Rocks: A Classification and Glossary of Terms. Recommendations of the International Union of Geological Sciences, Subcommission of the Systematics of Igneous Rocks. Cambridge: Cambridge University Press.

Leoni, L., M. Lezzerini, S. Battaglia, and F. Cavalcante. 2010. "Corrensite and Chlorite-Rich Chl-S Mixed Layers in Sandstones From the'Macigno' Formation (Northwestern Tuscany, Italy)." Clay Minerals 45: 87-106.
Lezzerini, M., F. Antonelli, S. Columbu, R. Gadducci, A. Marradi, D. Miriello, L. Parodi, L. Secchiari, and A. Lazzeri. 2016. "The Documentation and Conservation of the Cultural Heritage: 3D Laser Scanning and Gis Techniques for Thematic Mapping of the Stonework of the Façade of St. Nicholas Church (Pisa, Italy)." International Journal of Architectural Heritage: Conservation, Analysis, and Restoration 10: 9-19.

Lezzerini, M., S. Pagnotta, S. Columbu, and G. Gallello. 2018. "Archaeometric Study of Mortars from the Pisa's Cathedral Square (Italy)." Measurement 126: 322-331.

Lofgren, G. 1971. "Experimentally Produced Devitrification Textures in Natural Rhyolitic Glass." Geological Society of America Bulletin 82: 111-124.

López-Doncel, R., W. Wedekind, R. Dohrmann, and S. Siegesmund. 2013. "Moisture Expansion Associated to Secondary Porosity: An Example of the Loseros Tuff of Guanajuato, Mexico." Environmental Earth Sciences 69: 1189-1201.

Lustrino, M., S. Duggen, and C. L. Rosenberg. 2011. "The Central-Western Mediterranean: Anomalous Igneous Activity in an Anomalous Collisional Tectonic Setting." Earth-Science Reviews 104: 1-40.

Lustrino, M., L. Fedele, L. Melluso, V. Morra, F. Ronga, J. Geldmacher, D. Duggen, et al. 2013. "Origin and Evolution of Cenozoic Magmatism of Sardinia (Italy). A Combined Isotopic ( $\mathrm{Sr}-\mathrm{Nd}-\mathrm{Pb}-\mathrm{O}-\mathrm{Hf}-\mathrm{Os}$ ) and Petrological View." Lithos 180-181: 138-158.

Lustrino, M., V. Morra, L. Fedele, and L. Franciosi. 2009. “Beginning of the Apennine Subduction System in Central Western Mediterranean: Constraints from Cenozoic 'Orogenic' Magmatic Activity of Sardinia, Italy." Tectonics 28: 1-23.

Manzoni, E., F. Casarin, S. Dandria, A. Dusi, M. Giamello, E. Giorgi, F. Gabbrielli, A. Magrini, and F. Randazzo. 2019. "The Medieval Grange of Cuna - Siena (Italy) Interdisciplinary Studies on Masonry Structures." RILEM Bookseries 18: 2350-2358.

Macciotta, G., G. Bertorino, A. M. Caredda, S. Columbu, R. Coroneo, M. Franceschelli, M. Marchi, S. Rescic. 2001. The S.Antioco of Bisarcio Basilica (NE Sardinia, Italy): Waterrock Interaction in Ignimbrite Monument Decay. In Water-Rock Interaction (WRI-10), edited by R. Cidu, vol. 1, 415-418. Lisse: Swets \& Zeitlinger.

Miriello, D., F. Antonelli, C. Apollaro, A. Bloise, N. Bruno, E. Catalano, S. Columbu, et al. 2015. "New Data About the Ancient Mortars from the Archaeological Site of Kyme (Turkey): Compositional Characterization." Periodico di Mineralogia 84 (3A): 497-517.

Montigny, R., J. B. Edel, and R. Thuizat. 1981. “Oligo-miocene Rotation of Sardinia: k-ar Ages and Paleomagnetic Data of Tertiary Volcanics." Earth and Planetary Science Letters 54: 261-271.

Morbidelli, P., M. R. Ghiara, R. Lonis R, and A. Sau. 1999. "Zeolitic Occurrences From Tertiary Pyroclastic Flows and Related Epiclastic Deposits Outcropping in Northern Sardinia (Italy)." Periodico Mineralogia 2: 287-313.

Oggiano, G., S. Pasci, and A. Funedda. 1995. "II bacino di Chilivani- Berchidda: un esempio di struttura transtensiva. Possibili relazioni con la geodinamica cenozoica del Mediterraneo occidentale." Bollettino della Società Geologica Italiana 114: 465-475.

Özvan, A., I. Dinçer, M. Akın, V. Oyan, and Mu. Tapan. 2015. "Experimental Studies on Ignimbrite and the Effect of Lichens and Capillarity on the Deterioration of Seljuk Gravestones." Engineering Geology 185: 81-95.

Peterson, D. W. 1979. "Significance of Flattening of Pumice Fragments in Ash-flow Tuffs." In Ash-Flow Tuffs and 
Associate Igneous Rocks, edited by C.E. Chapin and W. E. Elston. Spec. Pap. Geol. Soc. Am. 180:95-204.

Pioli, L., and M. and Rosi. 2005. "Rheomorphic Structures in a High-Grade Ignimbrite: The Nuraxi Tuff, Sulcis Volcanic District (SW Sardinia, Italy)." Journal of Volcanology and Geothermal Research 142: 11-28.

Quane, S. L., and J. K. Russell. 2005a. "Ranking Welding Intensity in Pyroclastic Deposits." Bulletin of Volcanology, 67 (2): 129-143.

Quane, S. L., and J. K. Russell. 2005b. "Welding: Insights from Hightemperature Analogue Experiments." Journal of Volcanology and Geothermal Research 142: 67-87.

Ragan, D. H., and M. F. Sheridan. 1972. "Compaction of the Bishop Tuff, California." Geological Society of America Bulletin 83: 95-106.

Ramacciotti, M., S. Rubio, G. Gallello, M. Lezzerini, S. Columbu, E. Hernandez, A. Morales-Rubio, A. Pastor, and M. De La Guardia. 2018. "Chronological Classification of Ancient Mortars Employing Spectroscopy and Spectrometry Techniques: Sagunto (Valencia, Spain) Case." Journal of Spectroscopy 2018: 1-10. doi:10.1155/2018/9736547.

Raneri, S., S. Pagnotta, M. Lezzerini, S. Legnaioli, V. Palleschi, S. Columbu, N. F. Neri, and P. Mazzoleni. 2018. "Examining the Reactivity of Volcanic Ash in Ancient Mortars by Using a Micro-chemical Approach." Mediterranean Archaeology and Archaeometry 18 (5): 147-157.

Riehle, J. R. 1973. "Calculated Compaction Profiles of Rhyolitic Ash-flow Tuffs: Computational Model." Bulletin of Volcanology 57: 319-336.

Rodriguez-Navarro, C., E. Hansen, E. Sebastián, and W. S. Ginell. 1997. "The Role of Clays in the Decay of Ancient Egyptian Limestone Sculptures." Journal of the American Institute for Conservation 36: 151-163.

Sabatini, G., M. Giamello, R. Pini, S. Siano, and R. Salimbeni. 2000. "Laser Cleaning Methodologies for Stone Façades and Monuments: Laboratory Analyses on Lithotypes of Siena Architecture." Journal of Cultural Heritage 1 (1): S9S19.

Salvadori, O., and A. C. Municchia. 2016. "The Role of Fungi and Lichens in the Biodeterioration of Stone Monuments." The Open Conference Proceedings Journal 7 (1: M4): 39-54.

Sau, A., L. Lecca, R. Lonis, F. Secchi, and M. L. Fercia. 2005. "La seconda fase del Rift Sardo: vulcanismo ed evoluzione dei subbacini di Ardara-Chilivani e Bonorva (Sardegna settentrionale)." Bollettino della Società Geologica Italiana 124: 3-20.

Savelli, C. 1975. "Datazioni preliminari col metodo K-Ar di vulcaniti della Sardegna sud-occidentale." Rendiconti della Societià Italiana di Mineralogia e Petrologia 31: 191-198.
Savelli, C., L. Beccaluva, M. Deriu, G. Macciotta, and L. Maccioni. 1979. "K/Ar Geochronology and Evolution of the Tertiary "Calc-Alkalic" Volcanism of Sardinia (Italy)." Journal of Volcanology and Geothermal Research 5: 257269.

Sebastian, E., G. Cultrone, D. Benavente, L. L. Fernandez, K. Elert, and C. Rodriguez-Navarro. 2008. "Swelling Damage in Clay-Rich Sandstones Used in the Church of San Mateo in Tarifa (Spain)." Journal of Cultural Heritage 9 (2): 66-76.

Serra, R., and R. Coroneo. 2004. Sardegna Preromanica e Romanica. Milano: Jaca Book, pp. 320.

Shand, S. J. 1951. Eruptive Rocks; Their Genesis, Composition, Classification, and Their Relation to Ore-Deposits, with a Chapter on Meteorites. 4th ed. Wiley: New York.

Smith, R. L. 1960. "Ash Flows." Geological Society of America Bulletin 71: 795-842.

Spano, G. 1858. "Sardegna Sacra e le Antiche Diocesi." Bullettino Archeologico Sardo 4: 41-48.

Sparks, R. S. J., S. R. Tait, and Y. Yanev. 1999. “Dense Welding Caused by Volatile Resorption." Journal of the Geological Society 156: 217-225.

Speranza, F., I. M. Villa, L. Sagnotti, F. Florindo, D. Cosentino, P. Cipollari, and M. Mattei. 2002. "Age of the Corsica-Sardinia Rotation and Liguro-Provençal Basin Spreading: New Paleomagnetic and Ar/Ar Evidence." Tectonophysics 347 (4): 231-251.

Steindlberger, E. 2004. "Volcanic Tuffs From Hesse (Germany) and Their Weathering Behaviour." Environmental Geology 46: 378-390.

Streck, M. J., and A. L. Grunder. 1995. "Crystallization and Welding Variations in a Widespread Ignimbrite Sheet; the Rattlesnake Tuff, Eastern Oregon, USA." Bulletin of Volcanology 57: 151-169.

Thornton, C. P., and O. F. Tuttle. 1960. "Chemistry of Igneous Rocks--[Part] 1, Differentiation Index." American Journal of Science 258: 664-684.

Vardabasso, S., and A. Atzeni. 1962. "Il bacino Oligocenico di Oschiri- Berchidda nella Sardegna nord-occidentale." Memorie della Societa Geologica Italiana 3: 717.

Verdiani, G., and S. Columbu. 2010. "E. Stone, an Archive for the Sardinia Monumental Witnesses." Lecture Notes in Computer Science 6436: 356-372.

Wangler, T., and G. W. Scherer. 2008. "Clay Swelling Mechanism in Clay-Bearing Sandstones." Environmental Geology 56 (3-4): 529-534.

Winchester, J. A., and P. A. Floyd. 1977. "Geochemical Discrimination of Different Magma Series and Their Differentiation Products Using Immobile Elements." Chemical Geology 20: 325-343. 